University of Chicago Law School

Chicago Unbound

Journal Articles

Faculty Scholarship

1993

\title{
Understanding the Limits of Court-Connected ADR: A Critique of Federal Court-Annexed Arbitration Programs
}

Lisa Bernstein

Follow this and additional works at: https://chicagounbound.uchicago.edu/journal_articles

Part of the Law Commons

\section{Recommended Citation}

Lisa Bernstein, "Understanding the Limits of Court-Connected ADR: A Critique of Federal Court-Annexed Arbitration Programs," 141 University of Pennsylvania Law Review 2169 (1993).

This Article is brought to you for free and open access by the Faculty Scholarship at Chicago Unbound. It has been accepted for inclusion in Journal Articles by an authorized administrator of Chicago Unbound. For more information, please contact unbound@law.uchicago.edu. 


\section{University of Pennsylvania \\ Law Review}

FOUNDED 1852

Formerly

American Law Register

\section{ARTICLE}

UNDERSTANDING THE LIMITS OF GOURT-CONNECTED

ADR: A CRITIQUE OF FEDERAL COURT-ANNEXED

ARBITRATION PROGRAMS

LISA BERNSTEIN†

† Associate Professor, Boston University School of Law. B.A. 1986, The University of Chicago; J.D. 1990, Harvard Law School. I would like to thank Steven Shavell, Frank E.A. Sander, Louis Kaplow, Yaakov Khazanov, David Wilkins, Robert Bone, Steve Marks, Robert Merges, Geoffrey Miller, Edward Bernstein, Keith Hylton, Bruce Hay, Kathryn Spier, David Charny, Eric Green, Tamar Frankel, Jesse Fried, Mitchell N. Berman, Sarah Fitts, and participants at the Harvard Law and Economics Workshop, the Stanford Legal Profession Workshop, the Emory Law School Faculty Colloquium, the Boston University Faculty Workshop, the Georgetown University Law Center Law and Economics Workshop, and the ADR panel of the American Law and Economics Association Annual Meetings for helpful comments. I would also like to thank Esther Galiana and Harold Feld for their research assistance and Kim Dulin, Jonathan Fernald, Anne Klinefelter, and Martha Renick for their reference assistance. Special thanks are due to David Chasman for designing and running the simulations. This research was supported by a grant from the John M. Olin Foundation at Harvard Law School and the Boston University Faculty Summer Research Program. 
In this Article, the author argues that mandatory, non-binding federal court-annexed arbitration programs will not succeed in increasing access to justice, and may in fact decrease access to justice for poorer litigants, precisely the people the programs were designed to help. After exploring the effects of such programs on parties' litigation decisions and demonstrating that the programs are unlikely to create private or social benefits, the Article explores the attributes of private ADR tribunals that parties find desirable and the many ways, apart from reducing cost and delay, that private $A D R$ agreements create value. The Article concludes that, while the promise of the court-connected ADR movement for solving the problems facing the federal courts is limited, procedural reform that explicitly permits parties to combine private $A D R$ and traditional adjudication might be desirable.

\section{TABle of ConTentS}

I. The Basic Features of Court-ANNEXED ARbitration Programs . . . . . . . . 2177

II. THE MARKET FOR DISPUTE RESOLUTION AND JUSTIFICATIONS FOR GOVERNMENT

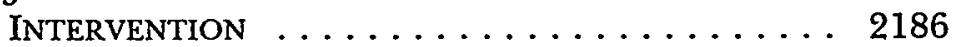

A. The Market for Private ADR Services . . . . . . 2187

B. Barriers to the Voluntary Use of Private ADR . . . . . 2189

1. Legal Restrictions . . . . . . . . . . 2191

2. Signaling . . . . . . . . . . . . 2191

3. Transactions Costs . . . . . . . . . . . . . 2193

4. Asymmetric Ability to Bear the

Costs of Delay .............. 2193

5. Lawyer-Client Conflicts of Interest . . . . . . 2195

6. Unequal Bargaining Power in Tort Claims . . . 2196

C. Justifications for Mandatory Non-Binding

CAA Programs . . . . . . . . . . . . . . 2197

1. Reducing the Number of Nuisance Suits

and Negative Expected Value Suits ...... 2197

a. Asymmetric Cost Theory ... . . . . . . . 2198

i. Programs Without Post-Arbitration

Fee and Cost-Shifting

Provisions ................ 2199

ii. Programs with Post-Arbitration Fee

and Cost-Shifting Provisions . . . . . 2201

iii. Summary . . . . . . . . . . . . . 2201 
b. Cloud on Title Theory ... . . . . . . . . 2203

c. Asymmetric Information Theory . . . . . . . 2205

i. Programs Without Post-Arbitration Fee and Cost-Shifting Provisions . . . . . 2207

ii. Programs with Post-Arbitration Fee and Cost-Shifting Provisions . . . . . 2208

d. Aggregate Effects on the Volume of Nuisance and NEV Suits . . . . . . . . 2210

2. Reducing Cost and Delay ............. 2211 III. THE EFFeCT OF CAA PROGRAMS ON PARTIES'

Litigation Decisions . . . . . . . . . . . 2215

A. The Sequence of Parties' Litigation

Decisions in a CAA Jurisdiction . . . . . . . . 2216

B. Simulations of Parties' Litigation Decisions

in a CAA Jurisdiction . . . . . . . . . . . . . 2219

1. Convergent Expectations . . . . . . . . . 2220

2. Divergent Expectations . . . . . . . . . . . . 2224

a. Mutual Optimism . . . . . . . . . . . . 2224

b. Mutual Pessimism . . . . . . . . . . . . . . 2227

C. Factors Not Taken into Account

in the Simulations . . . . . . . . . . . . . 2228

1. The Cost of the Litigation Process . . . . . . 2228

a. Asymmetric Costs in Small Claims . . . . . . . 2228

b. The Effect of the Programs on Parties'

Litigation Expenditures . . . . . . . 2229

2. The Cost of the Arbitration Hearing . . . . . . 2231

3. The Cost of Civil Discovery . . . . . . . . 2232

4. The Parties' Relative Bargaining Power . . . . . . 2234

a. Risk Aversion ................ 2235

b. Delay .................... 2238

IV. The Differences Between Private AND Public ADR • 2239

A. Features of Private ADR Tribunals . . . . . . . . 2240

1. Secrecy . . . . . . . . . . . . . . . 2240

2. Informality . . . . . . . . . . . . 2241

3. Finality and Reduction of Delay . . . . . . . 2243

4. Consent . . . . . . . . . . . . . . . . . . 2243

5. Summary . . . . . . . . . . . . . . . . 2244

B. Functions of ADR Provisions . . . . . . . . . . . 2244

1. ADR Clauses and the Creation of Value ... . . 2245

2. Advantages of Specialized Providers . . . . . . 2247

3. Broadening the Range of Credible

Substantive Commitments . . . . . . . . 2248 
4. Enforcement Advantages . . . . . . . . . 2248

5. The Potential Uses of Private ADR to

Increase the Value of Traditional

Adjudication ................ 2251

ConCLUSION . . . . . . . . . . . . . . . . . 2253

TECHNICAL APPENDIX $\ldots \ldots \ldots \ldots \ldots \ldots \ldots \ldots \ldots \ldots$

In recent years the availability of private dispute resolution providers, ranging from expert mediators to rent-a-judge programs complete with black robes and model courtrooms, ${ }^{1}$ has increased dramatically. ${ }^{2}$ The alternative dispute resolution ("ADR") movement has received extensive press attention and has been hailed as a solution to crowded dockets and an inexpensive panacea for the ills of an overly litigious society. Pointing to the rapid growth of private ADR providers and studies purporting to show a high level of lawyer and client satisfaction with these alternative processes, states, joined recently by the federal government, began passing laws ${ }^{3}$ requiring parties to participate in an $A D R$ process as a precondition to judicial resolution of their dispute.

In 1978, Congress authorized the creation of the first three federal district court-annexed arbitration programs. ${ }^{4}$ The programs

${ }^{1}$ A private rent-a-judge program is operated by Judicate, a publicly owned company. See infra note 71 (describing Judicate's services). In addition, California operates a quasi-public rent-a-judge program. Parties pay a retired judge to hear their case and issue an opinion which can then be appealed as if a regular trial had been held. See CAL. Crv. PROC. CoDE $§ \S 638-645$ (West 1993). The California program has been criticized on the grounds that it creates a two-tiered system of justice, enabling the rich to get in line for an appellate decision four or five years before the poor even have a trial date. See Judicial Council of CAL., The Report and ReCOMmeNDATIONS OF THE JUdicial COUNCIL AdVISORY CoMmITTEe ON PRIVATE JUdGes 19-20 (1992).

2 See Ellen J. Pollock, Business of Mediating Brings in Big Money, WALL ST. J., Mar. 22,1993 , at B1, B9 (describing the burgeoning caseloads of for-profit ADR providers such as Judicial Arbitration \& Mediation Services, Inc., Endispute, Inc., and Judicate, Inc.).

${ }^{3}$ Throughout the seventies and eighties state legislatures passed ADR legislation at an increasingly rapid rate. In 1980, state legislatures passed fewer than five ADR bills. In 1989, they passed 34 of 140 proposed ADR-related bills. See AMERICAN BAR ASSOC., LEGISLATION ON DISPUTE RESOLUTION 75 (1990). As of 1988, the latest date for which complete data are available, twenty-two states and the District of Columbia operated some type of court-annexed arbitration program for civil claims. See Susan Keilitz et al., State Adoption of Alternative Dispute Resolution: Where is it Today?, STATE CT. J., Spring 1988, at 4, 6.

4 The three districts were the Eastern District of Pennsylvania, the Northern District of California, and the District of Connecticut. The District of Connecticut 
required parties to participate in a mandatory non-binding courtannexed arbitration ("CAA") hearing as a precondition to obtaining a trial. The programs received strong support from then Attorney General Griffin Bell, who believed that compulsory court-annexed arbitration programs would "broaden access for the American people to their justice system and ... provide mechanisms that will permit the expeditious resolution of disputes at a reasonable cost." In 1985 , Congress funded eight additional CAA pilot programs. ${ }^{6}$ In 1988, it authorized continued experimentation with mandatory $\mathrm{CAA}^{7}$ and provided funding for ten voluntary CAA pilot programs. ${ }^{8}$

The trend towards publicly sponsored or mandated ADR shows no signs of abating. ${ }^{9}$ One of the six "cornerstone principles" of the

discontinued its program in 1982, citing disproportionate administrative costs. However, it continues to experiment with other forms of ADR such as "using special masters to facilitate settlement, binding and non-binding mediation and mini-trials, judicially supervised settlement conferences, and summary jury trials." BARBARA S. MEIERHOEFER, FEDERAL JUdicial CTR., COURT-ANNEXEd ARBITRATION IN TEN DISTRICT COURTS 14 n.4 (1990) [hereinafter MEIERHOEFER, CAA IN TEN DIST. CTS.].

5 The Court-Annexed Arbitration Act of 1978: Hearings on S. 2253 Before the Subcomm. on Improvements in Judicial Machinery of the Senate Comm. on the Judiciary, 95th Cong., 2d. Sess 21 (1978) (statement of Griffin B. Bell, Attorney General).

6 See MEIERHOEFER, CAA IN TEN DIST. CTS., supra note 4, at 15.

7 See 28 U.S.C. $\$ 651(a)(1988)$.

8 See id. $\$ 658$.

${ }^{9}$ See James F. Henry, No Longer a Rarity, Judicial ADR is Preparing for Great Growth-But Much Care is Needed, 9 ALTERNATIVES 95, 95 (1991) (reporting that "40 percent of federal district courts and nearly half the circuits have enacted formal ADR rules"); see also John L. Barkai \& Gene Kassebaum, Using Court-Annexed Arbitration to Reduce Litigant Costs and to Increase the Pace of Litigation, 16 PEPP. L. REV. S43, S44 (1989) (arguing that the success of Hawaii's state tort claim CAA program, which has a jurisdictional limit of $\$ 150,000$, demonstrates that an arbitration program need not be limited to low-value civil cases); Raymond J. Broderick, Court-Annexed Compulsory Arbitration: It Works, 72 JUDICATURE 217, 217 (1989) (arguing that the success of the state and federal court-annexed ADR programs suggests that "now is the time to consider making court-annexed compulsory arbitration an integral part of our federal judicial system so that it will become available to all our U.S. [D]istrict [C]ourts"). Recently, the Advisory Committee to the Federal District Court for the District of New Jersey, recommended that the district's CAA program be greatly expanded. See Judicial ADR: Reducing Expenses and Delays, 9 ALTERNATIVES 179, 179 (1991).

The trend toward government-sponsored ADR is not confined to the courts. The Administrative Dispute Resolution Act, Pub. L. No. 101-552, 1990 U.S.C.C.A.N. (104 Stat.) 2736 (codified as amended at 5 U.S.C.A. $\$ \S 581-593$ (West Supp. 1993)), directs each government agency to appoint an ADR coordinator to study the feasibility of using ADR in place of agency adjudication. See 5 U.S.C.A. $\$ 581$ note (West Supp. 1993) (Promotion of Alternative Means of Dispute Resolution). Similarly, a number of recently introduced health care reform bills contain provisions that require certain types of medical malpractice claims to be submitted to publicly administered ADR 
Civil Justice Reform Act of $1990^{10}$ was "expanding and enhancing the use of alternative dispute resolution." 11 The Act directed each federal district court to complete a cost and delay reduction plan and to specifically consider the possibility of instituting courtconnected ADR programs. ${ }^{12}$ As of February 1992, thirty-two of the thirty-four federal courts that had completed these plans either endorsed or adopted some type of court-connected ADR. ${ }^{13}$ In addition, the Federal Courts Study Committee, which was created to "develop a long-range plan for ... the Federal judiciary, including assessments involving ... alternative methods of dispute resolution," 14 recommended that Congress "broaden statutory authorization for local rules for alternative and supplementary procedures in civil litigation, including rules for cost and fee incentives." 15

Despite its widespread acceptance by lawmakers and most legal scholars, ${ }^{16}$ the effects of court-annexed arbitration programs on

programs. See, e.g., H.R. 101, 103d Cong., 1st Sess. $§ 212$ (1993) (stating that "[n]o medical malpractice liability action may be brought in any state court . . . unless the claim . . . has been initially resolved under an alternative dispute resolution system").

${ }^{10}$ Pub. L. No. 101-650, 1990 U.S.C.C.A.N. (104 Stat.) 5089 (codified as amended at 28 U.S.C. $\S \S 471-482$ (Supp. III 1991)).

${ }^{11}$ S. REP. No. 416, 101 st Cong., 1st Sess. 20 (1990), reprinted in 1990 U.S.C.C.A.N. $6803,6823$.

12 See 28 U.S.C. $\$ 473($ a)(6) (Supp. II 1990).

${ }^{13}$ See Use of Alternative Dispute Resolution Procedures Increase, CT. ADMIN. BULL., Feb. 1992, at 2, 2, 18-20.

${ }^{14}$ Federal Courts Study Act, $\$ 102(\mathrm{~b})(2)(\mathrm{A})$, Pub. L. No. 100-702, 1988 U.S.C.C.A.N. (102 Stat.) 4644, 4644 (codified at 28 U.S.C. $\$ 331$ (1988)).

${ }^{15}$ Federal Courts STUdy COMM., Report OF THE Federal COURTS STUdY COMMITTEE 83 (1990). In addition, the recently introduced Access to Justice Act of 1992, S. 2180, 102d Cong., 2d Sess. (1992), includes several ADR provisions and reflects the view that $A D R$ processes should become an integral part of the federal courts. See, e.g., id. $\S 7$. The Act also evidences strong support for using fee and costshifting provisions to induce settlement and discourage unnecessary discovery motions. See, e.g., id. § 3.

${ }^{16}$ See, e.g., MEIERHOEFER, CAA IN TEN DIST. CTS., supra note 4, at 12 (surveying the Federal Judicial Center's empirical studies of the CAA pilot programs and recommending that "Congress enact an arbitration provision . . . authorizing arbitration in all federal district courts, to be mandatory or voluntary in the discretion of the court"); see also Albert W. Alschuler, Mediation with a Mugger: The Shortage of Adjudicative Services and the Need for a Two-Tier Trial System in Civil Cases, 99 HARV. L. REV. $1808,1839-40$ (1986) (endorsing CAA as an access-increasing reform and a sensible response to the shortage of adjudicative services); Barkai \& Kassebaum, supra note 9, at S45 (concluding that "Hawaii's [state] Court-Annexed Arbitration Program increases the pace of litigation and reduces litigation costs while maintaining adequate levels of satisfaction of the participants"); Wayne D. Brazil, A Close Look at Three CourtSponsored ADR Programs: Why They Exist, How They Operate, What They Deliver, and 
parties' litigation decisions have yet to be systematically examined. Furthermore, in their rush to adopt court-connected ADR programs, whose benefits were allegedly proven by the widespread use of private $A D R$, lawmakers have ignored a fundamental difference between the programs they laud and the legislation they have passed-namely that private ADR proceedings are conducted with the parties' consent, while participation in many public ADR processes is required by law.

This Article explores the ways that various features and proposed features of federal CAA programs could be expected to influence litigant behavior. It considers whether, given the availability of private ADR fora at relatively low cost, there are any compelling justifications-from the perspective of either the parties

Whether They Threaten Important Values, 1990 U. CHI. LEGAL F. 303, 397 (arguing that none of the federal CAA programs studied "is seriously vulnerable to criticisms that have been articulated of court-sponsored ADR programs in general, and that each of these programs offers significant benefits to litigants without causing serious harm to competing interests"); Raymond J. Broderick, Yes to Mandatory Court-Annexed ADR, LITIG., Summer 1992, at 3, 60 (arguing that given the caseload in the federal courts, court-annexed ADR is a necessary step in "adapt[ing] our federal judicial system to the ever-changing conditions of national life"); Broderick, supra note 9, at 217 (arguing that "now is the time to consider making court-annexed compulsory arbitration an integral part of our federal judicial system"); Richard A. Enslen, $A D R$ : Another Acronym, or a Viable Alternative to the High Cost of Litigation and Crowded Court Dockets? The Debate Commences, 18 N.M. L. REV. 1, 30-33 (1988) (arguing that while current empirical data do not demonstrate their beneficial effects, the policy arguments in favor of court-annexed ADR programs are so strong that such programs should nevertheless be continued until further studies are concluded); Leo Kanowitz, Alternative Dispute Resolution and the Public Interest: The Arbitration Experience, 38 HASTINGS L.J. 239, 302-03 (1987) (acknowledging some of the arguments against CAA programs, but concluding that on balance, if properly administered, they are likely to be beneficial); Paul Nejelski \& Andrew S. Zeldin, Court-Annexed Arbitration in the Federal Courts: The Philadelphia Story, 42 MD. L. REV. 787 (1983) (arguing for expansion of federal CAA programs); Jessica Pearson, An Evaluation of Alternatives to Court Adjudication, 7 JUST. SYS. J. 420, 420 (1982) (reviewing the empirical literature and concluding that "[c]ompared with their voluntary counterparts, mandatory mediation and arbitration programs come closer to succeeding (and in some cases do succeed) in reducing court congestion and achieving public cost savings too"); Robert F. Peckham, A Judicial Response to the Cost of Litigation: Case Management, Two-Stage Discovery Planning and Alternative Dispute Resolution, 37 RUTGERS L. REV. 253, 267-77 (1985) (arguing in favor of CAA as part of an integrated case management program in the federal courts). But see Kim Dayton, The Myth of Alternative Dispute Resolution in the Federal Courts, 76 IOWA L. REV. 889, 915 (1991) (arguing that the perception that $A D R$ is an effective method of caseload management "lacks solid empirical justification"); G. Thomas Eisele, From the Bench: No to Mandatory Court-Annexed ADR, LITIG., Fall 1991, at 3, 3 (arguing that mandatory non-binding arbitration programs undermine "the symbolic status of our single-judge-generalist Article III federal trial court"). 
or the state-for the federal government to become a provider of mandatory non-binding CAA services.

Part I describes the basic features of federal CAA pilot programs and highlights the most important differences in the local rules governing the programs. Part II focuses on justifications for government provision of GAA services. After briefly describing the market for private ADR, it explores the barriers to parties' contracting for private ADR when its use can produce private benefits, and considers whether mandating participation in non-binding CAA programs will result in parties' capturing these private benefits when such barriers exist. The section then focuses on whether the programs will produce private or social benefits by reducing the number of nuisance ${ }^{17}$ or negative expected value suits ${ }^{18}$ filed, reducing the private or social cost of litigation, decreasing delay, or increasing access to justice.

Part III is the core of the Article. It uses numerical simulations of a model of the litigation process in a CAA jurisdiction with a post-arbitration fee and cost-shifting rule to explore the programs' effect on parties' litigation decisions. ${ }^{19}$ The simulations demonstrate that when both parties are overly optimistic, the most common cause of failure to settle, CAA programs may actually reduce the likelihood of pre-trial settlement. The simulations are also used to explore the programs' effect on the settlement range at various stages in the litigation process and to highlight the programs' largely unanticipated distributional effects. The results suggest that parties are most likely to accept the arbitration award when it most accurately reflects the cost of invoking the judicial process and the inequality of bargaining power between them. Finally, the section discusses the programs' effects on total litigation costs and the amount of discovery conducted, and concludes that CAA programs will tend to systematically disadvantage poorer and more risk-averse litigants, precisely the litigants the programs were designed to help.

Part IV argues that the limits of the ability of court-connected ADR programs to create private value and achieve other social goals can only be understood by exploring the differences between private and public ADR. The section begins by considering the

17 See infra text accompanying note 117 (defining a nuisance suit).

${ }^{18}$ See infra text accompanying note 134 (defining a negative expected value suit).

19 The model used to generate the simulations is presented in the Technical Appendix, infra. 
features of private ADR tribunals that parties find desirable but that cannot be fully replicated in public programs. It then distinguishes between ex ante and ex post ADR agreements and discusses a variety of ways, apart from reducing cost and delay, that private ADR provisions create value. The section concludes that while government-provided ADR may not be a solution to many of the problems facing the federal courts, it might be desirable to amend the Federal Rules of Civil Procedure to explicitly permit parties to contract to use ADR in conjunction with, or as a substitute for, certain pre-trial procedures.

This Article concludes that further experimentation with CAA is undesirable, since contrary to the hopes of the programs' supporters, CAA programs will not succeed in promoting for "all citizens-rich or poor, individual or corporation, plaintiff or defendant-the just, speedy, and inexpensive resolution of civil disputes in our Nation's Federal courts." ${ }^{20}$ Justice for "the middle class of this country [for whom] the courthouse door is rapidly being slammed shut" 21 will not be achieved and many litigants will be even worse off than they would have been in the absence of the program.

\section{The BASIC FeATURES OF COURT-ANNEXED ARBITRATION PROGRAMS}

The Judicial Improvements and Access to Justice Act $^{22}$ sets out the basic structure of federal CAA programs, but gives each district the authority to adopt local rules specifying important program features. ${ }^{23}$

Suits for predominantly money damages that fall below a particular amount in controversy, which, depending on the district, ranges from $\$ 50,000$ to $\$ 150,000^{24}$ and do not involve federal

${ }^{20}$ S. REP. NO. 416, supra note 11, at 1, reprinted in 1990 U.S.C.C.A.N. at 6803.

21 Id. at 6809.

22 Pub. L. No. 100-702, 1988 U.S.C.C.A.N. (102 Stat.) 4642 (codified as amended in scattered sections of 28 U.S.C.).

${ }^{23}$ See id. $\$ 651,1988$ U.S.C.C.A.N. (102 Stat.) at 4659 (codified at 28 U.S.C. $\$ 651$ (1988)).

24 Although 28 U.S.C. $\$ 652(a)(1)(B)$ sets the jurisdictional limit at $\$ 100,000$, it permits districts "whose local rule [already] . . . provides for a limitation on money damages . . of not more than $\$ 150,000$, [to] continue to apply the higher limitation." 28 U.S.C. $\$ 652$ note (1988) (Exception to Limitation on Money Damages). Currently, the $\$ 150,000$ limit applies in the Northern District of California, the Middle District of Florida, the Middle District of North Carolina, and the Western District of Texas. See N.D. CAL. LOC. CT. R. 500(2)(a)(i)(A); M.D. FLA. LOC. CT. R. 
constitutional claims or conspiracies to interfere with civil rights, must be submitted to non-binding arbitration before a trial can be requested. $^{25}$ In some districts, the parties or the trial judge may make a motion to exempt the case from arbitration where "the objectives of arbitration would not be realized ( 1 ) because the case involves complex or novel legal issues, (2) because legal issues predominate over factual issues, or (3) for other good cause. ${ }^{26}$ In most districts the maximum amount in controversy is a jurisdictional limit, not a cap on the damages an arbitrator can award. ${ }^{27}$

8.02(a)(1)(B); M.D.N.C. LOC. CT. R. 602(a)(1); W.D. TEX. LOC. CT. R. CV-87(c)(1)(a). Although the jurisdictional limits are low, "as CAA has spread so has pressure to raise the monetary ceiling; some federal courts are now considering limits of $\$ 200,000$ or more." A Taxonomy of Judicial ADR, 9 ALTERNATIVES 97, 109 (1991). In addition, many judges in the pilot districts support raising the jurisdictional limit and/or broadening the types of cases included in the program. See, e.g., BARBARA MEIERHOEFER, FEDERAL JUDICIAL CTR., COURT-ANNEXED ARBITRATION IN THE EASTERN DISTRICT OF NEW YORK 16 (1989) [hereinafter MEIERHOEFER, CAA IN THE E.D.N.Y.] (indicating that a majority of judges there are generally opposed to increasing the district's $\$ 50,000$ limit, but support including a broader range of cases in the program); BARBARA MEIERHOEFER \& CARROLL SERON, FEDERAL JUDICIAL CTR., COURTANNEXED ARBITRATION IN THE MIDDLE DISTRICT OF FLORIDA 17 (1988) [hereinafter MEIERHOEFER \& SERON, CAA IN THE M.D. FLA.] (noting that four out of six judges support raising the jurisdictional limit, but only three support including a broader range of cases); BARbara MEIERHOEFER \& CARROLl SERON, FEDERAL JUDICIAL CTR., COURT-ANNEXED ARBITRATION IN THE NORTHERN DISTRICT OF CALIFORNIA 17 (1988) [hereinafter MEIERHOEFER \& SERON, CAA IN THE N.D. CAL.] ("[F]ive of the seven judges said they would consider amending their local rule both to add more types of civil cases to the program and to increase the dollar ceiling."); BARBARA MEIERHOEFER, FEDERAL JUdicial. CTR., COURT-ANNEXEd ARBITRATION IN THE WESTERN DISTRICT OF OKLAHOMA 19 (1988) [hereinafter MEIERHOEFER, CAA IN THE W.D. OKLA.] (reporting that judges there support increasing the jurisdictional limit but generally oppose including a broader range of cases).

${ }^{25}$ See 28 U.S.C. $\$ 652$ (1988).

${ }^{26}$ Id. $\$ 652(\mathrm{c})$; see also W.D. OKLA. Loc. CT. R. 43(E). This rule is typical of most programs. The Middle District of North Carolina also provides for an exemption when "mandatory arbitration will not likely accomplish the purpose of these rules." M.D.N.C. LOC. CT. R. 602(b). The most common ground for requesting exemption, however, is that the amount in controversy exceeds the jurisdictional limit. In the Middle District of North Carolina, for example, of the 83 cases designated for arbitration, exemption motions were filed in 40 cases and granted in 31 . See Barbara MEIERHOEFER, FEDERAL JUdICIAL CTR., COURT-ANNEXEd ARBITRATION IN THE MIDDLE DISTRICT OF NORTH CAROLINA 15 \& n.12 (1989) [hereinafter MEIERHOEFER, CAA IN THE M.D.N.C.]. Of the requests, 39 were based at least partially on the grounds that the jurisdictional limit was exceeded. See id. at 17. The exemption rate for cases initially identified as being eligible for arbitration ranges from $4-30 \%$. See MEIERHOEFER, CAA IN TEN DIST. CTS., supra note 4, at 47 tbl. 8.

${ }^{27}$ See, e.g., D.N.J. LoC. Cr. R. $47(\mathrm{C})(4)$, which provides that the arbitrator can award more than the $\$ 100,000$ jurisdictional limit as well as punitive damages. Similarly, neither the Northern District of California nor the Middle District of 
Hearings are conducted by either a single arbitrator or a panel of three arbitrators chosen from a volunteer pool of lawyers. ${ }^{28}$ Hearings take place 80 to 180 days after the filing of the answer and decisions are rendered shortly thereafter. ${ }^{29}$ In some districts, hearings are open to the public, in others, they are closed. ${ }^{30}$ The

Florida impose a limit on the amount the arbitrator can award. See M.D. FLA. Loc. CT. R. 8.05(a); MEIERHOEFER \& SERON, CAA IN THE N.D. CAL., supra note 24, at 55. In the Eastern District of New York, however, arbitrators do not have the authority to render an award greater than $\$ 100,000$. See E.D.N.Y. LOC. ARB. R. 6(a); see also W.D. MICH. LOC. CT. R. 43(i)(2) (allowing awards over $\$ 100,000$ only if both parties consented to arbitration).

${ }^{28}$ In some districts the clerk's office chooses the arbitrators. In others, the parties participate in their selection. See M.D. FLA. LOC. CT. R. 8.03(a) (giving the parties 20 days to select, by agreement, "not more than three certified arbitrators," and noting that if they fail to do so the selection is made by the clerk's office); M.D.N.C. LOC. CT. R. 603(a)(4) (giving the parties 15 days to "select an arbitrator from the list of arbitrators maintained by the clerk ... or [allowing them to] select any other person, whether or not an attorney, on the basis of that person's expertise or experience").

${ }^{29}$ Although not all districts have a rule specifying the length of time an arbitrator has to render a judgment, the emphasis of the programs is on speed. For example, Congress directs the arbitrators to file their awards "promptly after the arbitration hearing is concluded." 28 U.S.C. $\$ 654$ (a) (1988). The Western District of Michigan provides that " $[t]$ he arbitrator shall endeavor to announce the award to the parties immediately upon conclusion of the hearing, but in any event shall file the award . . . not more than ten . . . days following the close of the hearing." W.D. MICH. LOC. Cr. R. 43(i)(1); see also W.D. OKLA. Loc. Cr. R. 43(O)(1) (same).

${ }^{30}$ All of the local district court rules dealing with the CAA pilot programs are silent on the question of whether or not non-parties have a right to attend arbitration hearings. However, most districts have an informal policy regarding access to arbitration hearings. In the Eastern District of Pennsylvania, the Middle District of North Carolina, and the Eastern District of New York, where the CAA program is viewed as an alternative to a trial rather than as a settlement device, see BARBARA MEIERHOEFER, FEDERAL JUDICLAL CTR., COURT-ANNEXED ARBITRATION IN THE EASTERN District OF PENNSYlVANIA 1 (1988) [hereinafter MEIERHOEFER, CAA IN THE E.D. PA.]; MEIERHOEFER, CAA IN THE E.D.N.Y., supra note 24, at 1-2; MEIERHOEFER, CAA IN THE M.D.N.C., supra note 26 , at 1 , the arbitration hearings are conducted in the courthouse and are open to the public. Although a party may make a motion to close the hearing, in deciding whether or not to grant the motion, the judge will apply the same standard that would be used to determine whether or not to grant a motion to close a trial to the public. Telephone Interview with Mr. Heinerich, Clerk, Eastern District of New York (Apr. 24, 1993); Telephone Interview with Joseph Benedetto, Chief Deputy Clerk, Eastern District of Pennsylvania (Apr. 23, 1993); Telephone Interview with Mr. Creekmore, Arbitration Clerk, Middle District of North Carolina (Apr. 23, 1993). In contrast, in the District of New Jersey, the Western District of Oklahoma, the Middle District of Florida, and the Northern District of California, where the arbitration hearing is viewed as either a settlement device or a case management technique, see BARBARA MEIERHOEFER, FEDERAL JUDICIAL CTR., COURTANNEXED ARBITRATION IN THE DISTRICT OF NEW JERSEY 1-2 (1989) thereinafter MEIERHOEFER, CAA IN THE D.N.J.]; MEIERHOEFER \& SERON, CAA IN THE M.D. FLA., supra note 24, at 1-2; MEIERHOEFER \& SERON, CAA IN THE N.D. CAL., supra note 24, at 1; MEIERHOEFER, CAA IN THE W.D. OKLA., supra note 24, at 1-2, arbitration 
amount of pre-arbitration discovery permitted ${ }^{31}$ and the types of pre-trial motions decided prior to the hearing are governed by local rule, subject to certain constraints imposed by Congress. ${ }^{32}$

hearings are frequently held in the arbitrator's office and are generally closed to the public. This practice, however, has never been challenged. Telephone Interview with Carol Coleman, Arbitration Clerk, District of New Jersey (Apr. 23, 1993); Telephone Interview with Jane Cummings, Chief Deputy Clerk, Middle District of Florida (Apr. 23, 1993); Telephone Interview with Davis Loupe, ADR Administration, Northern District of California (Apr. 23, 1993); Telephone Interview with Patricia Presley, Deputy Court Clerk, Western District of Oklahoma (Apr. 23, 1993). In the Western District of Missouri, which recently discontinued its CAA program, the hearing was viewed as a substitute for trial, but was closed to the public. Telephone Interview with former Arbitration Clerk, Western District of Missouri (Apr. 23, 1993).

${ }^{31}$ All CAA programs seek to reduce litigant costs by limiting pre-arbitration discovery in some way-most commonly by imposing strict discovery deadlines. See, e.g., E.D. PA. LOC. CT. R. 8(4)(A) (stating that parties have "(90) days . . from the date the answer was filed to complete discovery unless the judge to whom the case has been assigned orders a shorter or longer period"); M.D. FLA. LOC. CT. R. 8.03(a), 8.04(a) (noting that parties have 20 days to choose an arbitrator, and if they fail to agree, the clerk selects one, with the hearing held within 90 days thereafter); M.D.N.C. LOC. CT. R. 603(a)(3), (d) (establishing "a 90 day deadline for the conduct of discovery which must be completed in a diligent and expeditious fashion"); N.D. CAL. LOC. CT. R. 500(5)(a) (providing that the arbitration hearing must be held 20 to 120 days after referral to the program); W.D. MICH. LOC. CT. R. 43(g) (limiting discovery to "one hundred and twenty ... days from and after the last responsive pleading"); W.D. MO. LOC. CT. R. 30(E)(1) (stating that the parties have 120 days to complete discovery and cautioning that the standards for granting an extension of this period are very strict); W.D. OKLA. LOC. CT. R. 43(G)(1), (4) (attempting to limit discovery more directly by providing that only "[c]ritical discovery necessary for purposes of meeting the goals of an arbitration hearing shall be completed prior to the hearing," which is normally held "prior to the discovery cut-off date scheduled for the trial case"); W.D. TEX. LOC. CT. R. CV-87(f)(1) (providing that the "hearing shall begin no later than sixty (60) days after the filing of an answer"); MEIERHOEFER, CAA IN THE D.N.J., supra note 30 , at 10 (reporting that the hearing is usually held six months after the answer is filed).

Two jurisdictions also have rules limiting post-arbitration discovery. M.D.N.C. LOC. CT. R. 603(d) provides that "[e]xcept in exceptional circumstances, no additional discovery will be permitted when a trial de novo has been demanded after an arbitration award." Combined with the district's 90-day deadline for the conduct of discovery, the CAA program appears to be largely a discovery control tool. See M.D.N.C. LOC. CT. R. 603(a)(3); see also W.D. MO. LOC. CT. R. 30(K)(1) (stating that post-arbitration discovery is only permitted on motion accompanied by a very specific statement of what is sought and a proposed scheduling order).

For a discussion of the ways these discovery limitations might increase the cost of discovery and reduce the amount of information exchanged, see infra notes 221-28 and accompanying text.

32 See 28 U.S.C. $\$ 653(\mathrm{~b})$ (1988). The statute provides:

[a]n arbitration hearing under this chapter shall begin within a time period specified by the district court, but in no event later than 180 days after the filing of an answer, except that the arbitration proceeding shall not, in the absence of the consent of the parties, commence until 30 days after the 
At the arbitration hearing, the Federal Rules of Evidence do not apply. ${ }^{33}$ Arbitrators may permit the introduction of any credible non-privileged evidence, including hearsay. ${ }^{34}$ The arbitrators are not required to issue written or oral findings of fact or conclusions of law, ${ }^{35}$ and at least one district prohibits them from doing so. ${ }^{36}$ A few districts encourage live testimony, ${ }^{37}$ while others discourage it, providing by local rule that "the presentation of testimony shall be kept to a minimum, and that cases shall be presented to the arbitrators primarily through the statements and arguments of Counsel. ${ }^{\text {38 }}$ One district bans live testimony altogether and requires that "[a]ll evidence shall be presented through counsel who may incorporate argument on such evidence in his or her presentation. ${ }^{n 9}$ Some programs limit the length of the hearing. ${ }^{40}$

disposition by the district court of any motion to dismiss the complaint, motion for judgment on the pleadings, motion to join necessary parties, or motion for summary judgment, if the motion was filed during a time period specified by the district court. The 180-day and 30-day periods specified in Id. the preceding sentence may be modified by the court for good cause shown.

${ }^{33}$ See, e.g., M.D.N.C. LOC. ARB. R. 606(g) ("The arbitrator shall weigh all evidence presented upon assessment of its relevance and trustworthiness. The Federal Rules of Evidence shall not apply, except for rules concerning privilege or protection."); see also N.D. CAL. LOC. CT. R. 500(5)(c) ("[T] he arbitrator shall be guided by the Federal Rules of Evidence, but shall not thereby be precluded from receiving evidence which he considers to be relevant and trustworthy and is not privileged."); W.D. TEx. LOC. CT. R. CV-87(f)(4)(a) (same).

${ }^{34}$ See supra note 33.

${ }^{35}$ See, e.g., W.D. TEX. LOC. CT. R. CV-87(g)(2) (providing that the award need only "state clearly and concisely the name or names of the prevailing party or parties and the party or parties against which it is rendered, and the precise amount of money or other relief, if any, awarded").

${ }^{36}$ According to a leading CAA proponent, the Honorable Raymond J. Broderick, Senior Judge, U.S. District Court, Eastern District of Pennsylvania:

[a]t the conclusion of the testimony, the panel makes an award-for example, in favor of the plaintiff in the amount of $\$$ _ against one or more defendants or in favor of the defendant(s). The arbitrators are instructed not to file findings of fact, conclusions of law, or an opinion of any kind.

They are not to indicate whether the decision was or was not unanimous. Broderick, supra note 16 , at 4 .

${ }^{37}$ See, e.g., N.D. CAL. LOC. CT. R. 500(5)(c) (noting that "attendance of witnesses may be compelled").

${ }^{38}$ M.D. FLA. LOC. CT. R. 8.04(d); see also W.D. MiCH. LOC. CT. R. 43(h)(5) (providing that although witnesses may testify, "[i]t is contemplated that presentations will be made in summary fashion"); W.D. MO. LOC. CT. R. 30(H)(5) (providing that "[t]he presentation of testimony should be kept to a minimum").

${ }^{39}$ W.D. OKLA. LOC. CT. R. 43(I)(3).

${ }^{40}$ See W.D. MICH. LOC. CT. R. 43(h)(5) (providing that "[e]ach party shall be allowed a maximum of $21 / 2$ hours for the presentation of its case $\left.{ }^{n}\right) ; W . D$. OKLA. LOC. 
Good faith participation in the arbitration hearing is required of both the parties and their counsel. ${ }^{41}$ Most districts require parties to be present at the hearing, ${ }^{42}$ and some districts require the presence of a person with full settlement authority. ${ }^{43} \mathrm{Al}$ though the authority of the court to order a person with settlement authority to be present at an arbitration hearing has yet to be definitively established, an en banc panel of the Seventh Circuit has upheld a district judge's authority to order a person with full settlement authority to be present at a settlement conference. ${ }^{44}$ In some districts, if either the nonattendance of a party or the preparation and presentation of counsel is deemed not to constitute "participation in a meaningful way" in the arbitration process, the court can impose monetary sanctions and/or strike a party's

Cr. R. 43(I)(2) (giving each side one hour to present its case).

${ }^{41}$ See W.D. OKLA. LOC. CT. R. 43(I)(5) (providing that "failure to participate in good faith may constitute default" ); D.N.J. LOC. CT. R. 47(E)(3) (giving the judge the right to impose sanctions for failure to meaningfully participate in the arbitration hearing); E.D. PA. LOC. CT. R. 8(E) ("In the event, however, that a party fails to participate in the trial [before the arbitrators] in a meaningful manner, the court may impose additional sanctions, including but not limited to the striking of any demand for a trial de novo by that party."); W.D. MO. LOC. CT. R. 30(L) ("If a party fails to participate in the arbitration process in a meaningful fashion, the Court may impose appropriate sanctions, including but not limited to an entry of judgment by the Court upon the arbitrators' award.").

42 See, e.g., M.D. FLA. LOC. R. 8.04(d) ("Individual parties or authorized representatives of corporate parties shall attend the arbitration hearing unless excused in advance by the arbitrators for good cause shown."); M.D.N.C. LOC. CT. R. 606(f) (requiring parties to be present at the arbitration hearing unless excused in "exceptional circumstances").

${ }^{43}$ See, e.g., W.D MiCH. Loc. CT. R. 43(h)(4) ("Each individual who is a party shall attend the hearing in person. Each party which is a corporation, governmental body, or other entity, including an unnamed party, shall be represented at the hearing by an officer or other person with complete settlement authority."); W.D. OKLA. LOC. CT. R. 43(I)(I)-(2) ("In addition to lead counsel . . . a person with actual settlement authority must ... be present for the hearing. This may not be counsel (except inhouse [sic] counsel) . . . Other interested parties such as insurers or indemnifiers shall attend and are subject to the provisions of this Rule.").

${ }^{44}$ See G. Heileman Brewing Co. v. Joseph Oat Corp., 848 F.2d 1415 (7th Cir. 1988) (en banc); see also Lockhart v. Patel, 115 F.R.D. 44, 46, 47 (E.D. Ky. 1987) (discussing, in an opinion filed after the case had been settled, the court's authority to strike the defendant's pleadings as a sanction for failing to obey an order that a person with full settlement authority attend a settlement conference and concluding that the authority existed, since the "exigencies of modern dockets demand the adoption of novel and imaginative means [such as] ... compulsory arbitration, summary jury trials, imposing reasonable limits on trial time, or, as here, the relatively innocuous device of requiring a settlement conference [to be] attended by the clients as well as the attorneys"). 
demand for a trial de novo ("trial"). ${ }^{45}$ The court's authority to strike a party's demand for a trial has been upheld by several district courts, ${ }^{46}$ but has not yet been considered by any court of appeals.

After the arbitrator has rendered an award, which may, depending on the local rule, include costs, ${ }^{47}$ each party has thirty days to request a trial. ${ }^{48}$ When a party requests a trial, the case is restored to its original place on the docket and treated as if it had never been arbitrated; neither the record of the hearing, if made, ${ }^{49}$ nor the arbitrators' decision are admissible at trial. ${ }^{50}$ In the pilot districts, trial de novo request rates range from forty-six to seventyfour percent of arbitrated cases. ${ }^{51}$

Some districts have disincentives to requesting a trial. Most districts require the party requesting a trial to post a bond with the court in the amount of the arbitrators' fees and costs which,

45 See supra note 41 and accompanying text.

${ }^{46}$ See, e.g., New England Merchants Nat'l Bank v. Hughes, 556 F. Supp. 712 (E.D. Pa. 1983), where the court struck the defendant's request for a trial after concluding that (1) the defendant received notice of the arbitration hearing, (2) the defendant never requested a continuance, (3) neither the defendant nor counsel nor any witnesses on her behalf appeared at the arbitration hearing, (4) defendant gave no reason for her failure to appear, and, in contrast, (5) the plaintiff appeared at the hearing, presented evidence, and was awarded a recovery. In Block v. T.G.\& Y Stores Co., No. 87-0490-CV-W-9, 1989 U.S. Dist. WL 23202, at *1 (W.D. Mo. Feb. 22, 1989), the court struck the defendant's request for a trial on the grounds that he had failed to meaningfully participate in the arbitration hearing. The court noted that "[w]ithout an enforceable requirement that litigants participate meaningfully in the arbitration process, the goals of the arbitration program are threatened .... Essentially, arbitration would be a default proceeding, a meaningless proceeding preparatory to a district court trial.” Id. at *3-*4. Similarly, in Gilling v. Eastern Airlines, 680 F. Supp. 169 (D.N.J. 1988), the court imposed sanctions on a corporate defendant litigating against an individual plaintiff for failure to participate in a CAA hearing in good faith. It noted that the

purposes [of the program] are thwarted when a party to the arbitration enters into it with the intention from the outset of rejecting its outcome and demanding a trial de novo. Rather than reducing the cost and promoting efficiency in the system, such an attitude increases the costs and reduces the efficiency. Furthermore, such conduct can serve to discourage the poorer litigant and diminish his or her resolve to proceed to final judgment.

Id. at 170 .

${ }^{47}$ See 28 U.S.C. $\$ 655(d)(1)(a)(1988)$.

${ }^{48}$ See id. \$ 655(a).

${ }^{49}$ No public record of the arbitration is made, but most programs permit a party to make a record at his own expense if it is done in an unobtrusive manner and a copy is provided to his opponent free of charge. See, e.g., M.D.N.C. Loc. CT. R. 606(c); N.D. CAL. LOC. CT. R. 500(5)(d); W.D. MICH. LOC. CT. R. 43(a)(6); W.D.

OKLA. LOC. CT. R. 43(5); W.D. TEX. LOC. CT. R. CV-87(f)(5).

${ }^{50}$ See 28 U.S.C. $\$ 655(c)$.

51 See MEIERHOEFER, CAA IN TEN DiST. CTs., supra note 4, at 49 tbl. 9. 
depending on the district and the number of arbitrators, can range from $\$ 125$ to $\$ 450$ for the typical case. ${ }^{52}$ Although complex cases often cost substantially more to arbitrate, most districts put a cap on the amount of the bond a party can be required to post in order to obtain a trial. ${ }^{53}$ If the party requesting the trial improves his position at trial, this bond is returned to him; if he fails to do so, it is retained by the court. ${ }^{54}$

In the past, some districts had a rule requiring the party requesting a trial to pay his opponent's post-arbitration attorneys' fees and/or costs if he failed to improve his position at trial. ${ }^{55}$ The authority of courts to enact such local rules absent congressional authorization was a question of some dispute. In 1988, Congress decided that pending further study by the Federal Courts Study Committee, such provisions should not be part of the pilot programs. ${ }^{56}$ However, in its 1990 report, the Committee recommended that Congress authorize the pilot districts to experiment with fee and cost-shifting provisions, ${ }^{57}$ common features of many state CAA programs. ${ }^{58}$

${ }^{52}$ See id. at 38 tbl. 3G. Some districts have recently increased arbitrator fees. Other districts "offer non-monetary incentives to arbitrators by exempti[ng] them from certain Criminal Justice Act appointments." Id. at 37.

${ }^{53}$ For example, in the Middle District of North Carolina, $\$ 800$ is the maximum bond that can be required. See M.D.N.C. LOC. CT. R. 604(d) (describing the calculation of the maximum permissible arbitration fees and costs); see also E.D. PA. LOC. CT. R. 8(7)(E) (setting the maximum bond at $\$ 75$ per arbitrator).

${ }^{54}$ See MEIERHOEFER, CAA IN TEN DIST. CTS., supra note 4, at 40 tbl. 3I (summarizing the disincentives to requesting a trial de novo). In some districts, the court retains the authority to return the bond if the trial was requested "for good cause." 28 U.S.C. $\$ 655(2)$ (B) (1988); see also M.D. FLA. LOC. CT. R. 806(d).

${ }^{55}$ The Northern District of California had a post-arbitration cost-shifting rule. See MEIERHOEFER, CAA IN TEN DIST. CTS., supra note 4, at 134. The Western District of Michigan had a rule providing that attorney fees could be shifted if the party requesting a trial did not obtain a trial judgment $10 \%$ more favorable than the arbitration award. See id. The Western District of Oklahoma had a similar rule but both costs and fees were shifted. See id. at 136.

${ }^{56}$ Federal Courts Study Act, $\S 102(\mathrm{~b})(2)(A)$, Pub. L. No. 100-702, 1988 U.S.C.C.A.N. (102 Stat.) 4644, 4644 (codified at 28 U.S.C. $\$ 331$ (1988)).

${ }^{57}$ See Federal CourTs STUdy COMM., supra note 15, at 81.

58 For example, in the Arizona state court-annexed arbitration program, when a party requests a trial:

If the judgment on the trial de novo is not more favorable ... [than] the arbitration award, the court shall order the deposit [of the arbitrator's fees posted at the time the trial was requested] to be used to pay, or that the appellant pay if the deposit is insufficient, the following costs and fees, unless the [c]ourt finds on motion that the imposition of costs and fees would create such a substantial economic hardship as not to be in the interests of justice: (i) To the county, the compensation actually paid to the 
If a trial is not requested within thirty days of the arbitration decision, the decision is entered as the judgment of the court and has the same force and effect as a trial judgment. ${ }^{59}$ It cannot, however, be appealed. ${ }^{60}$

The pilot programs also permit litigants in any civil action or in any adversarial bankruptcy proceeding to voluntarily submit their case to arbitration. ${ }^{61}$ In some districts, when cases are submitted to the program with the parties' consent and a trial is requested, the court

may assess costs ... and reasonable attorney fees against the party demanding trial de novo if ... such party fails to obtain a judgment, exclusive of interest and costs ... which is substantially more favorable to such party than the arbitration award, and ... the court determines that the party's conduct in seeking a trial de novo was in bad faith. ${ }^{62}$

Although all districts permit parties to voluntarily submit disputes to arbitration either for free or at a minimal cost, ${ }^{63}$

arbitrator; [and] (ii) To the appellee, those costs taxable in any civil action together with reasonable attorneys' fees as determined by the trial judge for services necessitated by the appeal.

ARIz. UNIF. R. P. 7(f); see also Colo. REv. STAT. ANN. 13-22-405 (West 1990) (requiring a party who rejects an arbitration award and fails to improve his position at trial by $10 \%$ to "pay all of the costs, including attorney fees and arbitrator fees, of the arbitration proceeding not to exceed one thousand five hundred dollars ${ }^{n}$ ); FLA. STAT. ch. 44.303(5) (1989) ("The party having filed for a trial de novo shall be assessed the arbitration costs, court costs, and other reasonable costs of [his opponent] . . . if the judgment upon the trial de novo is not more favorable than the arbitration decision."); CAL. CIV. PRO. CODE $\$ 1141.21$ (West 1993) (describing the consequences for a party failing to improve on the arbitration award after requesting trial de novo); HAw. ARB. R. 26 (giving the court the discretion to impose "[r]easonable costs and fees (other than attorney's fees) actually incurred by the party but not otherwise taxable under the law ... [ [as well as c]osts of jurors . . . [and a]ttorneys' fees not to exceed $\$ 5,000$," when the party requesting trial fails to improve his position at trial by $15 \%$ of the arbitration award); MiCH. CT. R. 2.403(O)(1)-(4) (describing fee and cost-shifting consequences of demanding a trial after participation in Michigan's mandatory mediation program).

${ }^{59}$ See 28 U.S.C. $\$ 654(a)$ (1988).

${ }^{60}$ See id.

${ }^{61}$ See id. $\$ 652(\mathrm{~b})$.

62 Id. $\$ 655(\mathrm{e})$. Note that the post-arbitration fee and cost-shifting rule considered in parts II and III of this Article does not contain a "bad faith" requirement.

63 In most districts, parties who accept the arbitration award do not have to pay an arbitration fee to the court. In the District of New Jersey, however, parties must agree to pay the arbitrators $\$ 150$, and in the District of Texas they must agree to pay the arbitrators a reasonable fee. See MEIERHOEFER, CAA IN THE D.N.J., supra note 24, at 24; BARBARA MEIERHOEFER, FEDERAL JUDICIAL CTR., COURT-ANNEXED ARBITRATION IN THE WESTERN DISTRICT OF TEXAS 16 (1989) [hereinafter MEIERHOEFER, CAA IN THE 
litigants rarely choose this option. ${ }^{64}$ In Michigan, where CAA has been available since 1978 and cases submitted to the program by consent are subject to a post-arbitration fee and cost-shifting rule, ${ }^{65}$ only two cases have been submitted to the program by consent. ${ }^{66}$ In the Northern District of California where voluntary CAA has also been available since 1978 , but cases submitted to the program by consent are not subject to a post-arbitration fee and cost-shifting rule, voluntary participation in the CAA program is also rare. ${ }^{67}$

\section{The Market for Dispute Resolution AND JUStifications FOR GOVERNMENT INTERVENTION}

Although parties do not voluntarily opt to participate in CAA programs and trial de novo request rates are high, such programs might nevertheless be desirable if they could produce either private or social benefits that would not otherwise be created. This section briefly describes the market for private ADR and explores the barriers to the parties' contracting for private ADR in situations where it can produce private benefits. It also considers the ability of the programs to create private benefits in situations where such barriers exist as well as their ability to create social benefits such as reducing the number of nuisance or negative expected value suits filed, reducing the private or social costs of litigation, reducing delay, and increasing access to justice.

W.D. TEX.].

${ }^{64}$ For example, during the first two years of CAA in the Middle District of Florida, only two cases were submitted to the program by consent, and voluntary participation "is expected to remain uncommon." MEIERHOEFER \& SERON, CAA IN THE M.D. FLA., supra note 24, at 55. In the Middle District of North Carolina, arbitration by stipulation (consent) occurs infrequently, see MEIERHOEFER, CAA IN THE M.D.N.C., supra note 26 , at 19 , and during the first year that a CAA program operated in the Eastern District of New York, only two cases were voluntarily submitted to the program. See MEIERHOEFER, CAA IN THE E.D.N.Y., supra note 24; see also MEIERHOEFER, CAA IN TEN DIST. CTS., supra note 4, at 11 (reporting that "voluntary alternative programs in other jurisdiction have been notably unsuccessful in attracting cases").

${ }^{65}$ See W.D. MICH. LoC. CT. R. 43(j)(4). 1991).

${ }^{66}$ Telephone Interview with Arbitration Clerk, Western District of Michigan (Oct.

${ }^{67}$ Telephone Interview with Arbitration Clerk, Northern District of California (May 1992); see also MEIERHOEFER \& SERON, CAA IN THE N.D. CAL., supra note 24, at 53 ("On rare occasions, lawyers request arbitration after an initial status conference at which the judge suggests arbitration as a useful way of proceeding."). 


\section{A. The Market for Private ADR Services}

The market for private dispute resolution fora is flourishing. ${ }^{68}$ Between 1983 and 1988, the number of private ADR providers has increased tenfold. ${ }^{69}$ Some private ADR providers offer a variety of relatively informal dispute resolution services, ${ }^{70}$ while others try to replicate the court system. ${ }^{71}$ In addition to for-profit ${ }^{72}$ and not-for-profit fee-for-service ADR providers, over 150 grass-roots ADR organizations currently provide dispute resolution services either free or at a minimal cost. ${ }^{73}$

As the number of ADR providers has increased, so too has attorney awareness of alternatives to litigation. Over the past decade there have been numerous national conferences on $\mathrm{ADR},{ }^{74}$

${ }^{68}$ Lawyers are beginning to view the proliferation of private ADR providers as creating a "market" for dispute resolution. See, e.g., Ellen J. Pollock, Mediation Firms Alter the Legal Landscape, WALL ST. J., Mar. 22, 1993, at B1 (quoting Howard V. Golub, general counsel of Pacific Gas \& Electric Co., as saying, "I think that we are witnessing the emergence of a [free] market in dispute resolution which is challenging the traditional state-owned monopoly in dispute resolution-which, of course, is the courts"); Joseph D. Steinfield, Mediation: The Way of the Future, MASS. LAW. WKLY., Mar. 8, 1993, at 1 (explaining that " $[w]$ hereas lawyers used to choose between federal and state court, or between various state courts and counties, now they and their clients can choose from such additional forums as Endispute, ADR Inc., Judicate, ADR Solutions, Judges Arbitration and Conciliation Services, Inc., Commonwealth Mediation and Conciliation, and many others").

${ }^{69}$ See Harry N. Mazadoorian, For-Profits Take Firm Hold on Field, BAR LEADER, Sept.-Oct. 1988, at 22, 22. In addition, from 1988 to 1992, Judicial Arbitration and Mediation Services experienced revenue growth of $826 \%$ and Endispute experienced 130\% revenue growth. See Richard Phalon, Privatizing Justice, FORBES, Dec. 7, 1992, at $126,126$.

${ }^{70}$ For example, the American Arbitration Association and the Center for Public Resources offer a variety of arbitration, mediation, and conciliation programs.

${ }^{71}$ For example, Judicate, a publicly held company with revenues of $\$ 4$ million in the first three quarters of 1992, operates private courtrooms all over the country. See Pollock, supra note 68, at B1. Judicate advertises itself as the National Private Court

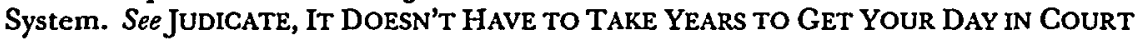
(1992). A bailiff is present and retired judges preside over trials. According to the Judicate Rules of Procedure, unless varied by agreement of the parties, the Federal Rules of Evidence apply, see JUDICATE R.P. 14(a), discovery is governed by the procedural rules "which would be applicable if the case was held in the appropriate court of public jurisdiction," $i d$. at $R$. 11, and "all rulings on substantive legal issues shall be based upon the same principles of law which would be applicable if the case were heard in the appropriate court of public jurisdiction." Id. at R. 2(d).

72 See Pollock, supra note 68, at B1 (reporting that estimated revenues for major arbitration and mediation firms are: American Arbitration Association- $\$ 37$ million; Judicial Arbitration and Mediation Services, Inc.- $\$ 25$ million; Endispute- $\$ 4.8$ million; and U.S. Arbitration- $\$ 5.5$ million).

${ }^{73}$ See Enslen, supra note 16, at 26.

${ }^{74}$ For references to some of the more prominent ADR conferences, see Lisa G. 
law schools have continued to add ADR courses to their curricula, ${ }^{75}$ and a prestigious New York law firm recently published a book on the use of ADR in legal practice. ${ }^{76}$ A number of state bar associations have either amended or are considering amending their ethical codes to impose a mandatory ethical duty to discuss ADR with clients, ${ }^{77}$ and at least one federal district court requires both lawyers and clients to sign a stipulation prior to the first scheduling conference affirming that "each party and that party's counsel have conferred ... to consider the resolution of the litigation through the use of alternative dispute resolution programs."78 Recently, 1460 law firms, ${ }^{79}$ including the ten largest in the country, ${ }^{80}$ signed the Law Firm Policy Statement on Alternatives to Litigation,

Lehrman, The Teaching of Alternative Dispute Resolution, 37 J. LEGAL EDUC. 37, 37 n.1, 39 (1987); Leonard Riskin, Mediation in the Law Schools, 34 J. LEGAL EDUc. 259, 259 n.1 (1984); Albert M. Sacks, Legal Education and the Changing Role of Lawyers in Dispute Resolution, 34 J. LEGAL EDUC. 237, 244 (1984).

75 See Riskin, supra note 74, at 260 n.3 (noting that "summaries of forty-seven law schools' efforts in alternative dispute resolution ... [can be found in the] ABA Special Committee on Alternative Methods of Dispute Resolution, Law School Directory of Dispute Resolution Services (Washington, D.C. 1983)); see also Frank E.A. Sander, Alternative Dispute Resolution in the Law School Curriculum: Opportunities and Obstacles, 34 J. LEGAL EDUC. 229, 235 n.33 (1984). In addition, there have been numerous articles published on methods of teaching ADR. See, e.g., Leonard L. Riskin \& James E. Westbrook, Integrating Dispute Resolution Into Standard First-Year Courses: The Missouri Plan, 39 J. LEGAL EDUC. 509, 512-14 (describing ADR simulations and exercises used in first-year courses).

${ }^{76}$ See Donovan LeIsURe Newton \& IRVINE, ADR PRACTICE BOOK (John H. Wilkinson ed., 1990).

77 Colorado recently added a provision to its Code of Professional Responsibility which provides that "[i]n a matter involving or expected to involve litigation, a lawyer should advise the client of alternative forms of dispute resolution which might reasonably be pursued to attempt to resolve the legal dispute or reach the legal objective sought." Richard E. Lemer, Legislative Activity in the States, N.Y.L.J., Aug. 6,1992 , at 3. Fifteen other states are considering adopting similar provisions. See Colorado Adopts Ethics Rules, 10 AlteRNATIVEs 70, 80 (1992).

${ }^{78}$ Steinfield, supra note 68, at 1 (citing D. MASS. LOC. CT. R. 16.1(D)(3)). In addition, some states routinely provide parties with a list of local ADR practitioners when a complaint is filed. For example, in Missouri, "litigants are referred by the court ADR notice to the local bar association, which maintains a listing of available neutrals." A Taxonomy of Judicial ADR, 9 ALTERNATIVES 98, 98 (1991). In addition, "[i]n the Northern District of California, the court clerk's office keeps a list of organizations, firms, and individuals who have told the court that they offer ADR Services." Id.

${ }^{79}$ See CPR Legal Program, Center for Pub. Resources, CPR LAW Firm Policy STATEMENT: Alternatives to Litigation (1991) [hereinafter Alternatives to LITICATION].

${ }^{80}$ Among the firms signing the policy statement are Baker \& McKenzie; Skadden, Arps, Slate, Meagher \& Flom; Gibson, Dunn \& Crutcher; and Arnold \& Porter. See Rorie Sherman, Big Law Firms Join ADR Sign-athon, NAT'L L.J., Oct. 28, 1991, at 2. 
which reads, in part, "for many disputes there may be more effective methods of resolution than traditional litigation ... appropriate lawyers in our firm will be knowledgeable about ADR . . . and where appropriate, the responsible attorney will discuss with the client the availability of $A D R$ procedures so the client can make an informed choice concerning resolution of the dispute. ${ }^{n 1}$

On the client side, the information campaign launched by the non-profit Center for Public Resources has led to widespread corporate awareness of ADR. This campaign persuaded 600 large corporations and 1800 subsidiaries, including more than half of the Fortune 500 companies, ${ }^{82}$ to sign the Corporate Policy Statement on Alternatives to Litigation, which provides, in part, that "[i]n the event of a business dispute between our corporation and another corporation which has made or will then make a similar statement, we are prepared to explore with that other party, resolution of the dispute through negotiation or ADR techniques, before resorting to full scale litigation."83 Recently, General Mills, Inc., a Fortune 500 company, announced that it will refuse to transact with anyone who is unwilling to include an ADR clause in the agreement. ${ }^{84} \mathrm{ADR}$ has become an increasingly common subject in the popular press, ${ }^{85}$ and there is tremendous public awareness of ADR.

\section{B. Barriers to the Voluntary Use of Private $A D R$}

The large variety of dispute resolution providers and the relatively good information that most attorneys and many clients, particularly large corporations, have about ADR, suggest that there is neither a "market failure" ${ }^{86}$ nor an "information failure" ${ }^{87}$ in

81 ALternatives to LITIGATION, supra note 79.

${ }^{82}$ See Victoria A. Cundiff, Companies Are Seeking Litigation Alternatives, NAT'L L.J., May 17, 1993, at $\mathrm{S} 25$.

${ }^{83}$ CPR Legal Program, Center for Pub. Resources, Corporate Policy STATEMENT: ALTERNATIVES TO LITIGATION (1991).

${ }^{84}$ See Deborah Jacobs, Controlling Litigation Costs with a Neutral Third Party, N.Y. TIMES, Sept. 23, 1990, at 12.

${ }^{85}$ Using the search term "alternative dispute resolution," a search of the Nexis database MAJPAP (major newspapers) found that from 1980 to 1985 there were 14 ADR-related stories, from 1985 to 1990 there were 88 stories, and from 1991 to April 23, 1993, there were 143 stories. A search of the MAGS (magazines) database found 11 stories from 1980 to 1985,90 stories from 1985 to 1990 , and 102 stories from 1991 to April 23, 1993. Similarly, a search of the LGLNEW (legal news) database found 74 stories from 1980 to 1985,373 stories from 1985 to 1990 , and 779 stories from 1991 to April 23, 1993.

${ }^{86}$ If the market for private ADR is said to have failed in that the cost of private 
the market for ADR fora. Consequently, in order to justify a regime of publicly provided ADR on the grounds that it will produce private benefits, it is necessary to consider whether there are any barriers to the parties' contracting for private ADR when ADR processes can produce joint gains, ${ }^{88}$ and whether in those instances where ADR can produce such gains but will nevertheless not be used, mandatory non-binding CAA programs will enable the parties to realize such gains. This section considers several possible barriers to the parties' realizing the joint gains from private ADR, such as legal restrictions, fear of signaling weakness, transactions costs, asymmetric ability to bear the costs of delay, lawyer-client conflicts of interest, and unequal bargaining power in the tort context. It argues that to the extent that such barriers exist, most can be eliminated through minor changes in pre-trial practice, and those that cannot be eliminated through minor procedural changes, such as the asymmetric ability to bear the costs of delay, lawyerclient conflict of interest, and unequal bargaining power in the tort

ADR is viewed as prohibitively high, this might justify a government subsidy for submitting disputes to voluntary, binding, private ADR programs, but it does not provide a justification for government provision of mandatory non-binding CAA programs.

87 If lack of information accounts for parties' failure to opt for private ADR, this problem can be solved by imposing an ethical obligation on lawyers to discuss ADR with clients, see supra note 77 , by requiring parties and lawyers to sign a stipulation that they have considered resolving the dispute through private ADR, see supra note 78 and accompanying text, or by encouraging or requiring judges to initiate discussion of ADR during pre-trial conferences. During a pre-trial conference, a judge is permitted not only to encourage settlement, but also to suggest that the parties explore, "the use of extrajudicial procedures to resolve the dispute." FED. $R$. Civ. P. 16(c)(7). According to the Federal Rules Advisory Committee, "this includes urging the litigants to employ adjudicatory techniques outside the courthouse." FED. R. CIV. P. 16(c)(7) advisory committee note 2.

${ }^{88}$ If ADR processes achieve results that parties consider as valid and fair as a litigated outcome but at a lower cost and with less delay than the court system, in the absence of strategic behavior, parties will opt for private ADR whenever the cost of doing so is less than the joint cost of going to trial. Similarly, if parties believe that a non-binding CAA hearing will be as or more effective than civil discovery in eliciting the type of information that is likely to lead to settlement, parties will agree to private non-binding arbitration whenever the cost of doing so is less than the joint cost of discovery.

Even if the benefits of private ADR are asymmetric, ADR might nevertheless be used if the party who benefits more from its use makes a side payment to his opponent to equalize the gain from using the alternative process. In a contract setting, an $A D R$ provision might be included in the contract in return for an adjustment in the contract price. A promisee, for example, might be willing to pay more for a promise that can be quickly and inexpensively enforced in the event of a dispute. 
context, will not be eliminated by mandating participation in nonbinding CAA programs.

\section{Legal Restrictions}

There are few meaningful legal barriers to contracting for private ADR. ${ }^{89}$ The Supreme Court has interpreted the Federal Arbitration $\mathrm{Act}^{90}$ as evidencing a "liberal federal policy favoring arbitration agreements . . . so that questions of arbitrability must be addressed with a healthy regard for the federal policy favoring arbitration, ${ }^{n 1}$ and absent procedural irregularities most states routinely enforce agreements to arbitrate.

\section{Signaling}

A party may fear that suggesting recourse to private ADR will be interpreted as signaling a weakness in his case, ${ }^{92}$ a desire to avoid delay, or an inability to lay out litigation expenses. A request for $\mathrm{ADR}$, however, may also signal a superior ability to bear risk since the outcome of many ADR processes is more uncertain than a trial outcome. In addition, it has been suggested that certain types of ADR procedures tend to favor the stronger party, ${ }^{93}$ the more

89 Even agreements between an employer and employee to arbitrate all disputes have been held to include claims brought under the Age Discrimination in Employment Act and Title VII of the Civil Rights Act of 1964 despite the pronounced inequality of bargaining power between the parties to the typical employment agreement and the important social policies at stake in discrimination suits. See Gilmer v. Interstate/Johnson Lane Corp., 111 S. Ct. 1647 (1991) (holding that the petitioner's action under the Age Discrimination in Employment Act ("ADEA") was arbitrable under a private agreement to submit all disputes to arbitration); see also Alford v. Dean Witter Reynolds, Inc., 939 F.2d 229, 230 (5th Cir. 1991) (holding on remand after Gilmer that "Title VII claims, like ADEA claims, are subject to arbitration under the [Federal Arbitration Act]," and noting that "any broad public policy arguments against such a conclusion were necessarily rejected by Gilmer").

${ }^{90}$ Pub. L. No. 68-401, 43 Stat. 883 (1925) (current version at 9 U.S.C. $\S \S 1-14$ (1988 \& Supp. III 1991)).

91 Moses H. Cone Memorial Hosp. v. Mercury Constr. Corp., 460 U.S. 1, 24 (1983).

92 See MeIERHOEFER, CAA IN TEN DiST CTS., supra note 4, at 120 (citing attorneys' fear of "electing a procedure that might be construed as a sign of weakness" as a reason for the low participation rate in voluntary court-annexed ADR programs); Brazil, supra note 16, at 333-34 (noting that one of the primary objectives of California's CAA program was overcoming parties' fear that being the first to raise the possibility of settlement would be viewed as a sign of weakness). In addition, a recent study by the Libel Research Project at the University of Iowa found that fear of signaling weakness was one of the main reasons for parties' reluctance to use ADR. See Libel ADR, 10 AlterNATIVES 51, 51 (1992).

${ }^{93}$ For an overview of legal scholarship on cultural and gender bias in arbitration 
educated party, or the party who can afford the most articulate lawyer. ${ }^{94}$

Although the signaling effect of suggesting ADR is likely to be weak, it can be eliminated by having the judge suggest the possibility of ADR at the pre-trial conference. ${ }^{95}$ Each side could indicate its willingness to use ADR on a secret ballot and the judge would suggest that it be used only if both parties requested it. This procedure would remove the negative signal associated with suggesting ADR since a party who did not opt for ADR would not know whether it was requested by his opponent. ${ }^{96}$ Having the trial judge suggest $A D R$ would also avoid another impediment to private ADR, the trial lawyer's fear that suggesting ADR will be interpreted by his client as a signal that he is not a "fighter." ${ }^{n 7}$

On the other hand, when the trial judge suggests private nonbinding ADR, some lawyers may be overly reluctant to refuse. ${ }^{98}$ This may lead to the use of ADR in situations where the parties do

and arguments suggesting that many forms of ADR favor the more powerful party to the dispute, see Jane B. Korn, Changing Our Perspective on Arbitration: A Traditional and a Feminist View, 1991 U. ILL. L. REv. 67. See also Richard Delgado et al., Faimess and Formality: Minimizing the Risk of Prejudice in Alternative Dispute Resolution, 1985 WIS. L. REv. 1359; Trina Grillo, The Mediation Alternative: Process Dangers for Women, 100 YALE L.J. 1545 (1991) (arguing that mandatory mediation in divorce cases may be disadvantageous to women); Lisa G. Lerman, Mediation of Wife Abuse Cases: The Adverse Impact of Informal Dispute Resolution on Women, 7 HARV. WOMEN's L.J. 57 (1984); Janet Rifkin, Mediation from a Feminist Perspective: Promise and Problems, 2 LAW \& INEQ. J. 21 (1984).

94 The effect of litigant wealth on the outcome of the dispute may be pronounced in some CAA programs, particularly in those that do not permit live witness testimony and impose strict time limits on the presentation of counsel, since the rhetorical skills of the lawyer (which may be linked to his hourly rate) may be as or more important than the evidence and the facts. See Eisele, supra note 16, at 4 (arguing that in a court-annexed ADR proceeding "the debating skills of attorneysnot their real-truth revealing, fact-establishing trial skills-are glorified").

${ }_{95}$ There are a number of other ways to eliminate the signaling effect. For example, a number of corporations have signed the CPR Corporate Policy Statement on Alternatives to Litigation. See supra note 83 and accompanying text. Since the statement applies to all disputes, it is unlikely to communicate any information about the strength of the corporation's position in any particular dispute.

${ }_{96}$ Where failure to request ADR sends a negative signal about a party's ability to bear risk, however, this procedure does not necessarily remove that signal, since a party who does request ADR will know whether it was requested by his opponent.

${ }_{97}$ Interview with ADR expert Eric Green, Professor of Law, Boston University School of Law, in Boston, Mass. (Spring 1992).

${ }^{98}$ See, e.g., As Trial Day Dawns, An All-Night Mediation Yields Resolution in a $\$ 1.2$ Billion Gas Case, 9 ALTERNATIVEs 123, 124 (1991) (quoting one lawyer as saying, "'[w]e agreed to [ADR] because we knew the chief judge thought it was a good idea ... I was not going to be the one to say no'"). 
not anticipate joint gains, making any money spent on ADR a deadweight loss.

\section{Transactions Costs}

The transactions costs of entering into a private $A D R$ agreement are low. The American Arbitration Association provides a complementary form book of ADR clauses ${ }^{99}$ and such agreements are summarily enforced by the courts. If it is necessary to obtain confirmation of a private arbitration award in court, some states have an expedited track for rendering such decisions. ${ }^{100}$

\section{Asymmetric Ability to Bear the Costs of Delay}

One of the primary reasons that parties might not enter into an ADR agreement even when it can produce private benefits is that the delay associated with trial is frequently advantageous to one side, ${ }^{101}$ and the party who is better able to bear the cost of delay

99 See American Arbitration Assoc., Drafting Dispute Resolution Clauses: A PRACTICAL GUIDE 33 (1993) (providing standard ADR clauses and describing "some of the ways in which some parties have modified the AAA's time tested standard clause to deal with specific concerns"). In addition, the Center for Public Resources publishes a 22-volume set of ADR practice guides, "[c]overing specialized applications of ADR, including extensive case histories, model procedures and forms, " CPR LEGAL Program, Center for Pub. Resources, CPR Publications I (1993), as well as 23 volumes of model ADR procedures with "[f]orm agreements or guidelines designed for easy application or adaptation to particular dispute resolution needs." Id. at 2.

${ }^{100}$ See, e.g., N.Y. Crv. PRAC. L. \& R. 7510 (McKinney 1980) ("The court shall confirm an award upon application of a party made within one year after its delivery to him, unless the award is vacated or modified ....").

${ }^{101}$ In general, delay favors large, risk-neutral defendants, and hurts small riskaverse plaintiffs, particularly those who have limited access to capital and need money to either pay medical bills in the case of personal injury tort claimants, or to cover current operating expenses in the case of small businesses engaged in contract disputes. In addition, when the expected judgment is large relative to the defendant's assets, delay often gives the defendant time to hide assets.

Corporate defendants who have access to capital often want to defer judgment for as long as possible, particularly when there is a concern that a victory for the plaintiff will either lead to similar suits being filed, or will have res judicata or collateral estoppel effects on pending litigation. Similarly, corporate managers, who often control the pace and conduct of litigation, have an incentive to delay judgment, especially when they have a weak case. In some instances, delay will give managers time to find a new job and/or enter into a long-term employment agreement before their responsibility for the wrongdoing at issue is established. Delay helps managers avoid the full ex post settling up (at least in the period immediately following the wrongdoing) that takes place through the managerial labor market. See Eugene F. Fama, Agency Problems and the Theory of the Firm, 88 J. POL. ECON. 288, 304-05 (1980). 
is usually unwilling to relinquish his strategic advantage. ${ }^{102}$

Delay, like other litigation expenses, imposes costs on the parties; these costs are reflected in the end points of the settlement range at each stage in the litigation process. As long as the arbitration award is non-binding, however, CAA programs will not meaningfully prevent the party better able to bear the cost of delay from exploiting his advantage. Even in programs with postarbitration fee and cost-shifting disincentives to requesting a trial, the party who is better able to bear the costs of delay can still credibly threaten to request a trial; he will simply alter his presentation at the arbitration hearing to minimize the likelihood that he will suffer a fee and cost-shifting sanction should a trial take place. ${ }^{103}$

In addition,

pending litigation need almost never appear as an accrued loss on a balance sheet intended for public disclosure. At most, its existence must be disclosed as a note appended to the financial report without any estimate as to the amount of any likely judgment, and attorneys will often have plausible reasons for not permitting even this small degree of disclosure .... In comparison ... [t]he amount paid in settlement will appear as an accrued loss on the balance sheet....

William E. Nelson, Contract Litigation and the Elite Bar in New York City, 1960-80, 39 EMORY L.J. 413, 433 (1990).

However, delay can strongly favor the plaintiff in situations where the mere existence of the claim creates a cloud on title to an asset of the defendant's. See infra text accompanying notes 128-33. The effect of the cloud is likely to be more severe with respect to individual defendants and small businesses than large corporations with publicly traded shares.

In general, the strength of legal sanctions decreases as delay increases-witnesses' memories fade, evidence disappears, see Richard A. Posner, An Economic Approach to Legal Procedure and Judicial Administration, 2 J. LEGAL STUD., 399, 420 (1973), and non-compensable consequential damages may mount, particularly in situations where the parties' access to capital markets on reasonable terms during the pendency of the dispute is limited. Conversely, delay often strengthens the effect of non-legal sanctions such as damage to reputation or a cloud on title. For a general discussion of nonlegal sanctions and their importance in commercial relationships, see David Charny, Nonlegal Sanctions in Commercial Relationships, 104 HARv. L, REV. 373, 466 (1990).

102 The asymmetric benefit of delay is a barrier to both entering into an agreement to arbitrate once a dispute has arisen, and, in a narrower range of circumstances, to including an arbitration clause in a contract. For example, when a large corporation deals with small suppliers, it may refuse to include an arbitration clause in the contract since it knows that if a dispute arises it will be better able to bear the costs of delay than the small supplier. It should be noted, however, that private ADR processes can entail significant delay, particularly if delay-reducing controls (such as discovery limits and provisions requiring the arbitrator(s) to sit on consecutive days or for a limited period of time) are not included in the arbitration agreement. See infra notes $250-51$ and accompanying text.

${ }^{103}$ See infra note 238 and accompanying text. 


\section{Lawyer-Client Conflicts of Interest}

Another reason that ADR may not be used even in situations where it can produce private benefits is that the decision whether or not to use ADR in aid of settlement is "left in the hands of the people least likely to settle the case-outside legal counsel who depend on protracted litigation for their bread and butter and 'the manager who caused the dispute in the first place." 104 Mandatory non-binding CAA programs, however, do not eliminate this conflict of interest; the same lawyers will advise their clients about whether to accept the arbitration award or request a trial.

A lawyer paid on an hourly basis has a strong incentive to encourage his client to request a trial since most legal fees are earned during discovery and trial. ${ }^{105}$ The hourly-fee lawyer's incentives are unlikely to be affected by a post-arbitration fee and cost-shifting provision. ${ }^{106}$ Consequently, even when participation in an arbitration hearing is mandatory, as long as the arbitration award is non-binding, a potential conflict of interest remains. ${ }^{107}$

In contrast, a contingency-fee lawyer has a strong incentive to encourage his client to accept an arbitration award. ${ }^{108}$ The value of the services that the lawyer must provide prior to arbitration is small. In a CAA jurisdiction, the lawyer's pre-arbitration investment will often be low relative to his expected return if his client accepts the arbitration award. ${ }^{109}$ Although a contingency-fee lawyer always has an incentive to encourage his client to settle, ${ }^{110}$ the

${ }^{104}$ Jacobs, supra note 84 , at F12 (quoting a representative of the American Arbitration Association). This explanation may account for litigators' reluctance to enter into an agreement to arbitrate once a dispute has arisen, but it cannot explain the absence of an ADR clause in a business contract since the lawyer negotiating the transaction and drafting the contract is being paid to avoid disputes.

105 The federal CAA pilot programs each have different limits on pre-arbitration discovery. See supra note 31 .

106 The hourly-fee lawyer's incentives would only be affected by a post-arbitration fee and cost-shifting provision if the lawyer thought that the client would be unable to pay his bill if a post-arbitration fee and cost-shifting sanction was imposed.

${ }_{107}$ Although in a high profile case the lawyer's actions may also be influenced by reputational considerations, these are unlikely to be significant in the types of cases subject to CAA programs' jurisdictional limits.

${ }_{108}$ The lawyer-client conflict of interest created by contingent-fee arrangements is explored in Geoffrey P. Miller, Some Agency Problems in Settlement, 16 J. LEGAL STUD. 189,214 (1987).

${ }^{109}$ In a jurisdiction with post-arbitration fee and cost-shifting, depending on the structure of the contingency-fee contract, the contingency-fee lawyer may have to assume more risk than he would in a trial-only jurisdiction. See infra note 171.

${ }^{110} \mathrm{~A}$ contingency-fee lawyer also has a strong interest in encouraging his client 
fact that an award has been rendered by third-party representatives of the state may make even the most optimistic client more likely to accept the arbitration award.

A recent study of Hawaii's mandatory non-binding tort claim state CAA program ${ }^{111}$ found that the plaintiff's bar, which works primarily on a contingency fee basis, strongly favors the program, while the defendant's bar, which is paid by the hour, strongly opposes it. ${ }^{112}$ Given that tort plaintiffs often perceive a jury trial to be in their best interest, particularly when the defendant has a deep pocket, these findings suggest that a lawyer-client conflict of interest may well exist. ${ }^{113}$

\section{Unequal Bargaining Power in Tort Glaims}

The argument for some form of publicly mandated ADR is stronger with respect to tort claims than contract claims. In the tort context, the parties rarely have the opportunity to bargain before the dispute arises, and, because delay almost always favors the defendant, it is unlikely that they will agree to use private ADR after

to opt for binding ADR.

11 The Hawaii program is mandatory for all tort claims under $\$ 200,000$. A party requesting a trial must improve his position by $15 \%$ at trial or he may have to bear his opponent's actual costs and reasonable attorney's fees. See HAW. ARB. R. 25, 26.

112 Barkai \& Kassebaum, supra note 9, at S65 ("Ninety-one percent of the plaintiffs' lawyers were satisfied with the program, but only $46 \%$ of defense lawyers were satisfied."). The study also reported that when insurance companies hire outside counsel to defend suits subject to the program, they pay them a flat fee for conducting the arbitration and promise to give them a new case to try as soon as they accept a settlement. See id. at $\$ 49 n .38$. This appears to be an attempt to curb the hourly-fee lawyer's incentive to request a trial and conduct discovery, the phase of litigation during which the most hours are billed.

A number of studies of both state and federal CAA programs survey client satisfaction with the arbitration process. See, e.g., MEIERHOEFER, CAA IN TEN DISTRICT COURTS, supra note 4 . Client satisfaction surveys, however, may be misleading, since the typical tort plaintiff is a one-time player who has little or no ability to value a legal claim. In addition, client satisfaction is generally surveyed soon after the award is made, which may simply reflect the average personal injury tort plaintiff's need for cash or exuberance at having "won."

113 To the extent that a lawyer-client principal-agent problem exists with respect to settlement decisions, if information revealed at the hearing gave the client information that his lawyer did not provide about the strengths and weaknesses of his case, requiring parties to participate in an arbitration hearing might be a partial solution to the problem. However, CAA programs, particularly those where all evidence is introduced through arguments of counsel, are a relatively poor way to induce lawyers to reveal such information. Mediation, where the third-party neutral actively participates in the process by questioning the parties and proposing different types of settlements, is far more likely to reveal this type of information. 
a dispute has arisen. However, a CAA program designed to eliminate the effects of the defendant's superior bargaining power in tort claims would have to be both mandatory and binding. Otherwise, the defendant will still be able to make strategic use of his ability to inflict delay. In addition, in jurisdictions with postarbitration fee and cost-shifting provisions, plaintiffs, who tend to be more risk-averse than defendants, may have to bear more risk in order to obtain information through post-arbitration discovery ${ }^{114}$ than they would to obtain the same information through pre-trial discovery in a trial-only jurisdiction.

\section{Justifications for Mandatory Non-Binding CAA Programs}

In situations where the parties could jointly benefit from agreeing to resolve their dispute through ADR but will not agree to do so, mandatory non-binding CAA programs will not enable the parties to realize these potential joint benefits. Consequently, in order to justify government provision of CAA programs it is necessary to identify other benefits that CAA programs might be said to provide and to consider whether the programs can, in fact, achieve these goals. These benefits include relieving docket congestion by reducing the number of nuisance and/or negative expected value suits filed, reducing the private and/or social cost of disputing, reducing delay, and increasing access to the judicial system.

\section{Reducing the Number of Nuisance and Negative Expected Value Suits}

One possible justification for CAA programs is that they will reduce the number of nuisance and negative expected value ("NEV") suits filed. In order to determine the effect of CAA programs on the filing of these suits, it is necessary to consider why such suits are filed, that is, why plaintiffs who file such suits succeed in extracting settlements. There is no generally accepted theory of the nuisance or NEV suit. A number of theories have been developed, but each depends strongly on its assumptions about the sequence in which litigation costs are incurred, the structure of the pre-trial bargaining process, and the amount of information

114 For a discussion of the effect of post-arbitration fee and cost-shifting on riskaverse parties' incentives to request a trial and undertake post-arbitration discovery, see infra notes 230-37 and accompanying text. 
available to the parties. This section considers two explanations for such suits that have gained currency in the legal literature-the asymmetric cost theory ${ }^{115}$ and the asymmetric information theory ${ }^{116}$-and proposes a third explanation: the cloud on title theory. The section concludes that the overall effect of CAA programs on the volume of nuisance and NEV litigation is ambiguous and depends on the details of program structure and the reasons plaintiffs file suit.

\section{a. Asymmetric Cost Theory}

The asymmetric cost theory ${ }^{117}$ defines a nuisance suit as a "suit in which the plaintiff is able to obtain a positive settlement from the defendant even though the defendant knows the plaintiff's case is sufficiently weak that he would be unwilling or unlikely actually to pursue his case to trial. ${ }^{n 18}$ It attributes the plaintiff's ability to extract a settlement to his ability to invoke the legal process at a relatively low cost and inflict substantial litigation response costs on the defendant before being required to bear significant costs himself. When costs are incurred in this sequence $^{119}$ and the plaintiff has such superior bargaining power

115 See D. Rosenberg \& S. Shavell, A Model in Which Suits are Brought for Their Nuisance Value, 5 INT'L REV. L. \& ECON. 3 (1985).

${ }^{116}$ See Lucian A. Bebchuk, Suing Solely to Extract a Settlement Offer, 17 J. LEGAL STUD. 437 (1988) [hereinafter Bebchuk, Suing for Settlement]. For additional discussions of nuisance and/or NEV suits, see Lucian A. Bebchuk, The Credibility and Success of Suits Known to be Made Solely to Extract a Settlement Offer (Nov. 1991) (unpublished manuscript, on file with author); Avery Katz, The Effect of Frivolous Lawsuits on the Settlement of Litigation, 10 INT'L REV. L. \& ECON. 3 (1990); I.P.L. P'ng, Strategic Behavior in Suit, Settlement, and Trial, 14 BELL J. ECON. 539 (1983), criticized in Bebchuk, Suing for Settlement, supra.

117 See Rosenberg \& Shavell, supra note 115 . The authors assume that the parties are risk-neutral, have full information, and select strategies at the outset of the litigation "such that [the] parties would never plan later to act in a way that would lower their expected utility (the interpretation being that they would never make 'threats' which it would not be in their self-interest to carry out)." Id. at 6 . They consider a case in which the defendant must bear significant legal costs in responding to the plaintiff's claim before the plaintiff has to bear substantial costs. They assume that the plaintiff has enough bargaining power to make a one-time take-it-or-leave-it settlement demand to which the defendant must respond by either agreeing to settle or by incurring the cost of responding to the suit. They demonstrate that given these assumptions, it is rational for the defendant to settle at the outset for any amount lower than his litigation response costs and that the plaintiff will find it worthwhile to file suit as long as the cost to him of doing so is less than the defendant's litigation response costs. See id. at 4.

118 Rosenberg \& Shavell, supra note 115 , at 3.

119 There are certain types of lawsuits in which the plaintiff may be able to inflict 
that he is able to make a one-time take-it-or-leave-it settlement demand, ${ }^{120}$ he may be able to extract a settlement just under the defendant's response costs. Given a choice between incurring the cost of responding to the suit or settling for an amount just under his response costs, the rational defendant will agree to settle, even when he knows that the plaintiff's claim is frivolous and will never result in a trial.

In order to explore the effect of CAA programs on the plaintiff's incentive to file this type of nuisance suit, it is necessary to consider the programs' effects in jurisdictions with and without postarbitration fee and cost-shifting provisions and to specify the sequence in which litigation costs are incurred. It is assumed that when a suit that would have been an asymmetric cost nuisance suit in a trial-only jurisdiction is filed in a CAA jurisdiction, costs are incurred in the following sequence: the plaintiff pays a filing fee, the defendant incurs pre-arbitration response costs, the plaintiff incurs pre-arbitration costs, a hearing is held (which is assumed to be costless), and if one party requests a trial, the defendant incurs post-arbitration costs. The plaintiff never incurs post-arbitration costs, since a nuisance suit is, by definition, a claim that he would be unwilling to pursue to trial.

\section{i. Programs Without Post-Arbitration Fee and Cost-Shifting Provisions}

A plaintiff will file an asymmetric cost nuisance suit in a CAA jurisdiction if the cost of doing so ${ }^{121}$ is less than the settlement he

far higher pre-trial costs on the defendant than he will have to bear himself. For example, in tort suits based on claims of design defect, and Title VII or Age Discrimination in Employment Act suits based on statistical inference, plaintiffs may be able to inflict tremendous asymmetric discovery costs on defendants. In addition, in federal cases under $\$ 50,000$, defendants' total litigation expenditures tend to be far higher than plaintiffs' litigation expenditures. See infra text accompanying notes 210-13. In addition, because a nuisance suit plaintiff has no intention of pursuing the case to judgment, he does not need to hire a particularly skilled attorney.

120 The Rosenberg-Shavell assumption that the plaintiff has enough bargaining power to make a one-time take-it-or-leave-it settlement demand corresponds to the assumption that the plaintiff captures the entire bargaining surplus at the time a settlement is reached. It is adopted here solely for expositional simplicity. The sequence of costs can also be viewed as altering the bargaining range faced by the parties, which will in turn affect their ability to extract a larger share of the bargaining surplus.

121 Although for expositional simplicity the cost of filing suit is assumed to be de minimis, in practice it may be significant since it will include not only the filing fee, but also the cost of hiring an attorney to draft a complaint and the cost of serving 
can extract. If a plaintiff with enough bargaining power to make a convincing one-time take-it-or-leave-it settlement demand files suit and makes a settlement demand in an amount under the defendant's pre-arbitration response costs, the defendant, given a choice between defending himself or settling for an amount less than his pre-arbitration response costs, is better off agreeing to settle. The plaintiff may, however, be able to extract an even larger settlement if he has a credible threat to go to arbitration, request a trial, and then demand a settlement from the defendant in an amount just under the defendant's post-arbitration costs. In a CAA jurisdiction without a post-arbitration fee and cost-shifting provision, the plaintiff will have such a credible threat if his pre-arbitration costs are less than the defendant's post-arbitration costs. ${ }^{122}$ If this condition holds and a plaintiff with vastly superior bargaining power makes a one-time take-it-or-leave-it settlement demand at the outset of the litigation process in an amount under the sum of the defendant's pre- and post-arbitration defense costs, the rational defendant will agree to settle. He knows that even if he incurs prearbitration costs defending himself, the plaintiff will continue the suit since the cost to the plaintiff of doing so, his pre-arbitration costs, is less than the settlement he will then be able to extract, an amount just under the defendant's post-arbitration costs. As a consequence, at the outset of the litigation process, given a choice between defending himself or agreeing to settle for an amount less than his total defense costs, the defendant is better off agreeing to settle.

process on the defendant.

122 This condition can be derived through backward induction. Consider how the plaintiff would respond if he filed suit and demanded a settlement but the defendant refused to settle and instead incurred pre-arbitration costs defending himself. At this stage, the plaintiff could either drop the suit or incur pre-arbitration costs, request a trial, and threaten to inflict post-arbitration costs on the defendant. However, the plaintiff's threat to proceed, given that the defendant initially refused to settle, will only be credible if the plaintiff's pre-arbitration costs are less than the amount that he would now be able to extract in settlement were he to proceed, namely an amount just under the defendant's post-arbitration costs. When the parties know at the outset that this condition would hold were the defendant to refuse to settle at the outset (choosing instead to defend himself) and the plaintiff can make a one-time take-it-orleave-it settlement demand at the outset, the plaintiff will demand, and the defendant will agree to pay, an amount just under the sum of the defendant's pre- and postarbitration costs. The defendant knows that he is better off settling for this amount at the outset than he is defending himself prior to arbitration and either settling or defending himself after the arbitration hearing has been held and a trial requested. 
ii. Programs With Post-Arbitration Fee and Cost-Shifting Provisions

In CAA programs with post-arbitration fee and cost-shifting provisions that require the party requesting a trial to improve his position at trial by a specified amount or pay his opponent's postarbitration costs and/or legal fees, ${ }^{123}$ the programs' effect on the plaintiff's incentive to file nuisance suits will also depend on whether the jurisdiction has a "plaintiff-drops" rule-that is, a rule making a plaintiff who requests a trial but later drops or settles his claim liable for the defendant's post-arbitration costs.

In the absence of a plaintiff-drops rule, a post-arbitration fee and cost-shifting provision will not affect the credibility of the plaintiff's threat to impose post-arbitration costs on the defendant-the plaintiff can still drop his claim without a penalty so his incentive to sue will be the same as in a CAA jurisdiction without a post-arbitration fee and cost-shifting provision. In contrast, a CAA program with both a post-arbitration fee and cost-shifting provision and a plaintiff-drops rule may discourage asymmetric cost nuisance suits. Because an asymmetric cost nuisance suit is, by definition, a claim that the plaintiff will never pursue to trial, a plaintiff who must bear the defendant's post-arbitration costs if he drops the claim cannot credibly threaten to impose such costs on the defendant. As a consequence, the largest settlement the plaintiff will be able to extract is an amount just under the defendant's prearbitration costs.

\section{iii. Summary}

Thus, the settlement value of an asymmetric cost nuisance suit in a CAA jurisdiction depends on the plaintiff's ability to credibly threaten to impose post-arbitration costs on the defendant. Consequently, the programs' effect on a plaintiff's incentive to file such suits relative to a trial-only jurisdiction is difficult to predict and will depend on a variety of program features that affect the sequence and amount of the parties' litigation costs-most importantly, the timing ${ }^{124}$ and $\operatorname{cost}^{125}$ of the hearing, the amount of

${ }^{123}$ A typical post-arbitration fee and cost-shifting provision is discussed in Part III, see infra text accompanying note 159, and modeled in the Technical Appendix, infra. For examples of the types of fee and cost-shifting provisions that are common in state CAA programs, see supra note 58.

${ }^{124}$ The timing of the arbitration hearing will have a strong impact on the plaintiff's incentive to sue. Consider a claim that requires each party to incur $\$ 10$ of costs in each of ten periods prior to trial, so that total pre-trial expenditures for each 
party are $\$ 100$.

\begin{tabular}{ccccc} 
Period & $\begin{array}{c}\text { Defendant's post- } \\
\text { arbitration } \\
\text { costs }\end{array}$ & Sign & $\begin{array}{c}\text { Plaintiff's pre- } \\
\text { arbitration } \\
\text { costs }\end{array}$ & $\begin{array}{c}\text { Settlement } \\
\text { amount }\end{array}$ \\
\hline 0 & 100 & $>$ & 0 & 100 \\
1 & 90 & $>$ & 10 & 100 \\
2 & 80 & $>$ & 20 & 100 \\
3 & 70 & $>$ & 30 & 100 \\
4 & 60 & $>$ & 40 & 100 \\
5 & 50 & $<$ & 50 & 100 \\
6 & 40 & $<$ & 60 & 60 \\
7 & 30 & $<$ & 70 & 70 \\
8 & 20 & $<$ & 80 & 80 \\
9 & 10 & $<$ & 90 & 90 \\
10 & 0 & & 100 & 100
\end{tabular}

* The defendant's post-arbitration costs when the arbitration hearing is held in a given period are his total litigation costs less the number of periods elapsed multiplied by $\$ 10$.

** The plaintiff's pre-arbitration costs when the arbitration hearing is held in a given period are the number of periods that have elapsed multiplied by $\$ 10$.

As discussed in the text, in a jurisdiction without a post-arbitration fee and costshifting provision, the plaintiff will have a credible threat to impose post-arbitration costs on the defendant whenever the plaintiff's pre-arbitration costs are less than the defendant's post-arbitration costs. When this condition holds, the plaintiff can extract a settlement just under the sum of the defendant's pre-and post-arbitration costs. When this condition does not hold, the largest settlement the plaintiff can extract is an amount just under the defendant's pre-arbitration costs. Thus, in the example presented above, the plaintiff's incentive to sue would be smallest if the hearing were held in Period 6.

125 If, contrary to the assumption in the text, participation in the hearing did impose costs on the parties, see infra notes $219-20$ and accompanying text, the magnitude of such costs may affect the credibility of the plaintiff's threat to impose post-arbitration costs on the defendant. The condition for determining when the plaintiff will have a credible threat to impose post-arbitration costs on the defendant when the hearing simultaneously imposes costs on both parties can be derived through backward induction. Suppose that the hearing has been held. At this stage, all the plaintiff has to do to impose post-arbitration costs on the defendant is request a trial. This is a costless act so his threat to do so is automatically credible and he will be able to extract a settlement just under the defendant's post-arbitration costs. Now let us ask, if we were at the stage just before the hearing, when would the plaintiff have a credible threat to impose hearing and post-arbitration costs on the defendant? Well, the plaintiff has a credible threat to go forward as long as the cost to him of doing so-the hearing cost-is less than the benefit to him of actually doing so, namely, an amount just under the defendant's post-arbitration costs. Consequently, assuming that the plaintiff can make a one-time take-it-or-leave-it settlement demand, he will demand, and the defendant will agree to pay, an amount just under the sum 
pre-arbitration discovery permitted, ${ }^{126}$ and the relevant fee and cost-shifting provisions and bond-posting requirements. ${ }^{127}$

\section{b. Cloud on Title Theory}

The asymmetric cost theory of the nuisance suit has been criticized on the grounds that "it can at most explain settlement offers up to the amount of [the defendant's] respon[se] costs. ${ }^{n 128}$ It can, however, explain much larger settlements once it is recognized that the mere existence of a legal claim may impose additional

of the defendant's hearing and post-arbitration costs. However, given the assumption that the plaintiff can make a one-time take-it-or-leave-it settlement demand, even before the plaintiff incurs pre-arbitration costs, he will be able to demand, and the defendant will be willing to pay, this amount. Knowing that the consequences outlined above would arise if the conditions outlined above were to hold, if the plaintiff makes a one-time take-it-or-leave-it settlement demand at the outset of the litigation process just under the sum of the defendant's pre-arbitration, postarbitration, and hearing costs, the defendant will agree to settle. These conditions suggest that as the cost of the hearing increases, at some point the plaintiff will no longer have a credible threat to impose post-arbitration costs on the defendant, but that unless the cost is high enough for the threat credibility condition not to hold, the existence of the program will increase the settlement demand the defendant will agree to pay and will therefore increase the plaintiff's incentive to file nuisance suits.

126 The amount of pre-arbitration discovery permitted is particularly important since discovery is the stage in the litigation process that the plaintiff can most easily inflict asymmetric costs on the defendant. See supra note 31 (discussing the programs' limitations on the amount of discovery permitted).

${ }^{127}$ Most CAA programs require a party requesting a trial to post a bond in the amount of the arbitrators' fees. The bond is returned only if the trial outcome is substantially more favorable to the requesting party than the arbitrated outcome. See supra notes 53-54 and accompanying text. In some cases, a bond-posting requirement will make the plaintiff's threat to go to arbitration and request a trial incredible at the outset; it may reduce the maximum settlement the plaintiff can extract and thereby lessen her incentive to file nuisance suits. If, however, the bond-posting requirement does not affect the credibility of the plaintiff's threat-as would likely be the case in a jurisdiction where the arbitration hearing is held after full discovery-it will not affect the amount she is able to extract in settlement and will therefore have no effect on her incentive to file such suits. Although the small size of the bond suggests that it is unlikely to have a significant effect, the effect of a bond-posting requirement can be far larger than the size of the bond itself. For example, in the numerical illustration presented supra note 124, if the arbitration hearing were held in period four, in the absence of a bond-posting requirement, the plaintiff would have a credible threat to impose post-arbitration costs on the defendant and could therefore extract just under $\$ 100$ in settlement. However, if such a program also required a $\$ 21$ bond to be posted, the plaintiff would no longer have a credible threat and would be able to recover just under $\$ 40$. Thus, the effect of the bond-posting requirement on the plaintiff's recovery may, in certain instances be larger than the amount of the bond.

${ }^{128}$ Bebchuk, Suing for Settlement, supra note 116, at 439. 
costs on the defendant regardless of whether the plaintiff would ultimately prevail. ${ }^{129}$ When the filing of a lawsuit creates a "cloud on title" to an asset held by the defendant, the settlement value of the claim is determined not only, or even primarily, by the defendant's litigation response costs, but also by the length of time that the plaintiff can maintain the suit before having a dispositive judgment entered against him, the cost to the defendant of informing relevant third parties ${ }^{130}$ or the market about the strength of the claim, and the cost to third parties of verifying information released by the defendant. ${ }^{181}$ Consequently, it may be rational for the defendant

${ }^{129}$ Clouds on title are common in patent infringement actions, suits alleging that a former employee breached a covenant not to compete, and certain actions to accelerate debt. The cloud is easiest to create when the claim can get past summary judgment, which is most likely when the claim involves a factual dispute. However, in situations where a good deal of discovery will be permitted prior to a decision on the defendant's motion for summary judgment, even in cases where the defendant is likely to prevail on summary judgment, the time between the filing of the claim and the granting of summary judgment may be long enough for the cloud's effect to be strong. It is also important to note that the strength of the cloud may differ from the strength of the claim, in part because while the plaintiff may have the burden of proof at trial, the defendant, in effect, has the burden of proof vis-a-vis third parties during the pendency of the litigation.

${ }^{130}$ This cost is especially large in situations where the defendant might not want to disclose the information needed to reveal the weakness in the plaintiff's claim since doing so might disclose trade secrets or proprietary information.

131 Although Bebchuk explains how the asymmetry of information between the plaintiff and the defendant can explain nuisance and NEV suits, see Bebchuk, Suing for Settlement, supra note 116, when the nuisance value of the claim derives from the cloud on title, it is the informational asymmetry between the parties on the one hand and people who might transact with the defendant on the other that enables the plaintiff to extract a settlement offer. Consider, for example, a patent infringement suit filed against $\mathrm{Mr}$. A who is in the process of negotiating a licensing agreement with Ms. B. After hearing of the action, Ms. B will want information about the merits of the suit. Most likely, she will both request information from Mr. A and undertake an independent investigation. Even if Ms. B ultimately determines that the claim is frivolous, she will now be willing to pay only the original license fee less the costs of determining whether or not the claim had merit. Mr. A loses both the decrease in the contract price as well as the amount he paid to provide Ms. B with information. Consequently, ex ante, $\mathrm{Mr}$. A is better off settling with the person who sued him for any amount less than the cost of responding to the suit plus the cost of Ms. B's independent investigation and any costs that $\mathrm{Mr}$. A himself would have incurred in providing information to $\mathrm{Ms}$. B. In a situation where the delay resulting from the suit might cause the transaction to fall through, Mr. A may even be willing to pay an additional sum to quickly resolve the dispute. Furthermore, to the extent that Ms. $B$ has any residual uncertainty about the strength of the claim, this too will decrease the price she is willing to pay for the license and thus increase the amount that Mr. $A$ is willing to pay to the plaintiff in exchange for a settlement.

In addition, the value of the suit to the plaintiff may exceed its settlement value in situations where the parties are competitors and the existence of the cloud gives 
to settle for an amount that far exceeds his litigation response costs. The time value of a lawsuit may be far higher than the defendant's litigation response costs. As long as the arbitration award is nonbinding, CAA programs, with or without disincentives to requesting a trial, will not deter cloud on title nuisance suits ${ }^{132}$ since their value is determined, in large part, by the length of time the action can be maintained, something that non-binding CAA programs leave unchanged. ${ }^{133}$

\section{c. Asymmetric Information Theory}

The asymmetric information theory defines an NEV suit as a dispute in which the "plaintiff recognizes that the expected value to him of going to trial is negative. This might be the case either because the chances of winning at trial are small (the suit is 'frivolous' [that is, a nuisance suit]) or because the expected

the plaintiff an advantage over the defendant in a product or supply market.

132 Although the magnitude of the effect is difficult to predict, CAA programs may increase the strength of a cloud on title. If the plaintiff prevails at arbitration, this result may be taken as a signal that the claim has merit. In contrast, if the defendant prevails, the cloud may not be either removed or significantly weakened unless the information revealed at the hearing removes the uncertainty that originally created the cloud. When the hearing is held prior to full discovery, the plaintiff may be able to maintain the cloud by insisting that, while the arbitrator might have ruled correctly on the basis of the information presented, his allegations will be borne out when further discovery is completed.

133 One argument against the cloud on title theory is that the market can accurately value a lawsuit. This might be true of a large publicly traded company and routine claims that are small in relation to the corporation's net worth, but it does not apply to large contingent liabilities where there are numerous murky factual issues. In these types of cases, the disclosures made by the corporation tend to be of the form, "the company has meritorious defenses," and nobody knows what types of incriminating documents will turn up in discovery. In addition, in many types of complex lawsuits, a lemons problem is likely to exist. A company in the wrong has no incentive to reveal bad information and a company in the right may be unable to convince others that it is in the clear, even if it voluntarily releases large amounts of information. This may lead the market to discount the company's shares and other transactors to overweigh the existence of the claim in their dealings with the company. Even in situations where the market can accurately value the claim so that a well diversified investor is willing to hold the stock in his portfolio, a relatively riskaverse supplier may be reluctant to enter into a long-term contract with the company, particularly when significant reliance expenditures are involved. Alternatively, the supplier may be willing to contract but only on terms that compensate him for the added perceived risk. Consider a tort suit for a design defect filed against a manufacturer of kidney dialysis machines. If the company were negotiating with a small firm for a contract to produce filters for the soon-to-be-released home version of the machine-a transaction that would require the small firm to retool a plant and make significant reliance expenditures-the small firm might be reluctant to contract. 
judgment is small relative to the expected litigation costs. ${ }^{n 134}$ It attributes the ability of a plaintiff with a NEV claim to extract a settlement offer to informational asymmetries. At the outset of litigation, the plaintiff may have better information about the strength of his claim, the magnitude of his damages, or his expected litigation costs, so the defendant may be unable to determine whether the claim is an NEV suit. The defendant's uncertainty about the plaintiff's expected gain from trial, his inability to eliminate this uncertainty through modest pre-trial expenditures, and his fear that if the case goes to trial his litigation expenses will be high and the judgment large, might lead him to offer some amount in settlement, even in situations where the plaintiff's claim actually has a negative expected value, so the plaintiff would not, in fact, be willing to go to trial if settlement negotiations failed.

The effect of CAA programs on the plaintiff's incentive to file NEV suits is difficult to predict. It will depend on a number of factors that affect the cost to the defendant of eliminating the informational uncertainty, such as the amount of pre-arbitration discovery permitted and the fee and cost-shifting rule in effect, as well as the parties' view of the ability of an arbitration hearing to effectively reveal NEV suits. ${ }^{135}$

134 Bebchuk, Suing for Settlement, supra note 116 , at 437 . In this model, a plaintiff who has superior information about either the expected value of his case or his litigation costs, files a claim and the defendant responds by either ( 1 ) offering some amount in settlement, which the plaintiff must either accept or reject and go to trial; or (2) by refusing to offer anything in settlement, so the plaintiff must either drop the case or go to trial. The possibility of eliminating the asymmetry of information through a pre-trial exchange of information (civil discovery) is not considered; it is assumed that a plaintiff with a positive expected value claim "cannot eliminate the informational asymmetry in any way [short of trial] that is not prohibitively costly," despite the fact that it is in his interest to do so. Id. at $442 \mathrm{n} .8$. Because the asymmetry of information may leave the defendant uncertain as to whether or not the plaintiff has a credible threat to go to trial, it might enable a plaintiff with an NEV suit to extract a settlement, see id. at 440 , since under the model's assumptions, if the defendant either does not offer a settlement, or offers too little and the plaintiff in fact has a positive expected value suit, a trial will take place which will force the defendant to bear significant costs and expose him to the risk of a substantial judgment.

135 The ability of a CAA hearing to effectively reveal NEV suits depends, in large part, on how much information is presented to the tribunal. This, in turn, is influenced by the amount of pre-arbitration discovery permitted, the type of hearing authorized by the local rule, and whether or not witnesses are allowed to testify and be subject to cross-examination. 


\section{i. Programs Without Post-Arbitration Fee and Cost-Shifting Provisions}

A CAA program without post-arbitration fee and cost-shifting will only reduce the number of NEV suits filed relative to a trial-only jurisdiction if the parties think that the arbitration hearing and prearbitration discovery will either reveal NEV suits at less expense than traditional pre-trial procedures, or do so in situations where pre-trial procedures would leave the defendant with enough uncertainty to offer a settlement in a trial-only jurisdiction. If the arbitration process has either of these informational effects, ${ }^{136}$ a plaintiff with an NEV suit may no longer find it worthwhile to sue. ${ }^{137}$ The plaintiff will take into account the possibility that the defendant may refuse to settle until after the hearing is held and that if the hearing reveals that the suit is NEV, the defendant will offer little ${ }^{138}$ or nothing in settlement. ${ }^{139}$ In contrast, if the parties think that the arbitration process is unlikely to reveal NEV suits, CAA programs may slightly increase the plaintiff's incentive to sue. The cost of the arbitration hearing ${ }^{140}$ will increase the defendant's total cost of acquiring information, and may therefore

136 The informational effects of CAA programs are likely to be weak. See infra note 172. If a plaintiff has an informational advantage that he could use to extract a settlement offer in a trial-only jurisdiction, he will be unlikely to either reveal the undisclosed information in an arbitration hearing or reveal it earlier in pre-arbitration discovery than he would in pre-trial discovery. Although it might be argued that because a plaintiff with a positive expected value claim has an incentive to reveal the strength of his case at arbitration, failure to do so will be interpreted by the defendant as a signal that the plaintiff's claim is NEV, there is no reason that the plaintiff's incentive to reveal this information should be any stronger, or his ability to do so any more convincing, than it would be in a trial-only jurisdiction.

${ }^{137}$ Although the possibility of pre-trial discovery is not mentioned in Bebchuk's article, the ability of the plaintiff to extract a settlement there is due, in large part, to the cost (assumed to be trial) of eliminating the informational asymmetry. If pretrial discovery gave the defendant an inexpensive way to eliminate the informational uncertainty, he might prefer to conduct discovery before offering a settlement. If discovery revealed that the plaintiff's probability of prevailing was low, the defendant would then be unlikely to offer a settlement.

${ }^{138}$ Although the hearing eliminates the asymmetry of information, the asymmetric cost theory suggests that plaintiff may nevertheless be able to extract a settlement offer if he can credibly threaten to impose post-arbitration costs on the defendant. See supra note 122 and accompanying text.

${ }^{139}$ Even if the arbitrator makes a small award for the plaintiff, the defendant here can simply request a trial.

${ }^{140}$ See infra text accompanying notes 219-20 (discussing the cost of participating in the arbitration hearing). 
lead him to offer somewhat more in settlement at the outset of the litigation process than he would in a trial-only jurisdiction. ${ }^{141}$

ii. Programs with Post-Arbitration Fee and Cost-Shifting Provisions

The effect of CAA programs in a jurisdiction with post-arbitration fee and cost-shifting may also depend on whether the suit is an NEV suit because litigation costs are high relative to stakes or because the plaintiff's probability of prevailing at trial is low (a nuisance suit).

If the suit is NEV because the plaintiff's costs are high relative to the stakes, the program may increase the plaintiff's incentive to sue. If the parties view the arbitration award as an accurate predictor of the expected trial judgment, the defendant knows that if an arbitration hearing is held he will be better off paying the award than requesting a trial. The trial judgment will be the same as the arbitration award, and he will also have to bear both his own and the plaintiff's post-arbitration costs. In addition, even if the plaintiff would have dropped the suit had the defendant initially refused to settle in a trial-only jurisdiction, he may now continue the suit even if the defendant refuses to settle prior to the arbitration hearing and requests a trial after the hearing has been held. In such a situation, the plaintiff knows that the probability he will have to bear his own costs is very low, so the expected value of going to trial is likely to be positive. Thus, if the suit is a NEV suit primarily because costs are high relative to stakes, and the plaintiff's prearbitration costs are less than the expected arbitration award, his incentive to sue will be greater than in a trial-only jurisdiction. In a CAA jurisdiction, the plaintiff is certain to obtain a recoverythrough settlement at the outset, acceptance of the arbitration award, or trial. This increase in the plaintiff's incentive to sue may, however, be viewed as socially desirable. When the plaintiff's probability of prevailing is high, he has a legitimate entitlement to relief. By making it possible for him to obtain a recovery, the program may serve its intended purpose-increasing access to justice.

The effect of CAA programs on the plaintiff's incentive to file suits that are NEV primarily because the plaintiff's probability of

141 See Bebchuk, Suing for Settlement, supra note 116, at 446 (demonstrating formally that increasing the defendant's costs will "raise the amount that a successful NEV suit will yield"). 
prevailing is low, is more difficult to predict. It will depend, in part, on the plaintiff's estimate of the likelihood that the defendant will offer a pre-arbitration settlement. When the parties believe that the arbitration award is an accurate predictor of the expected trial judgment, a plaintiff with this type of claim will not actually go to either trial or arbitration since he will not obtain a recovery. The likelihood that the defendant will offer a pre-arbitration settlement, and the amount he will offer if he chooses to do so, will depend on his estimates of the cost of participating in the arbitration hearing, the probability that the suit is NEV because the plaintiff's probability of prevailing is low, and the probability that the suit either has a positive expected value or is NEV primarily because costs are high relative to stakes. A defendant will not offer a pre-arbitration settlement when he knows that a claim is NEV because the plaintiff's probability of prevailing is low. However, the defendant's uncertainty about the true character of a claim might lead him to offer a prearbitration settlement. As a consequence, even if the arbitration hearing does accurately reveal NEV suits, the plaintiff's incentive to file suits that are NEV primarily because his probability of prevailing is low will not be eliminated.

If the parties believe that the arbitration hearing is unlikely to reveal NEV suits, the plaintiff's incentive to file such claims may be stronger than in a trial-only jurisdiction, particularly if he is not responsible for the defendant's post-arbitration costs if he requests a trial and subsequently drops the claim. When a defendant makes a settlement offer in face of asymmetric information, he is, in effect, attempting to insure against the risk that, if a trial occurs, litigation expenses will be high and the judgment large. If the parties think that the arbitration process is unlikely to reveal NEV suits, a defendant deciding how much to offer in settlement knows that if the arbitrator makes a large award for the plaintiff, he will either have to pay the award or request a trial. ${ }^{142}$ He knows that in

142 Although the defendant might take into account the possibility that an inaccurate arbitrator might rule in his favor which would force the plaintiff to request a trial, this is unlikely to have a strong effect on either the defendant's willingness to settle or the amount he would offer if he decided to settle. When the arbitration hearing reveals little information, the defendant remains unsure about the strength of the plaintiff's claim. The fact that the plaintiff requested a trial and created the chance that he would have to pay the defendant's costs does not reveal meaningful information unless the jurisdiction has a rule making the plaintiff liable if he requests a trial and subsequently drops the case. Thus, the defendant will be in roughly the same position that he would have been in a trial-only jurisdiction. 
making this decision, he will have to take into account the possibility that the expected trial judgment will be greater than the arbitration award so that he will have to pay both the judgment and, perhaps, the plaintiff's post-arbitration costs. The fee and costshifting provisions increase the expected cost of the defendant's uncertainty. Consequently, he may offer more in settlement than he would in a trial-only jurisdiction, particularly when the hearing is held prior to full discovery. This, in turn, will increase the plaintiff's incentive to sue.

\section{d. Aggregate Effects on the Volume of Nuisance and NEV Suits}

The aggregate effect of CAA programs on the number of nuisance and NEV suits filed will depend strongly on the plaintiff's motive for bringing suit and the details of program design. The effect of programs without post-arbitration fee and cost-shifting provisions on the plaintiff's incentive to file asymmetric cost nuisance suits is difficult to predict; it will depend on the cost of the hearing, the distribution of pre- and post-arbitration costs and how the sequence in which costs are incurred compares to a trial-only jurisdiction. These programs, however, will not reduce and may slightly increase the number of NEV suits based on asymmetric information. The hearings are unlikely either to give the defendant information he would not otherwise have obtained through traditional pre-trial procedures, or to enable him to acquire the same information he would have acquired in a trial-only jurisdiction at a lower cost.

Programs with post-arbitration fee and cost-shifting provisions may decrease the plaintiff's incentive to bring asymmetric cost nuisance suits, but will only do so if they also have a plaintiff-drops rule. Otherwise, their effect will be the same as in a CAA jurisdiction without a post-arbitration fee and cost-shifting provision. However, by increasing the magnitude of the down-side risk from defendant's uncertainty, programs with post-arbitration fee and costshifting provisions may increase the number of suits motivated by the plaintiff's possession of asymmetric information.

CAA programs with or without post-arbitration fee and costshifting provisions are likely to leave the number of suits filed for their cloud on title value essentially unchanged since they do not effect the length of time a suit can be maintained, the primary determinant of the suit's settlement value. 
CAA programs will also affect the volume of litigation even in the absence of asymmetric costs or asymmetric information. Programs without fee and cost-shifting provisions will increase total litigation costs in cases that actually go to trial (by adding an additional layer of costly procedure), making some suits that would have had a positive expected value in a trial-only jurisdiction into NEV suits and thereby decreasing access to justice. In contrast, programs with accurate arbitrators and post-arbitration fee and costshifting provisions may transform some suits that would have had a NEV in a trial-only jurisdiction (because costs were high relative to stakes) into positive expected value suits in a CAA jurisdiction, thereby increasing access to justice.

In sum, CAA programs cannot be justified on the grounds that they are likely to meaningfully reduce the number of nuisance or NEV suits relative to a trial-only jurisdiction. ${ }^{143}$

\section{Reducing Cost and Delay}

A primary goal of CAA programs is to reduce the private and social cost of disputing. ${ }^{144}$ However, a review of the empirical literature on federal CAA programs (which do not have postarbitration fee and cost-shifting disincentives to requesting a trial $^{145}$ ) suggests that there is no conclusive evidence that CAA programs reduce either the private or social cost of disputing.

143 In addition, the option pricing approach to analyzing litigation decisions developed by Bradford Cornell suggests that under a wide variety of program structures and assumptions about the accuracy of arbitration outcomes and awards, such programs may increase the plaintiff's incentive to sue by increasing the option value of his claim. See Bradford Cornell, The Incentive to Sue: An Option Pricing Approach, 19 J. LEGAL STUd. 173, 179 (1990).

${ }^{144}$ In the empirical literature the private cost of disputing is defined as the cost to the parties of resolving the dispute; it includes only attorneys' fees and other direct litigation costs. See, e.g., E. AlLAN LIND, RAND CoRP., ARBITRATING High-STAKES

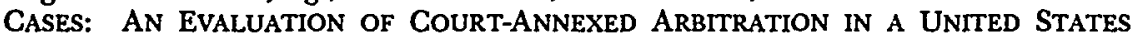
DisTRICT COURT 37 (1990) (measuring private costs by the legal fees and costs paid by each party). Other private costs such as lost productivity when managers spend time preparing for litigation, are not taken into account in these studies. The social (or public) cost of disputing is defined as the per-case cost to the court of processing a legal claim. See, e.g., $i d$. at 40 . This excludes many important components of actual social cost, such as the effect of the program on achieving optimal deterrence of tortious conduct.

145 The only disincentive to requesting a trial is the requirement that the party requesting a trial post a bond in the amount of the arbitrators' fees, which is only returned to him if he significantly improves his position at trial. See supra notes 52-54 and accompanying text. 
One measure of social cost is the per-case processing cost. A recent study of the North Garolina CAA program found that "the average cost to the court of each closed ... [arbitration track] case was $\$ 1209$ and the average cost to the court of each closed control group case was $\$ 1240$," but cautioned that " $[t]$ he difference in cost was not statistically significant." ${ }^{146}$ One district discontinued its program "due to disproportionately high administrative costs ... $14 \%$ of the district's administrative resources were devoted to handling arbitration cases, which represented only $7.2 \%$ of its civil caseload." 147

Even if CAA programs had no effect on the per-case processing cost, they might produce aggregate social cost savings if they reduced the trial rate. There is no conclusive evidence, however, that the programs have reduced the trial rate, ${ }^{148}$ and because so

${ }^{146}$ LIND, supra note 144 , at 40 . The North Carolina program, administered in part by Duke Law School, is the only pilot program that randomly assigns cases to arbitration or control groups.

${ }_{147}$ See Dayton, supra note 16, at 894-95 n.27 (citing Letter from Sylvester A. Markowski to Robert J. Pellicoro (Aug. 11, 1981) (with attached report recommending to drop the court-annexed arbitration in the District of Connecticut) (on file in the University of Iowa College of Law Library)).

148 The study most frequently cited to demonstrate that CAA programs reduce the trial rate is E. ALLAN LIND \& JOHN E. SHAPARD, FEDERAL JUDICIAL CTR., EvALUATION OF CoURT-ANNEXed ARBITRATION IN THREe FEDERAL DISTRICT COURTS (1983). It compared trial rates before and after the institution of CAA programs and concluded that "it [is] fair to assume that the trial rate for arbitration appropriate cases could be as high as 6 or 7 percent in the absence of the rules," but cautioned that "it might not be much higher than the 3 percent we regard as a fair estimate of the rate achieved with an arbitration program." Id. at 140 . Notably, the study did not look at the trial rate in Connecticut, one of the three programs studied, since the program was discontinued. There is some evidence that the Connecticut program had no effect on the trial rate. See Dayton, supra note 16, at $894 \mathrm{n} .27$ and sources cited therein. The RAND study of the North Carolina program which randomly assigned arbitration eligible cases to an arbitration or control group found that there was no statistically significant difference in the trial rate for the two groups of cases, but cautioned that the sample size was too small to permit reliable inferences. See LIND, supra note 144, at 21-22.

In addition, there are a number of reasons to be skeptical of trial rate studies. Under most program rules, parties can make a motion to exempt their case from arbitration for a number of reasons, including that "the case involves complex or novel legal issues ... [or] because legal issues predominate over factual issues." See, e.g., W.D. OKLA. LOC. CT. R. 43(E). Since these are the types of cases that are most likely to go to trial, post-arbitration trial rates should be lower than trial rates in a trial-only jurisdictions even if the programs have no effect on the parties' litigation decisions. Furthermore, trial rates tend to increase as the amount in controversy increases. In CAA jurisdictions, the percent of the arbitration caseload comprised of cases with a particular jurisdictional amount in controversy falls dramatically for claims over $\$ 50,000$. See MEIERHOEFER, TEN DIST. CTS., supra note 4, at 45 tbl. 6 . 
few of the cases subject to the programs would have gone to trial in a trial-only jurisdiction, it would take many years of data to reliably detect changes in the trial rate. ${ }^{149}$

There is some evidence that the programs may slightly reduce the private costs of disputing, but the reductions reported are small, the studies are inconclusive, and the results may be marred by serious response bias. ${ }^{150}$ Furthermore, studies that found some reduction in the private cost of disputing to the plaintiff did not observe any changes in the contingent fee percentages charged by plaintiff's lawyers. This suggests that in the tort context CAA programs may benefit plaintiff's lawyers, but not plaintiffs themselves. ${ }^{151}$

This suggests that in cases where a trial is desired, parties may claim a larger amount in controversy at the outset. In addition, many exemption motions are granted on the grounds that the amount in controversy exceeds the jurisdictional limits. See id. at 45 . It is likely that had these larger cases been subject to the program, the trial rate in CAA jurisdictions would have been higher. See also DONOVAN LEISURE NEWTON \& IRVINE, supra note 76, $\$ 19$ (concluding that "recent quasi-experimental studies focusing on court administered arbitration [in both state and federal courts] have found a similar null result," that is, no effect on the trial rate) (citing DEBORAH R. HENSLER ET AL., RAND CORP., JUdICIAL ARBITRATION IN CALIFORNIA: THE FIRST YEAR xiii (1981) (concluding that "under various assumptions, [California's state CAA program] . . could save as much as $\$ 4$ million annually, could break even, or could result in a $\$ 4$ million increase in court costs") and ROBERT J. MACCOUN ET AL., RAND CORP., Alternative Adjudication: AN Evaluation OF THE NEW JERSEY AUTOMOBILE ARBITRATION PROGRAM (1988)); LIND, supra note 144, at 21-22.

149 This methodological difficulty is pointed out in MEIERHOEFER, CAA IN TEN DIST. CTS., supra note 4 , at $117 \mathrm{n} .69$ (estimating that " $\mathrm{t}$ ] o have an $80 \%$ probability of detecting a two percentage point reduction from a trial rate of $4 \%$, both the arbitration and control samples must exceed 1,000 cases").

${ }^{150}$ The RAND study of the North Carolina program found a statistically insignificant decrease in costs for plaintiffs and a statistically significant (though small) decrease in costs for the defendants, but cautioned that " $[t]$ his cost difference might be due to differences in the cases from which the data were drawn." Id. at 37. However, as the study itself acknowledged, the reliability of cost data is questionable since it is collected through attorney opinion surveys. In the RAND study, for example, $19 \%$ of the attorneys surveyed failed to respond to the attorney survey and of those responding, $29 \%$ did not answer the questions relating to litigation costs. See LIND, supra note 144, at 37.

151 This is not a surprising result since the contingent fee percentage should reflect the probability of going to trial which should not be affected by a non-binding program with no meaningful disincentives to requesting a trial.

There is also some evidence that CAA programs may increase certain components of private cost. For example, a study of the North Carolina program which imposes strict time limits on discovery, found that more motions were filed in cases assigned to the arbitration program. See LIND, supra note 144 , at 36 . In addition, as discussed in Part III, the strict pre-arbitration discovery time limits imposed in some of the programs may increase actual discovery costs. See infra notes 221-28 and accompanying text. 
Even if the data demonstrated that CAA programs reduced the private cost of disputing, the mere fact that actual dispute resolution expenditures are lower does not mean that the high cost of litigation has ceased to impede access to justice. Since only three to four percent of the cases subject to the program would go to trial in a trial-only jurisdiction, it is impossible to assess the programs' effects on access to justice ${ }^{152}$ without information about the programs' effects on settlement amounts. As long as the arbitration award is non-binding, the settlement value of a claim and the range of arbitrated judgments the parties are willing to accept will continue to reflect the potential costs the parties can threaten to inflict on one another regardless of whether or not the costs are actually incurred.

Another goal of CAA programs is to reduce delay. A Federal Judicial Center study of the time from filing to disposition concluded that "speedier dispositions are not an automatic benefit of arbitration programs," 153 and a RAND study found no statistically significant difference in disposition times. ${ }^{154}$ Nevertheless, even if the programs did succeed in reducing average case processing

152 A few of the most commonly cited empirical studies of CAA conclude that they increase access to justice. See LIND, supra note 144, at 62 . However, the definition of increased access is questionable and the data used to support this conclusion are subject to conflicting interpretations. For example, the RAND study of the CAA program in North Carolina hypothesized that the arbitration program might increase access to justice by "enabling those who would otherwise have abandoned their cases to pursue them in the court." Id. at 34-35. It noted a modest increase in the answer rate in cases subject to the program and a slight increase in the number of case filings. However, the study is careful to note that while under the local rules, cases were randomly assigned to either an arbitration or trial track, counsel were not told whether their case was assigned to arbitration until after the answer was filed, although it was possible for an attorney who inquired to obtain such information. Whether these data reflect an increase in access to justice or an increase in nuisance suits cannot be determined. Consequently, caution should be exercised in concluding that this evidence supports the inference that the programs increase access to justice.

153 MEIERHOEFER, CAA IN TEN DIST. CTS., supra note 4, at 97. This study compared the time from filing to disposition in samples of cases from before and after institution of the CAA pilot programs. A small reduction in disposition time was found in three districts, but in seven other districts no statistically significant effect was observed. A Federal Judicial Center study of the original three pilot programs found that while disposition times decreased in two of the three districts, "this is attributable almost exclusively to settlement of cases prior to the arbitration hearing. In the third pilot court, no such effect was found." LIND \& SHAPARD, supra note 148 , at xii-xiii.

154 LIND, supra note 144 , at $41-43$ (finding that arbitration "cases took an average of 285 days to reach termination [and] those in the control group took an average of 282 days," but noting that the difference was not statistically significant). 
times, as long as the arbitration award is non-binding, the party with the superior ability to bear the costs of delay can still threaten to request a trial. Delay is just another cost of litigation. Although CAA proponents would view any reduction in disposition time as evidence of a program's success, regardless of the average disposition time, the parties' relative ability to bear delay will continue to be reflected in the settlement range at each stage of the litigation process and delay will continue to affect access to justice. CAA programs that do not have strong disincentives to requesting a trial do not reduce either the potential litigation costs or the amount of delay that the parties can threaten to inflict on each other, and may well increase such costs particularly when a trial is demanded. ${ }^{155}$ Because it is the specter of these enormous potential costs (rather than whether or not they are actually incurred) that has the effect of limiting access to the justice system, innovations that leave potential costs either unchanged and/or add additional levels of costly procedure cannot increase access to justice-particularly for those of limited means.

\section{The EFfect of CAA Programs on Parties' LITIGATION DECISIONS}

This section uses simulations of a model of the litigation process in a CAA jurisdiction with a post-arbitration fee and cost-shifting provision to explore the programs' effects on parties' litigation decisions. The simulations demonstrate that it is precisely when the arbitration award most accurately reflects the costs of invoking the judicial process that the parties are most likely to accept the arbitrators' decision.

The discussion following the simulations considers the programs' likely impact on discovery and total litigation costs, and explores how each party's wealth, degree of risk aversion, and ability to bear delay affect the programs' distributional consequences. It concludes that as long as the arbitration award is non-binding, inequality of bargaining power as well as the effects of the high cost of litigation and long delays in trying cases will continue to be reflected in the settlement value of a claim, and that as a consequence, CAA programs are unlikely to realize their stated goal of

155 See infra text accompanying notes 214-20. 
increasing access to justice ${ }^{156}$ and may, in fact, decrease access to justice for poorer and more risk-averse litigants.

\section{A. The Sequence of Parties' Litigation Decisions in a CAA Jurisdiction}

The effects of CAA programs on the parties' incentives to sue, settle, accept the arbitration award, or go to trial can be demonstrated by looking at several simulations of the parties' litigation decisions using a model of the litigation process, ${ }^{157}$ standard assumptions about the ratio of costs to stakes, ${ }^{158}$ and a stylized fee and cost-shifting rule ${ }^{159}$ which provides that: (1) if a plaintiff requests a trial and fails to improve upon the arbitration award by $15 \%$ at trial, he must pay the defendant's post-arbitration costs; (2)

${ }^{156}$ See S. REP. No. 416, supra note 11, at 2, reprinted in 1990 U.S.C.C.A.N. at 6804.

157 The formal model is presented in the Technical Appendix, infra. It is based on the standard model of the litigation process. See John P. Gould, The Economics of Legal Conflicts, 2 J. LEGAL STUD. 279 (1973); Posner, supra note 101; Steven Shavell, Suit, Settlement, and Trial: A Theoretical Analysis Under Alternative Methods for the Allocation of Legal Costs, 11 J. LEGAL STUD. 55, 56-58 (1982).

158 The costs-to-stakes ratios used in these simulations are based on data collected by the Civil Litigation Research Project at the University of Wisconsin-Madison. For a discussion of the research methodology employed in the study, see David M. Trubek et al., The Costs of Ordinary Litigation, 31 UCLA L. REv. 72, 94-108 (1983). For a discussion of possible biases in the data set and some interesting adjustments to the data, see Avery Katz, Measuring the Demand for Litigation, 3 J.L. EcoN. \& ORG. 143, 166 (1987) (combining the Wisconsin data on the ratio of total expenditures to average recovery with the Priest-Klein theory of the selection of disputes for litigation, which suggests that the plaintiff is likely to prevail in half the cases that go to trial, and concluding that "20-40 percent is a reasonable range of estimates for the ratio of total expenditures to potential stakes"). For a discussion of the Priest-Klein theory, see George L. Priest \& Benjamin Klein, The Selection of Disputes for Litigation, $13 \mathrm{~J}$. LEGAL STUD. 1 (1984).

${ }^{159}$ Although federal CAA programs do not currently impose post-arbitration fee and cost-shifting sanctions, experimental use of such sanctions in pilot jurisdictions was recommended by the Federal Courts Study Committee. See FEDERAL CoURTS STUDY COMM., supra note 15, at 83-85. Many state CAA programs have fee and costshifting provisions similar to the one considered in the text, see supra note 58 and accompanying text, as did some of the original pilots, see supra note 55 and accompanying text.

At present, the only disincentive to requesting a trial is that the party requesting a trial must post a bond with the court in the amount of the arbitrators' fees which, depending on the district and the number of arbitrators, ranges from $\$ 125$ to $\$ 800$. See supra notes 52-54 and accompanying text. If the party posting the bond improves his position by a specified amount at trial, the bond is refunded; if not it remains in the court treasury. See supra notes 53-54 and accompanying text. In a jurisdiction requiring a bond, it will be rational for a party to request a trial if the arbitration award diverges from her expected post-trial position by more than the amount of the bond. 
if a defendant requests a trial and fails to achieve more than a $15 \%$ reduction in the arbitration award at trial, he must pay the plaintiff's post-arbitration costs; and (3) if both parties request a trial, they each bear their own costs regardless of the trial outcome. ${ }^{160}$ In addition, by illustrating the program's effect on the end-points of the pre-arbitration settlement range, ${ }^{161}$ the range of arbitrated judgments the parties prefer to trial, and the post-arbitration settlement range, the simulations can be used to explore the program's distributional consequences-its effect on the parameters that shape settlement amounts at various stages in the litigation process. ${ }^{162}$

The sequence of the parties' litigation decisions in a CAA jurisdiction is pictured below.

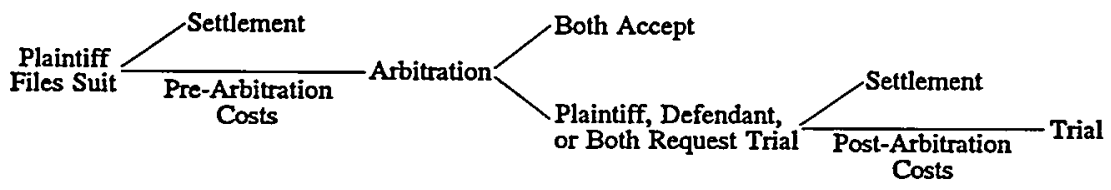

A plaintiff files a claim which is either settled or arbitrated. If it is arbitrated, costs are incurred by both parties, a hearing is held, and

160 The process for requesting a trial is not spelled out in most local rules. For the purposes of this analysis it is assumed that a party desiring a trial notifies the court but not his opponent; otherwise, when both parties want to request a trial a game of "chicken" would likely ensue since each party is better off if his opponent alone requests a trial.

161 At a given stage of the litigation process, the "settlement range" is the range of settlement amounts that both parties prefer to continued participation in the litigation process.

162 Although CAA programs are generally evaluated on the "settlement rate" they are able to achieve, evaluating programs on this basis obscures the distributional concerns that emerge when the programs' effects on the settlement amount are taken into account. In addition, if either the programs' success or individual arbitrators are evaluated on the basis of the settlement rate, the arbitrators' institutional interest may lead them to render those awards that are least likely to lead to a trial request given the parties' degrees of risk aversion and other relevant characteristics rather than the outcomes most closely approximating the trial judgment. A similar argument has been made with respect to judges' interests in increasing the number of case dispositions in case management oriented jurisdictions. See Judith Resnik, Managerial Judges, 96 HARV. L. REV. 374, 427 (1982) ("[J]udges with supervisory obligations may gain stakes in the cases they manage. Their prestige may ride on 'efficient' management, as calculated by the speed and number of dispositions. Competition and peer pressure may tempt judges to rush litigants because of reasons unrelated to the merits of disputes."). 
the arbitrator renders an award. Each party then independently decides whether or not to request a trial, ${ }^{163}$ taking into account his view of the probability that the plaintiff will prevail, the expected trial judgment, his own post-arbitration costs, ${ }^{164}$ and the possibility that he will suffer a fee and cost-shifting penalty if he alone requests a trial and fails to improve his position by $15 \%$ at trial. The plaintiff will compare his post-arbitration position to his expected post-trial position ${ }^{165}$ if he alone were to request a trial, and will only request a trial if, given the arbitration award, his expected post-trial position is better than his post-arbitration position. The arbitration award above which it is rational for the plaintiff to accept the arbitration award and below which it is rational for him to request a trial is a critical point for the plaintiff. ${ }^{166}$ Similarly, the defendant will request a trial if his expected post-trial position is superior to his post-arbitration position, ${ }^{167}$

${ }^{163}$ For an explanation of why, under these assumptions, the parties' decisions about whether or not to request a trial are not interactive, see infra Technical Appendix.

${ }^{164}$ The model used to generate the simulations uses a measure of "costs" that includes both litigation costs, as defined in 28 U.S.C. $\S 1920$ (1988), and attorneys' fees. However, the effects of fee-shifting provisions and cost-shifting provisions are somewhat different. Under the American rule for the allocation of legal fees each side pays its own attorneys' fees, while under the federal rules "costs shall be allowed as of course to the prevailing party unless the court otherwise directs." FED. R. CIV. P. 54(d). In a CAA jurisdiction where only costs are shifted, there will be some instances where the plaintiff prevails at trial but nonetheless has to pay both his own and the defendant's post-arbitration costs since he requested a trial but failed to obtain a judgment $15 \%$ greater than the arbitration award. In contrast, regardless of who requested a trial, a defendant who prevails at trial will never have to pay the plaintiff's post-arbitration costs, though he may have to pay his own costs if he alone requested a trial. In addition, if the defendant requests a trial, he can then make a Rule 68 offer of judgment to the plaintiff. See FED. R. CIV. P. 68 . If the plaintiff rejects the offer and fails to improve his position at trial, he will have to pay the defendant's post-offer costs. See id. Under Rule 68, the plaintiff is not given the option of making such an offer. Thus, as compared to a trial-only jurisdiction, a costshifting rule has a slightly greater negative impact on the plaintiff than it does on the defendant.

${ }^{165}$ The plaintiff's post-arbitration position is the arbitration award less his prearbitration costs. His expected post-trial position when he alone requests a trial is: the probability that he will prevail at trial times his expected recovery if he prevailsnamely, the trial judgment less his post-arbitration costs, less the probability that he will not improve upon the arbitration award by $15 \%$ at trial times the defendant's post-arbitration costs-less the probability that he will lose at trial times the sum of his and the defendant's post-arbitration costs, less his own pre-arbitration costs. See infra Technical Appendix, equation IP.

166 See infra Technical Appendix, equation 2P.

167 The defendant's post-arbitration position is a loss of the arbitration award plus his pre-arbitration costs. His expected post-trial position when he alone requests a 
and will also have a critical point ${ }^{168}$ above which it is always rational for him to request a trial and below which it is always rational for him to accept the arbitration award. When the arbitrator rules in his favor, the defendant will never request a trial.

If the arbitration award is above the plaintiff's critical point and below the defendant's critical point, each party comparing his postarbitration position to his expected post-trial position when he alone requests a trial will opt to accept the arbitration award. The range of arbitration awards that is rational for both parties to accept will be referred to as the "dead zone." 169

Once a trial has been requested, the parties either settle or incur post-arbitration costs and go to trial.

\section{B. Simulations of Parties' Litigation Decisions in a CAA Jurisdiction}

The model used to generate the simulations presented below makes several simplifying assumptions. The parties are assumed to be risk-neutral, and both pre-arbitration and post-arbitration litigation expenditures are assumed to be fixed and known in advance by both parties. The amount of the arbitration award and the trial judgment if the plaintiff prevails are assumed to be normally distributed, ${ }^{170}$ and both parties are assumed to be

trial is a loss equal to the probability that the plaintiff will prevail at trial times his expected loss if the plaintiff prevails at trial-namely, the trial judgment plus his postarbitration costs, plus the probability that he will not improve upon the arbitration award by $15 \%$ at trial, times the plaintiff's post-arbitration costs-plus the probability that he will prevail at trial times his post-arbitration costs, plus his own pre-arbitration costs. See infra Technical Appendix, equation 1D.

168 See infra Technical Appendix, equation $2 D$.

169 If the plaintiff's critical point is greater than the defendant's critical point, as might be the case when the parties hold widely different views about the probability that the plaintiff will prevail or the amount of damages that will be awarded, a dead zone will not exist. In such a case, regardless of the arbitration award, one or both of the parties will request a trial, thereby making any money spent on the arbitration hearing a dead-weight loss. See infra note 199.

170 To say the expected outcome of an adjudicative process is distributed means that if the plaintiff prevails, the amount of the recovery he will be awarded is not certain. Rather, a variety of awards might be rendered, each with a given probability. The assumption that arbitration awards and trial judgments are normally distributed corresponds to the intuition that the adjudicator is most likely to make an award corresponding to actual damages but that the actual award may diverge from this amount with small divergences being more likely than large divergences. A normal 
represented by hourly-fee lawyers. ${ }^{171}$

\section{Convergent Expectations}

The effects of a CAA program with a post-arbitration fee and cost-shifting rule can be seen most clearly by comparing the parties' litigation decisions in a CAA jurisdiction to their decisions in a trialonly jurisdiction ("TOJ") in a case where the parties are risk-neutral and have the same view of the distribution of arbitration outcomes which is also their view of the distribution of trial outcomes. ${ }^{172}$

distribution is pictured below.

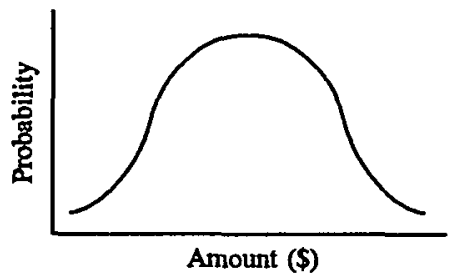

The standard deviation-the parameter that describes the amount of variability (uncertainty) associated with the amount of the arbitration award-used in the simulations is $\$ 40,000$, which means that if the same claim were repeatedly submitted to arbitrators of the same skill, their award would lie between $\$ 20,000$ and $\$ 180,000$ $95 \%$ of the time-that is, within $+/-2$ standard deviations of the distribution's mean (the expected award). The same standard deviation was used for the amount of the trial judgment.

${ }^{171}$ The effects of fee and cost-shifting provisions on the parties' litigation decisions may be different in a tort case if the plaintiff is represented by a contingency-fee lawyer and will depend strongly on the structure of the indemnity in the contingency-fee contract. Although the typical tort plaintiff is risk-averse, the typical contingency-fee lawyer is closer to risk-neutral than his client (since he holds a diversified portfolio of cases) and receives one-third of any settlement or judgment obtained by the plaintiff and nothing if the defendant prevails. If the contingency fee lawyer were permitted to bear the cost of the fee-shifting penalty that was imposed on the plaintiff, it is likely that the contingent fee percentage would increase and that this would become the preferred arrangement since the main reasons for contingency fee arrangements are the plaintiff's inability to finance the litigation and his inability to borrow against the claim from conventional sources. Consequently, the effect of a fee and cost-shifting penalty in this context will depend on whether the plaintiff or his lawyer is made to bear the risk of the penalty. See also Miller, supra note 108, at 189-90 (discussing how contingent fee arrangements may create a conflict of interest between the lawyer and the client with respect to accepting or rejecting a settlement offer).

172 There are, however, reasons to believe that arbitration awards will tend to diverge from trial judgments. In programs where the arbitration hearing is held prior to full discovery, the arbitrator and the judge (or jury) will face different information sets. Even in jurisdictions where discovery is completed prior to the hearing, the information sets are likely to differ since arbitrators may consider evidence that would be inadmissible at trial. Similarly, in jurisdictions where live witness testimony is not 
Numerical Simulation. Consider a claim where the expected damage award if the plaintiff prevails is $\$ 100,000$, total litigation expenditures are $\$ 25,000$ for each party, all in post-arbitration costs, and the parties both believe that there is a $90 \%$ chance that the plaintiff will prevail at arbitration and a $90 \%$ (independent) chance that he will prevail at trial. In this situation, the plaintiff's critical point ${ }^{173}$-the minimum arbitration award he will acceptis $\$ 58,069$ and the defendant's critical point ${ }^{174}$-the maximum arbitration award he will agree to pay-is $\$ 124,876$.

permitted, the arbitrator will not have the opportunity to observe the demeanor of trial witnesses. In situations where one party perceives an adjudicated outcome to be in its best interest from the outset, the attorney may find it desirable to keep certain arguments secret until trial either to achieve an element of surprise or to manipulate the arbitration award to minimize the chance of a post-arbitration fee and costshifting sanction being imposed after trial. Furthermore, even if the information set presented to the arbitrator were identical to the information set presented at trial, the arbitration award may be more uncertain than the expected trial judgment due to the arbitrator's relative inexperience in deciding cases.

Surveys of participants in CAA pilot programs have found that even in jurisdictions where the arbitrator is considered the parties' preferred decision maker, parties believe that judges and juries are better than arbitrators at applying the law. For example, when parties in the Western District of Missouri were asked: "Considering costs, time, and fairness would you prefer to have your case decided by a judge, jury, arbitrator, or makes no difference?," $41 \%$ of those responding to the survey selected the arbitrator and $18 \%$ selected the judge. BARBARA MEIERHOEFER \& Carroll Seron, federal Judicial Ctr., Court-ANnexed ARbitration in the WESTERN DISTRICT OF MISSOURI 42 (1989). But when asked who was most likely to apply the law correctly, $50 \%$ chose the judge and only $7.9 \%$ chose the arbitrator. See id. at 41 . Studies of other pilot jurisdictions report similar responses. See MEIERHOEFER, CAA IN THE E.D.N.Y., supra note 24, at 40; MEIERHOEFER \& SERON, CAA IN THE M.D. FLA., supra note 24, at 43-44; MEIERHOEFER, CAA IN THE M.D.N.C., supra note 26, at 59; MEIERHOEFER \& SERON, CAA IN THE N.D. CAL., supra note 24, at 39-40; MEIERHOEFER, CAA IN THE W.D. OKLA., supra note 24, at 43-44. Survey samples in two jurisdictions were too small to draw meaningful conclusions. See MEIERHOEFER, CAA IN THE D.N.J., supra note 30, at 48-49; MEIERHOEFER \& SERON, CAA IN THE W.D. TEX., supra note 63, at 35-36. In the Eastern District of Pennsylvania, litigants were not asked these questions. See MEIERHOEFER, CAA IN THE E.D. PA., supra note 30 , at 1 .

173 See infra Technical Appendix, equation 2P.

174 See infra Technical Appendix, equation 2D.

In the example presented in the text, the fee and cost-shifting rule under consideration creates a mild pro-defendant bias if the arbitration hearing takes place. If the arbitrator erred $\$ 30,000$ in favor of the plaintiff, it would be worthwhile for the defendant to request a trial since $\$ 130,000$ is greater than the defendant's critical point of $\$ 124,876$. In contrast, if the arbitrator erred $\$ 30,000$ in favor of the defendant, the plaintiff would accept the $\$ 70,000$ award since this is greater than the plaintiff's critical point of $\$ 58,069$. 


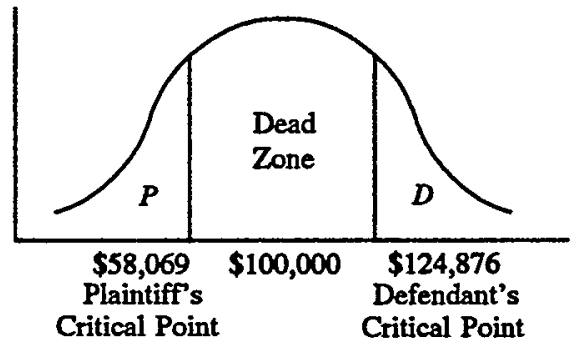

(not to scale)

If the arbitrator rules for the plaintiff and the award falls in zone $P$, which it will with a probability of $14 \%,{ }^{175}$ the plaintiff will request a trial since his expected post-trial position is better than his post-arbitration position. If the award falls in zone $D$, which it will with a probability of $26 \%,{ }^{176}$ the defendant will request a trial since his expected post-trial position is better than his postarbitration position. If, however, the award falls in the "dead zone," which it will with a probability of $59 \%,{ }^{177}$ then neither party will request a trial since each prefers his post-arbitration position to his expected post-trial position when he alone requests a trial. ${ }^{178}$ If the arbitrator rules for the defendant, the plaintiff will request a trial since his expected gain from going to trial is positive. ${ }^{179}$

Having identified the range of arbitration awards both parties would be willing to accept if the arbitration occurs, it is interesting to compare the settlement range at the outset of the litigation process in a TOJ to the settlement range in a CAA jurisdiction. In a TOJ, the plaintiff's expected gain from trial-the minimum amount he would accept in settlement-is his probability of prevailing times the amount of the expected trial judgment, less his litigation costs, here $\$ 65,000 .^{180}$ Similarly, the defendant's

175 See infra Technical Appendix, prob1.

176 See infra Technical Appendix, prob2.

177 See infra Technical Appendix, prob3.

178 When the arbitration award is in the "dead zone," the defendant prefers paying the award to requesting a trial regardless of whether the plaintiff chooses to do so and the plaintiff prefers accepting the award to requesting a trial regardless of whether or not the defendant chooses to do so. The decision of both parties not to request a trial when the arbitration award falls in the dead zone is a Nash equilibrium. See infra Technical Appendix.

${ }^{179}$ At this stage the plaintiff's expected gain from trial is the probability he will prevail times the expected judgment, less the probability that he will lose times the defendant's post-arbitration costs, less his own post-arbitration costs since he will be forced to bear them regardless of the outcome. See infra Technical Appendix, equation P4.5.

${ }^{180}$ See infra Technical Appendix, equation 5P. 
expected loss from trial, the maximum amount he would offer in settlement, is the probability of the plaintiff prevailing times the amount of the expected trial judgment, plus his own litigation costs, here $\$ 115,000 .{ }^{181}$ In a CAA jurisdiction, the minimum the plaintiff will accept at the outset of the litigation is $\$ 80,157^{182}$ and the maximum the defendant will offer is $\$ 103,519 .{ }^{183}$

The settlement range at the outset of the litigation process is narrower in a CAA jurisdiction than in a TOJ. This effect is due, in large part, to the fact that each party's calculation of the expected value of further participation in the litigation process takes into account the possibility that the arbitration award will fall in the dead zone, that both parties will accept it, and that no post-arbitration costs will be incurred, as well as the possibility that his opponent will request a trial which creates some probability that he will not have to bear his own post-arbitration costs. ${ }^{184}$ Whether a narrower settlement range increases or decreases the likelihood of settlement is a matter of some dispute. Some argue that the settlement range constitutes the "bribe" that is to be paid to the parties to induce them to settle: the larger the bribe (that is, the wider the settlement range), the more likely they are to settle. ${ }^{185}$ Others argue that the narrower the settlement range, the less benefit each party gets from holding out for a larger share of the bargaining surplus and the more likely it is that a settlement will be reached. ${ }^{186}$ Consequently, the effect of the programs on the likelihood of settlement at the outset of litigation is difficult to predict.

The assumptions used to generate these results represent a bestcase scenario for a CAA program: the arbitration is free, the parties

181 See infra Technical Appendix, equation 5D.

182 See infra Technical Appendix, equation PG.

183 See infra Technical Appendix, equation DL.

${ }^{184}$ In the numerical simulation presented in the text, the defendant's expected loss decreases by an amount less than the increase in the plaintiff's expected gain since the defendant is somewhat more likely than the plaintiff to request a trial, even when the possibility that the arbitrator will rule for the defendant is taken into account. Whether this shift favors the plaintiff or the defendant depends on their relative bargaining power. If the defendant has all of the bargaining power, the shift favors the plaintiff since it increases the minimum he will accept in settlement. In contrast, if the plaintiff has all of the bargaining power, the shift hurts him since it decreases the maximum settlement offer that he can extract from the defendant.

${ }^{185}$ See, e.g., John C. Hause, Indemnity, Settlement, and Litigation, or I'll Be Suing You, 18 J. LEG. STUD. 157, 158 (1989).

${ }_{186}$ See Richard A. Posner, The Summary Jury Trial and Other Methods of Alternative Dispute Resolution: Some Cautionary Observations, 53 U. CHI. L. REV. 366, 371 (1986). 
are risk-neutral, the parties have the same view of the distribution of arbitration outcomes which is also their view of the distribution of trial outcomes, ${ }^{187}$ all post-arbitration costs and fees are shifted, and the parties do not engage in strategic behavior. However, if the parties do not settle prior to arbitration and the arbitrator rules for the plaintiff, the award will only be accepted $59 \%$ of the time. The $10 \%$ of the time that the arbitrator rules for the defendant, the plaintiff will always opt to request a trial. ${ }^{188}$

This simulation also demonstrates that it will sometimes be in a party's best interest to accept an arbitration award, even if it would have been rational for him to reject a settlement offer in the same amount at the outset of the litigation process. ${ }^{189}$ Thus, the parties' acceptance of an arbitration award that they rejected as a settlement offer during pre-arbitration negotiation does not necessarily mean that the arbitration has provided valuable information which caused the parties to revise their estimates of the plaintiff's probability of prevailing or the distribution of trial outcomes. Consequently, anecdotal accounts which conclude that $A D R$ is a valuable settlement device based on the observation that parties sometimes accept an arbitration award in an amount that was rejected during bilateral settlement negotiations should be viewed with caution.

\section{Divergent Expectations}

\section{a. Mutual Optimism}

It is also important to consider the programs' effects when both parties are overly optimistic about their chances of prevailing at trial. Mutual over-optimism is said to be the most common cause of failure to settle. ${ }^{190}$

187 This means that the arbitration awards are assumed to be as accurate as trial awards.

${ }^{188}$ Note that under the more realistic assumption that the parties will incur half of their costs pre-arbitration and half post-arbitration, in the simulation presented in the text the likelihood that both parties will accept the arbitration award falls to $35 \%$. See infra Technical Appendix, prob3. This decrease in the likelihood that both parties will accept the award is due, in large part, to the fact that post-arbitration costs, which determine the magnitude of the fee and cost-shifting penalty, are now $\$ 12,500$ rather than $\$ 25,000$, so the deterrent to requesting a trial is weaker.

${ }^{189}$ In the example presented in the text, the settlement range at the outset of the litigation is $\$ 80,157$ to $\$ 103,519$, while the range of arbitration awards the parties prefer to requesting a trial is $\$ 58,069$ to $\$ 124,876$.

${ }^{190}$ See Robert Cooter et al., Bargaining in the Shadow of the Law: A Testable Model 
Numerical Simulation. Consider a $\$ 100,000$ claim where total litigation expenditures are $\$ 25,000$ for each party half in pre- and half in post-arbitration costs. The plaintiff believes his probability of prevailing is $90 \%$ while the defendant believes that the plaintiff's probability of prevailing is only $30 \%{ }^{191}$ In a TOJ the plaintiff's expected gain at the outset of the litigation, $\$ 65,000,{ }^{192}$ would be greater than the defendant's expected loss, $\$ 55,000 .^{193}$ A settlement range would not exist and the case would go to trial. In a CAA jurisdiction, the plaintiff's expected gain at the outset of the litigation process is even higher, in this instance $\$ 69,512,{ }^{194}$ and the defendant's expected loss is even lower, in this instance $\$ 49,137 ; ;^{195}$ there is no settlement range so the claim would definitely go to arbitration. However, if this claim went to arbitration, the plaintiff's critical point would be $\$ 72,507 ;^{196}$ he would request a trial whenever the arbitration award is below this amount. The defendant's critical point would be $\$ 46,010 ;{ }^{197}$ he would request a trial whenever the arbitration award is above this amount. Thus, regardless of the arbitration award, a trial will be requested and any money spent on the arbitration hearing is a dead-weight loss. In addition, no postarbitration settlement range would exist regardless of which party requested a trial. ${ }^{198}$

Thus, CAA programs will not create a pre-arbitration settlement range and may not create a post-arbitration settlement range in situations where a settlement range would not have existed in a TOJ

of Strategic Behavior, 11 J. LEGaL STUD. 225, 225 (1982) ("The usual approach to bargaining in the legal setting assumes that trial is caused by excessive optimism on the part of plaintiff and defendant." (citing Gould, supra note 157; Posner, supra note 101, at 419 n.29)); see also Daniel Kahneman \& Amos Tversky, Conflict Resolution: $A$ Cognitive Perspective, in BARRIERs to CONFLICT Resolution (Arrow et al. eds., forthcoming) (discussing the psychological tendency for the parties engaged in a dispute to overestimate their chances of success); George L. Priest, Private Litigants and the Court Congestion Problem, 69 B.U. L. REv. 527, 532-33 (1989).

191 In the simulations of divergent expectations, each party is assumed to calculate his expected gain/loss at each stage of the litigation process as if the other party shared his views. In practice, a party is likely to have some idea of his opponent's expectations, but his ability to accurately assess them will be limited.

192 See infra Technical Appendix, equation 5P.

193 See infra Technical Appendix, equation 5D.

194 See infra Technical Appendix, equation PG.

195 See infra Technical Appendix, equation DL.

196 See infra Technical Appendix, equation 2P.

197 See infra Technical Appendix, equation 2D.

198 The post-arbitration minimum the plaintiff will be willing to accept and the post-arbitration maximum the defendant will offer will depend on who requests the trial because of the potential effects of the fee and cost-shifting provisions. 
due to mutual over-optimism. In addition, because the programs raise the plaintiff's minimum demand and lower the defendant's maximum offer, in some cases where a narrow settlement range would have existed at the outset in a TOJ, no settlement range (either pre- or post-arbitration) will exist in a CAA jurisdiction and there may be no arbitration award that both parties would prefer to trial. ${ }^{199}$ If, however, the arbitration adds information that causes the parties to revise their expectations, it may create a range of arbitrated judgments that the parties would be willing to accept, even where at the outset of the litigation process a settlement range would not have existed in either a TOJ or a CAA jurisdiction due to mutual over-optimism. As they are currently structured and administered, however, CAA programs are unlikely to bring about a significant revision in expectations, particularly when the hearings are held prior to full discovery and the parties' incentives to distort information are taken into account. ${ }^{200}$

199 Consider the claim described in the text but assume that the defendant thinks that the plaintiff's probability of prevailing is $40 \%$. In a TOJ, the plaintiff's expected gain and the defendant's expected loss would be the same- $\$ 65,000-$ so a settlement would be reached. In contrast, in a CAA jurisdiction the plaintiff's expected gain would be $\$ 69,512$ and the defendant's expected loss would be $\$ 60,807$; consequently, a settlement range would not exist and the claim would definitely be arbitrated. If the claim were arbitrated, the plaintiff's critical point would be $\$ 72,507$, and the defendant's would be $\$ 57,006$. Consequently, regardless of the arbitration award, one or both of the parties would request a trial.

If both parties request a trial, the plaintiff's expected gain from further participation in the litigation process is $\$ \mathbf{7 7 , 5 0 0}$ and the defendant's expected loss is $\$ 52,500$, so no post-arbitration settlement range exists. (When both parties request a trial, there are no fee and cost-shifting sanctions regardless of the outcome. Consequently, the plaintiff's expected gain from future participation in the litigation process is $.9(\$ 100,00)-\$ 12,500=\$ 77,500$, and the defendant's expected loss is $.4(\$ 100,000)+\$ 12,500=\$ 52,500)$. If the plaintiff alone requests a trial, his expected gain depends on the arbitration award, but it is, at most, $\$ 77,500$ (assuming that the plaintiff does not suffer a fee and cost-shifting sanction). When the plaintiff requests a trial, the most the defendant expects to lose is $\$ 52,500$, since when the plaintiff requests a trial the defendant's maximum expected loss is the expected trial award plus his own litigation costs. Thus, when the plaintiff requests a trial, there is no post-arbitration settlement range. The same is true when the defendant requests a trial. In that case, the defendant's maximum expected loss from further participation in the litigation process is (from his perspective) $\$ 65,000$ (this is just the expected trial judgment plus the plaintiff's and defendant's post-arbitration costs), but the plaintiff's minimum expected gain from further participation in the litigation process is $\$ 77,500$ (the plaintiff's view of the expected trial judgment less his own postarbitration costs); no post-arbitration settlement range exists, and the parties will go to trial.

${ }^{200}$ There are a number of reasons why neither the information revealed at the arbitration hearing nor the arbitration award are likely to greatly influence the 
b. Mutual Pessimism

It is also interesting to consider the program's effects on a claim where both parties are pessimistic.

Numerical Simulation. Consider a claim for $\$ 100,000$ where each party incurs total litigation expenses of $\$ 25,000$, half in preand half in post-arbitration costs. The plaintiff believes that his probability of prevailing is $55 \%$, and the defendant believes the plaintiff's probability of prevailing is $95 \%$. In a TOJ, the minimum the plaintiff would accept at the outset is $\$ 30,000,{ }^{201}$ and the maximum the defendant would offer is $\$ 120,000,{ }^{202}$ whereas in a CAA jurisdiction, the minimum the plaintiff would accept is $\$ 30,262,{ }^{203}$ and the maximum the defendant would offer is $\$ 116,043 .^{204}$ Given the breadth of these settlement ranges, it is likely that the case would settle regardless of whether it is filed in a TOJ or CAA jurisdiction.

If the arbitration hearing does not cause the parties to revise their expectations, the plaintiff will accept any award above $\$ 36,415^{205}$ and the defendant will agree to pay any award below $\$ 113,822.206$ In contrast, if the arbitration hearing brings the parties' expectations closer together, for example causing the plaintiff to view his probability of prevailing as $70 \%$ and the defendant to view the plaintiff's probability of prevailing as $80 \%$, the plaintiff will now only accept an award above $\$ 55,402^{207}$ and the defendant will only agree to pay up to $\$ 99,037.208$

Thus, in the case of mutual pessimism, the effect of a CAA program on the settlement range at the outset is small and is therefore unlikely to have a significant impact on the parties' litigation decisions. Furthermore, as information revealed at the arbitration hearing causes the parties' views of the plaintiff's probability of prevailing to converge, the dead zone-the range of arbitrated judgments that the parties prefer to trial-will narrow considerably: the more information revealed at the hearing, the

parties' expectations, see supra note 172, particularly when the parties' incentives to distort the information they present at the arbitration hearing are taken into account. See infra note 238 and accompanying text.

201 See infra Technical Appendix, equation 5P.

202 See infra Technical Appendix, equation 5D.

203 See infra Technical Appendix, equation PG.

204 See infra Technical Appendix, equation DL.

205 See infra Technical Appendix, equation 2P.

206 See infra Technical Appendix, equation 2D.

207 See infra Technical Appendix, equation 2P.

${ }^{208}$ See infra Technical Appendix, equation 2D. 
narrower the range of arbitration awards that both parties are willing to accept. The overall effect of the revelation of information on the likelihood of trial as compared to a TOJ is, however, difficult to predict since an increase in the amount of information revealed may make the arbitration award more accurate and therefore more likely to fall within the narrower dead zone; it will also result in a narrower post-arbitration settlement range if a trial is requested.

\section{Factors Not Taken into Account in the Simulations}

In practice, the parameters shaping the settlement amount at various stages of the litigation process and the likelihood that the parties will accept the arbitrator's decision will be affected by a number of factors that were not taken into account in the simulations. ${ }^{209}$ The most important of these factors are related to the cost of the litigation process, the timing of discovery, the initial distribution of information between the parties, the parties' relative bargaining power, and the possibility of strategic behavior.

\section{The Cost of the Litigation Process}

\section{a. Asymmetric Costs in Small Claims}

The simulations assumed that the plaintiff and defendant each incurred the same total costs. In many claims subject to the programs' jurisdictional limits, however, defendants' total costs tend to be far higher than plaintiffs' total costs. Consequently, the magnitude of the fee and cost-shifting sanction facing a plaintiff contemplating requesting a trial will tend to be greater than the magnitude of the sanction facing a defendant. ${ }^{210}$

${ }^{209}$ These factors can, however, be included in the model presented in the Technical Appendix without loss of generality.

Models of the litigation process can also be adapted to take into account the noneconomic factors that may influence the parties' litigation decisions. For example, if a lawsuit is motivated by a desire for revenge, a term representing the benefit to the plaintiff of revenge can be added to the model. This term may or may not be multiplied by the plaintiff's probability of prevailing since forcing one's opponent to appear at the arbitration hearing may be sufficient to produce the desired effect. In the present context, if revenge is considered an important motivation for litigation, CAA programs would most likely increase the plaintiff's incentive to sue since he could drag his opponent into a public forum at a lower cost. In addition, because program rules require the defendant (as opposed to just his attorney) to be present at the arbitration hearing, see, e.g., W.D. MICH. LOC. CT. R. 43(h)(4), the amount of reputational harm the plaintiff can inflict may be greater.

${ }^{210}$ However, if costs are asymmetric primarily during discovery and the hearing 
In cases where less than $\$ 10,000$ is at issue and both lawyers are paid on a hourly-fee basis, the plaintiff usually spends $40.6 \%$ of the judgment on costs while the defendant spends $85 \%$ of the judgment on costs. ${ }^{211}$ In a CAA district, this means that the magnitude of the potential penalty facing a plaintiff who files a claim for less than $\$ 10,000$ and requests a trial may be as much as twice the magnitude of the potential penalty facing the defendant who requests a trial. This improves the defendant's bargaining power and, especially in situations where the plaintiff is more risk-averse than the defendant, makes it unlikely that the plaintiff will request a trial, even when the arbitration award is quite low relative to his view of the expected trial judgment. ${ }^{212}$ The difference between the plaintiff's and the defendant's costs declines as the amount at issue increases. For example, when between $\$ 10,000$ and $\$ 50,000$ is at issue, the plaintiff typically spends $14.23 \%$ of his recovery on legal fees while the defendant typically spends $16.67 \%$ of the plaintiff's recovery on legal fees. ${ }^{213}$ Thus, fee and cost-shifting provisions will systematically disadvantage plaintiffs in small cases, precisely the group of litigants the programs were designed to help.

\section{b. The Effect of the Programs on Parties' Litigation Expenditures}

The simulations assumed that the parties' total litigation expenditures in cases that went to trial were the same in TOJ and CAA jurisdictions, were known by the parties at the time the claim was filed, and were not affected by the amount of the arbitration award. However, to the extent that higher litigation expenditures are associated with either a greater probability of prevailing or a more favorable judgment and tend to increase as the stakes increase, the parties' post-arbitration costs and therefore their total litigation expenditures ${ }^{214}$ are likely to be higher in a CAA jurisdic-

is held after most discovery has been completed, the magnitude of the expected sanction might be the same for the plaintiff and defendant since only post-arbitration costs are shifted.

211 See Trubek et al., supra note 158, at $121 \mathrm{n} .85$.

212 See infra text accompanying notes 230-37 (discussing the effect of plaintiff's risk aversion).

213 See David M. Trubek et al., Civil Lttigation Research Project, 2 Civil LITIGATION RESEARCH PROJECT: FinAL REPORT at II-194 tbl. II-5-H (1983) (ratio of lawyers' fees to recovery, hourly cases only).

214 The precise structure of the post-arbitration fee and cost-shifting rule selected will also affect the parties' pre-arbitration expenditures, but exploring this effect is beyond the scope of this Article. 
tion in cases where a trial takes place. How much higher will be influenced by the size of the arbitration award (since this influences the probability of a post-arbitration fee and cost-shifting penalty).

When a party requests a trial, the post-arbitration fee and costshifting provision increases the stakes relative to a TOJ since the party knows that he will have to pay his opponent's post-arbitration fees and costs if he fails to improve his position by $15 \%$ at trial. This increase in the stakes may lead him to increase his litigation expenditures, at least to the extent that increased expenditures are associated with a greater probability of prevailing and/or a more favorable trial award. In such a situation, his opponent is also likely to increase his expenditures. When one party requests a trial, his opponent knows that there is now some probability that he may not have to bear his own costs; this subsidy gives him an incentive to increase his expenditures. In addition, the party requesting the trial may further increase his expenditures in anticipation of his opponent's respons to the subsidy effect or in response to his opponent's increased expenditures, either because he fears that a failure to do so will decrease his probability of prevailing and/or will result in a less favorable award, or because an action taken by his opponent requires him to respond. ${ }^{215}$

When both parties request a trial, each bears his own costs. Therefore, litigation expenditures should be approximately the same as in a TOJ, apart from the cost of participating in the arbitration hearing. ${ }^{216}$

215 Some cost-increasing expenditures made by one party require increased expenditures by his opponent. For example, if one party calls an additional witness at trial, his opponent will have to spend money preparing and conducting crossexamination. When one party decides to conduct an additional deposition, opposing counsel must be present. See Philip L. Hersch, Indemnity, Settlement and Litigation: Comment and Extension, 19 J. LEGAL STUD. 235, 237 (1990).

216 Despite the fact that the American rule for the allocation of legal costs applies when both parties request a trial, there are a number of reasons why expenditures may nevertheless be different in a CAA jurisdiction. First, the cost of the arbitration hearing will have to be borne by both parties. See infra notes $219-20$ and accompanying text. Second, at the time the suit is filed, the prospect of one-sided fee and costshifting may influence pre-arbitration expenditures. The effect of one dollar of litigation expenditures on the arbitration and trial outcomes may be different and the prospect of obtaining an arbitration award that would lead one's opponent to request a trial (creating the possibility of indemnification) may lead a party to increase his pre-arbitration expenditures. The skill of the lawyer may have an even greater impact on the arbitration award than on the trial judgment even in districts that permit witness testimony since most evidence is still introduced through the arguments of counsel. Similarly, a dollar spent to conceal adverse information in pre-arbitration discovery may have a higher expected return than a dollar spent to conceal 
In sum, CAA programs with post-arbitration fee and cost-shifting rules are likely to either increase or eave unchanged ${ }^{217}$ the parties' litigation expenditures in cases where a trial is requested. ${ }^{218}$ The programs may also increase total dispute resolution expenditures relative to a TOJ in cases that never reach a hearing, as well as in some cases where a hearing is held and the arbitration award is accepted by both parties. The primary reasons for these increases are the cost of participating in the arbitration hearing and the incentives created by the programs' attempts to limit discovery.

\section{The Cost of the Arbitration Hearing}

Although a CAA hearing is likely to be less expensive than a trial on the merits, the hearing may nonetheless impose substantial costs on the parties. ${ }^{219}$ Because these costs do not, for the most

information in a TOJ since if the information remains concealed, one's opponent may have to take additional risk to obtain the desired information in post-arbitration discovery. See infra notes 230-37 and accompanying text.

217 However, as Posner argues, "[a]n increase in [his] opponent's expenditures may induce [a party] to increase his own [expenditures] to overcome their effect . . . [but] it may [also] reduce the value of his own expenditures [so] as to induce him to reduce them." Posner, supra note 101, at 431 .

218 For a formal demonstration that the British Rule for the allocation of legal costs (under which the winner bears his own and the loser's expenses) is likely to increase litigation expenditures under plausible assumptions about the ratio of litigation expenditures to recoveries, see Katz, supra note 158, at 166.

219 The requirement that a person with full settlement authority be present at the hearing means that a representative of each party will lose at least one-half of a day's work. For cases in the diversity jurisdiction, which comprise $39 \%$ to $86 \%$ of the pilot jurisdictions' arbitration case load, see MEIERHOEFER, CAA IN TEN DIST. CTS., supra note 4 , at 43 tbl. 5, at least one party will have to come from out of state, which will impose additional costs.

Most programs require the submission of pre-arbitration case summaries that take time for lawyers to prepare. See, e.g., W.D. OKLA. Loc. CT. R. 43(h). These documents, however, tend to be similar to some filings that are required by local rules for filing a summary judgment motion. Consequently, if a summary judgment motion would have been filed anyhow it may be improper to treat this as an increased cost. In programs that permit the testimony of witnesses, the parties will have to pay witness costs and expert witness fees. These expenses will be duplicated if the case goes to trial. Arbitration testimony is inadmissible at trial except for impeachment purposes, see supra notes $49-50$ and accompanying text, and may only be used to impeach if a transcript of the hearing is made by one of the parties and provided to his opponent free of charge, see supra note 49. Hearings also increase attorneys' fees since lawyers charge more for in-court than out-of-court time. In addition, if CAA programs became widespread, a separate ADR bar might emerge, leading to a situation where a lawyer's preparation for arbitration would, in large part, be duplicated by another lawyer's preparation for trial. Although some argue that this is improbable, the skills required of an ADR lawyer are more similar to the skills 
part, vary greatly with claim size, they impose a greater burden on plaintiffs with small claims-the very litigants the programs are designed to help. In addition, because few of the cases eligible for CAA ever reach trial in a TOJ, a proper assessment of the impact of CAA programs on dispute resolution costs would compare the costs incurred prior to settlement in a TOJ to the costs incurred prior to settlement in a CAA jurisdiction. Although there is no data available on the costs of settlement in either TOJ or CAA jurisdictions, the CAA rules governing discovery suggest that they may increase the cost of pre-settlement discovery. ${ }^{220}$

\section{The Cost of Civil Discovery}

Reducing the cost of civil discovery is a central goal of all CAA programs. However, CAA programs, particularly those with postarbitration fee and cost-shifting provisions, may increase the cost of discovery while reducing the amount of material information exchanged.

In a TOJ, discovery is typically a multi-stage process in which information obtained in one stage is used to shape subsequent requests. During discovery, parties often try to conceal adverse information. Repeated requests are often necessary since "evasive or incomplete responses to discovery probes impede[] discovery by smaller case attorneys in about 40 percent of their cases. ${ }^{221}$ Adverse information is usually revealed only in response to a

required of an appellate rather than a trial lawyer. As noted in Part I, some programs do not even permit the presentation of live witness testimony, relying instead on presentations of counsel. See supra notes 38-39 and accompanying text. Thus, the lawyer arguing at the arbitration hearing may not be the lawyer conducting the trial (and this will become even more likely as the claim size increases) and there will be much double preparation. Furthermore, even if the same lawyer participates in both the arbitration hearing and the subsequent trial, the two events may be years apart, and given the typical lawyer's case load, much preparation will have to be repeated.

${ }^{220}$ However, to the extent that a narrower settlement range decreases the cost of reaching a settlement, the program might reduce settlement costs in cases that settle soon after filing. Similarly, to the extent that a dispute that otherwise would have gone to trial is resolved by acceptance of the arbitration award or settled in light of information that was revealed at arbitration but would have remained hidden during pre-trial discovery, the program may also reduce litigation costs.

221 See Wayne D. Brazil, Civil Discovery: Lawyers' Views of Its Effectiveness, Its Principal Problems, and Abuses, 4 AM. B. Found. RES. J. 787, 834 (1980). This study also found that in one-fourth of the cases where less than $\$ 25,000$ was at stake and the parties settled, lawyers felt there was significant information that their opponent had not yet discovered. See id. at 810-24. 
detailed discovery request where failure to respond would leave the party or his lawyer vulnerable to sanctions.

Most CAA programs attempt to reduce the cost of discovery by imposing strict time limits; ${ }^{222}$ some districts allow only ninety days for the completion of the discovery process. ${ }^{223}$ Discovery time limits create an incentive for lawyers to make broader initial discovery requests than they would in a TOJ. Lawyers fear that if they later need additional information, they may not be able to obtain it since the discovery period will have elapsed. These broader requests are likely to increase response costs and may not reveal much material information. The shortened discovery period may result in fewer rounds of discovery requests, which will limit the opportunity for parties to use the information learned from earlier requests to shape subsequent requests. The programs may therefore increase the amount ${ }^{224}$ and cost of discovery, decrease the amount of material information revealed, and increase a party's ability to hide adverse information. In addition, the programs may increase the benefit of withholding information during prearbitration discovery since the information will never be revealed if the arbitration award is accepted.

Although there are no studies comparing the amount and cost of discovery in TOJ and CAA jurisdictions, a recent study of the North Carolina CAA program, which gives the parties ninety days to complete pre-arbitration discovery, rarely permits extensions, and does not permit any post-arbitration discovery, ${ }^{225}$ suggests that time limits may increase both the private and social costs of discovery. ${ }^{226}$ The study, which compared cases randomly assigned

222 See supra note 31 . The discovery time limits were adopted, in part, because of judges' perceptions that "many lawyers are afraid 'not to discover a case to death' to please their clients," and their hope that "the abbreviated period of discovery in arbitration ... [will force] lawyers to do what their better judgment tells them." MEIERHOEFER, CAA IN THE E.D. PA., supra note 30, at 16-17.

${ }^{223}$ See supra note 31 . One district allows only 60 days. See W.D. TEX. Loc. CT. R. $\mathrm{CV}-87(\mathrm{f})(1)$.

${ }^{224}$ A study of case management in five district courts conducted by the Federal Judicial Center found that " $[t]$ he district with the fastest discovery [that is the shortest discovery time limit] also had the most discovery requests filed per case . . . [and that] the districts with the longest time for discovery are the districts in which the fewest requests were filed." STEVEN FLANDERS, FEDERAL JUdicial CTR., CASE MANAGEMENT AND COURT MANAGEMENT IN UNITED STATES DISTRICT COURTS 27 (1977).

225 See M.D.N.C. LOC. CT. R. 603(a), (d).

226 See MEIERHOEFER, CAA IN THE M.D.N.C., supra note 26, at 23, 41. The private cost of discovery is the cost to the parties. The social cost is the cost to the court of supervising discovery, deciding discovery motions, and, in some instances, imposing 
to either a CAA or a trial-only track, found that more discovery motions were filed in cases assigned to the arbitration track. ${ }^{227}$ Lawyers attributed the increase to the fact that the shortened discovery process gave them less time to reach an accommodation with opposing counsel. ${ }^{228}$

\section{The Parties' Relative Bargaining Power}

The model used to generate the simulations tends to overstate the probability that the parties will accept the arbitration award, particularly when the parties have unequal bargaining power and the possibility of strategic behavior is taken into account. In practice, a party will compare the arbitration award not only to his expected post-trial position, but also to the most favorable postarbitration settlement he can extract from his opponent. Thus, in some instances where the arbitration award falls in the dead zone, a party, particularly one with superior bargaining power, may find it advantageous to request a trial. ${ }^{229}$ Although there are many

sanctions. Two additional social costs of limiting discovery-the possibility that wrongdoing will not be uncovered, and that a less accurate judgment will be rendered-are important but will not be considered here.

227 See id. at 26.

${ }^{228}$ See id. For similar reasons, the programs may also result in an increase in the number of dispositive motions filed. Most local rules provide that any dispositive motions filed after a case has been referred to arbitration are stayed pending the arbitrator's decision. This creates an incentive for the defendant to immediately file any dispositive motions that he can, subject only to the weak constraints imposed by the threat of Rule 11 sanctions. See FED. R. Crv. P. 11.

${ }^{229}$ Modeling this comparison explicitly would entail constructing a mixed strategy game and is beyond the scope of this Article. However, if we assume that after an arbitration hearing is held one party has enough bargaining power to force the other to accept a settlement at the least advantageous point in the post-arbitration settlement range, then it is possible to get a feel for this effect. For example, in the simulation of convergent expectations where the parties incurred all their costs postarbitration, if the arbitration award was just under the defendant's critical point of $\$ 124,876$ (where, under the model's assumptions, the defendant would not request a trial), a defendant with vastly superior bargaining power might decide to request a trial since the plaintiff would be willing to accept anything above his expected gain from trial at that stage of the litigation process given that the defendant requested a trial, in this example $\$ 74,876$. Similarly, if the arbitration award was just above the plaintiff's critical point (so that under the model's assumptions he would not request a trial), the maximum post-arbitration settlement a plaintiff with vastly superior bargaining power could extract from a defendant if he (the plaintiff) requested a trial is $\$ 108,069$. However, because the range of arbitration awards that a party with vastly superior bargaining power would find it desirable to reject in order to obtain a more beneficial post-arbitration settlement is narrower than the dead zone, it remains possible (though unlikely) that both parties will accept the arbitration award. 
sources of unequal bargaining power, the effects of CAA programs on a party's ability to exploit his advantage can be explored by considering a situation where the parties differ in their degree of risk aversion and a situation where they have different abilities to bear the costs of delay.

\section{a. Risk Aversion}

The simulations assumed that both parties were risk-neutral. In practice, however, this is unlikely to be the case, especially in litigation between individuals or between individuals and small businesses. In general, plaintiffs are likely to be somewhat more risk-averse than defendants, particularly in tort cases where an individual who frequently needs the recovery to pay medical bills $^{230}$ is litigating against a large, well-diversified insurance company that is helped rather than harmed by delay. ${ }^{231} \mathrm{CAA}$ programs, particularly those with post-arbitration fee and costshifting provisions, tend to systematically disadvantage the more risk-averse litigant.

Post-arbitration fee and cost-shifting provisions increase the maximum out-of-pocket loss a party may have to bear if he requests a trial. ${ }^{232}$ When a party is risk-averse, the prospect of paying the opposing party's post-arbitration fees and costs has a stronger impact on his litigation decisions than the prospect of being reimbursed for his own post-arbitration fees and costs if a sanction

230 Note that in the tort context, a plaintiff who has actually been harmed by the defendant's actions (and therefore has a relatively high probability of prevailing) is likely to be far more risk-averse than a nuisance suit litigant.

${ }^{231}$ Although courts do award pre-judgment interest, it is usually at below-market rates, which benefits defendants. Also, the passage of time between the commission of a tort and a trial generally favors the defendant since the plaintiff usually has the burden of proof and, over time, witnesses' memories tend to fade and evidence disappears. See Posner, supra note 101, at 420-21.

${ }^{232}$ For example, in a TOJ, the worst-case scenario for our convergent-expectations plaintiff is that he will lose at trial and have to pay $\$ 25,000$ in legal fees. In a CAA jurisdiction, however, a plaintiff must take into account the possibility that if he wins at arbitration and loses at trial, he will have to pay both his own and the defendant's legal fees, here $\$ 50,000$. If losing an additional $\$ 25,000$ would cause the plaintiff to default on his mortgage and lose the credit line for his small business because he could no longer post his house as collateral, he is quite likely to accept a rather low arbitration award no matter how strong his legal entitlement.

Even though CAA programs tend to increase the risk-neutral plaintiff's expected gain at the outset of litigation, the more risk-averse the plaintiff is, the smaller the expected gain will be. In the case of a very risk-averse plaintiff, it is possible that the program will leave him worse off than he would have been in a trial-only jurisdiction. 
is imposed on his opponent. ${ }^{233}$ In addition, because uncertainty itself imposes costs on a risk-averse party, the impact of the programs on a risk-averse party's litigation decisions will depend not only on the magnitude of the potential fee and cost-shifting sanction, but also on his ability to estimate the likelihood that it will be imposed. A party's ability to estimate the likelihood that a sanction will be imposed will depend strongly on his view of the accuracy of arbitration awards and trial judgments, as well as the initial distribution of information between the parties ${ }^{234}$ and the amount of pre-arbitration discovery permitted. ${ }^{235}$

If the jurisdiction has a post-arbitration fee and cost-shifting provision and the arbitration hearing is held prior to full discovery, a party in need of additional information must take a larger financial risk to get it than he would in either a CAA jurisdiction without a post-arbitration fee and cost-shifting provision or a TOJ. In calculating the cost of requesting a trial and conducting further discovery, a party must take into account the possibility that the arbitration award was, in fact, relatively advantageous to him so that the expected trial judgment may be less favorable and may also result in a fee and cost-shifting sanction. This possibility increases the expected cost of post-arbitration discovery and makes it more likely that the arbitrator's decision will be accepted. ${ }^{236}$ Thus,

233 Thus, a risk-averse plaintiff will accept a much lower arbitration award than a risk-neutral plaintiff and a risk-averse defendant will agree to pay a much higher arbitration award than a risk-neutral defendant. The effect of risk aversion on the parties' expected gains and losses at the outset of the litigation relative to a TOJ will depend on the degree of the risk-averse party's risk aversion as well as the risk-averse party's view of the amount of uncertainty associated with the arbitration award and the trial judgment.

234 The initial distribution of information between the parties is even more important in a CAA jurisdiction than in a jurisdiction with the British Rule for the allocation of legal costs. Under the British Rule a party attempting to calculate the expected cost of sanctions need only estimate the magnitude of the sanction and his probability of winning or losing at trial. In a CAA jurisdiction, a party deciding whether or not to request a trial must estimate not only his probability of prevailing but also how much the plaintiff is likely to recover in the event that he prevails.

${ }^{235}$ In the case of a risk-averse plaintiff, the initial distribution of information between the parties and the amount of pre-arbitration discovery permitted will be even more important in a jurisdiction with both a post-arbitration fee and cost-shifting provision and a plaintiff-drops rule. In the absence of a plaintiff-drops rule, a plaintiff who requests a trial, conducts discovery, finds out that his case is weak, and drops his claim, need only bear his own post-arbitration costs, whereas in a jurisdiction with a plaintiff-drops rule, he will also have to bear the defendant's post-arbitration costs.

${ }^{236}$ In addition, post-arbitration fee and cost-shifting provisions, may also increase the expected benefit of concealing information during pre-arbitration discovery relative to either a CAA jurisdiction without a post-arbitration fee and cost-shifting 
although post-arbitration fee and cost-shifting provisions are generally viewed as disincentives to requesting a trial, they are also disincentives to obtaining information through post-arbitration discovery. ${ }^{237}$ This effect is particularly strong when a risk-averse party in need of information is litigating against a risk-neutral party with superior information.

The only way to reduce the effect of post-arbitration fee and cost-shifting provisions on a risk-averse party's incentive to obtain information through post-arbitration discovery and to lessen the importance of the initial distribution of information between the parties, is to increase the amount of pre-arbitration discovery permitted. However, increasing the amount of pre-arbitration discovery permitted would severely limit the programs' ability to reduce litigation costs, even in those cases where the parties opt to accept the arbitration award. In addition, as the amount of discovery conducted prior to the arbitration hearing increases, postarbitration costs tend to decrease since a large proportion of the parties' total litigation costs have already been incurred. Since postarbitration costs determine the magnitude of the fee and costshifting penalty, as these costs decrease, the disincentive to requesting a trial becomes weaker. As a consequence, the dead zone-the range of arbitration awards that both parties prefer to trial-narrows, and the parameters influencing the parties' litigation decisions become increasingly similar to those in a TOJ. In the absence of meaningful disincentive to requesting a trial, the arbitration hearing is simply an additional pre-trial procedure that increases costs and makes justice even less accessible to poorer litigants.

provision, or a TOJ. Because the expected cost of post-arbitration discovery in a CAA jurisdiction with fee and cost-shifting sanctions is greater than both the expected cost of post-arbitration discovery in a CAA jurisdiction without such sanctions and the cost of an additional round of pre-trial discovery in a TOJ, such sanctions decrease the likelihood that a trial will be requested and post-arbitration discovery will take place. This, in turn, increases the expected benefit of concealing information during prearbitration discovery since if a trial is not requested, the information will never be revealed.

${ }^{237}$ Disincentives to conducting civil discovery may have unintended social costs. Adjudicative accuracy or settlement on the basis of full information may be compromised, and, in the tort context, it is possible that fewer instances of wrongdoing will be discovered (constituting both a private and a social cost). 


\section{b. Delay}

The asymmetric benefits of delay are one of the main reasons that parties might not enter into an agreement to resolve their dispute through private ADR even when doing so would create private benefits. However, this does not provide a strong justification for mandatory non-binding CAA programs. As long as the arbitration award is non-binding, the party better able to bear the costs of delay can still exploit his advantage by requesting a trial. Post-arbitration fee and cost-shifting provisions do not strongly constrain a party's ability to inflict delay on his opponent relative to a TOJ. Although such provisions may, in fact, slightly improve the disadvantaged party's bargaining position, the party better able to bear the cost of delay can adjust his presentation at the arbitration hearing to minimize the probability that he will suffer a postarbitration fee and cost-shifting sanction. ${ }^{238} \mathrm{~A}$ party's ability to manipulate the amount of the arbitration award in this manner is subject only to the weak constraints of the programs' "meaningful participation" requirement and the applicable state code of legal ethics. Thus, the programs will not only fail to prevent a party from taking advantage of his opponent's inability to bear the costs of delay, but will also create incentives for parties to present different information at the arbitration hearing than they would at trial.

The incentives for strategic behavior created by the programs suggest that, given the many reasons for the parties to manipulate the evidence presented at the arbitration hearing, the hearings are unlikely to give the parties reliable information that they would not have obtained through pre-trial discovery. Furthermore, the signal generated by the arbitration award, even assuming that it was a perfect reflection of the information presented at the hearing, may be a poor predictor of the trial outcome. Thus, CAA programs will

238 When the plaintiff is better able to bear the cost of delay-for example, where the mere existence of the claim creates a cloud on title to an asset of the defendant's-he can threaten to present a very weak case at arbitration or fail to introduce evidence of some of the damage he suffered (so that he is likely to improve his position at trial and is unlikely to suffer a fee and cost-shifting sanction) unless the defendant agrees to a settlement that reflects his inability to bear the costs of delay. Similarly, when the defendant is better able to bear the cost of delay, he too can threaten to go to arbitration, present a weak case, and request a trial (knowing that the probability of a penalty may be low since the arbitration award is likely to be high), unless the plaintiff agrees to accept a settlement at the outset that reflects his relative inability to bear the costs of delay. 
not meaningfully prevent parties who enjoy strategic advantages in a TOJ from exploiting them in a CAA jurisdiction. As long as the arbitration award is non-binding, even programs with disincentives to requesting a trial will do little to remedy the problems created by parties' unequal bargaining power and the high litigation costs and long delays in the federal courts.

\section{The Differences Between Private ANd Public ADR}

The simulations of parties' litigation decisions in a CAA jurisdiction have illustrated the effects of various program features on the parties' litigation decisions and identified many undesirable distributional consequences of instituting CAA programs. However, the limited promise of the court-connected ADR movement for creating private benefits, improving case management, and furthering other social objectives cannot be fully understood without exploring the differences between private and public ADR and the implications of these differences for assessing the potential of court-connected ADR programs to create private and social benefits.

Private ADR tribunals have a number of features that parties consider important, but which cannot be fully replicated in mandatory non-binding CAA programs. These features include secrecy, informality, speed, finality, the right to select a trier of fact with specialized knowledge or expertise, and, in some trade industry arbitration, the ability to specify the rule of decision that will be used to resolve the dispute as well as the avoidance of litigation costs. In addition, in commercial transactions, ADR provisions have important functions other than merely specifying the forum and means of resolving disputes; ${ }^{239}$ in many transactions they can be used to create value by reducing transaction and negotiation costs, reducing risk, and broadening the range of credible substantive commitments available to the parties. They may also enable the parties to secure the benefits of both legal and extralegal sanctions.

239 The idea that different types of disputes are best suited to different types of dispute resolution tribunals is a central premise of Multidoor Courthouse programs, a popular type of court-connected ADR. Interview with Frank E.A. Sander, Professor of Law, Harvard Law School, in Cambridge, MA (Mar. 30, 1993). 


\section{A. Features of Private $A D R$ Tribunals}

\section{Secrecy}

One of the most important features of private ADR is the secrecy of both the proceedings and the outcome. Advertisements for private ADR providers tend to emphasize secrecy. ${ }^{240}$

Secrecy can affect both the likelihood of settlement and the settlement value of a claim. In situations where a party is frequently involved in litigation and has an interest in having a reputation as a hard bargainer, secrecy may remove the benefit of being perceived as a hard bargainer in a particular case and make him more likely to settle. Conversely, a party who would have settled to avoid revelation of proprietary information in the absence of an ADR agreement may refuse to settle when such an agreement exists, secure in the knowledge that the proceedings will remain secret. $^{241}$

An additional benefit of secrecy is that it enables the litigants to minimize the damage to their reputation. Although this might not be important in the context of smaller claims to the extent that the existence of a dispute may affect a party's access to capital during the pendency of the dispute, it is an important advantage of private ADR. ${ }^{242}$

Federal court-connected ADR programs cannot offer parties the same degree of secrecy as private ADR programs. Even in courtconnected ADR proceedings where the hearing is closed to the public so that the information revealed in the proceeding is kept private, the existence of the dispute and the allegations in the pleadings are a matter of public record. ${ }^{243}$ In addition, although

${ }^{240}$ See Gail D. Cox, The Best Judges Money Can Buy, NAT'L L.J., Dec. 21, 1987, at 1, 24 (reporting that according to the president of Judicate, Alan Epstein, "[c]onfidentiality is part of what his firm sells $s^{\prime}$ ).

241 The secrecy of the proceedings also eliminates the need for protective orders, which are difficult and costly to obtain. It is important to note, however, that depending on the type of claim at issue, the secrecy of private ADR proceedings may create social costs. For example, it may delay information about a defective product from reaching consumers.

242 The effect of the mere existence of a dispute on a party's access to capital during the pendency of a dispute is one of the main reasons that the diamond industry continues to prefer to resolve its disputes through its private ADR system. See Lisa Bernstein, Opting Out of the Legal System: Extralegal Contractual Relations in the Diamond Industry, 21 J. LEGAL STUD. 115 (1992).

${ }^{243}$ In addition, in some programs, such as mandatory non-binding CAA, if the parties accept the arbitration award it is entered as a judgment of the court and is 
the Sixth Circuit has held that summary jury trials may be closed to the public, ${ }^{244}$ the constitutionality of closing other types of federal court-connected ADR proceedings to the public has not yet been considered by any federal court. ${ }^{245}$

\section{Informality}

According to ADR professionals, informality is an important reason that parties opt for private ADR. ${ }^{246}$ Informal processes are said to be better than formal adversary proceedings at preserving ongoing business relationships. However, it is precisely in the relational contract setting, where the parties have dealt with each other on a repeat basis over a long period of time and know the types of disputes that are most likely to arise, that the barriers to contracting for private ADR are the lowest, the benefits from doing so are largest, and the parties can most easily select a trier of fact who they feel will justly and amicably resolve any dispute that may arise. In such a situation, failure to include an ADR provision in a contract is likely to reflect a deliberate choice made by the parties and to signal their preference for traditional adjudication should a dispute arise that cannot be amicably resolved.

The ability of court-connected ADR proceedings to fully capture the benefits of informality that are available when the parties opt to use relatively informal private ADR processes is limited. First, the success of most informal dispute resolution processes is due, in large part, to the fact that parties consent to their use. An informal

therefore a matter of public record.

244 See Cincinnati Gas \& Elec. Co. v. General Elec. Co., 854 F.2d 900 (6th Cir. 1988), where the court held that "the first amendment right of access does not attach to summary jury trial proceedings," since

there is no tradition of access to summary jury trials or to other recognized settlement devices, ... . [and] public access does not have a significantly positive role in the functioning of the summary jury trial because the proceeding is non-binding and has no effect on the merits of the case other than settlement.

Id. at 902 .

${ }^{245}$ For a general discussion of the importance of secrecy and the issue of public access to court-connected ADR proceedings, see CPR Legal Program Annual Meeting, 9 ALTERNATIVES 147, 150-51 (1991).

${ }^{246}$ Interview with Frank E.A. Sander, Professor of Law, Harvard Law School, in Cambridge, MA (Mar. 30, 1993); Interview with Eric Green, Professor of Law, Boston University School of Law, in Boston, MA (April 1993). 
process is unlikely to lead to a consensual settlement when one party does not wish to participate. Second, the history of agency adjudication suggests that court-connected ADR programs and proceedings are likely to become increasingly formal and complex. ${ }^{247}$ CAA programs, for example, are designed to be far less formal than traditional adjudication; yet CAA hearings have an adversary structure and local arbitration rules are far more complex ${ }^{248}$ than the procedural rules of many private ADR providers. $^{249}$

247 The history of agency adjudication under the Administrative Procedure Act, 5 U.S.C. $\$ \S 551-559$ (1988), suggests that public programs are unlikely to remain informal. Agency adjudication was originally intended to be less formal and adversarial than traditional adjudication. Over time, however, numerous due process challenges have been brought and the hearings have become increasingly similar to traditional adjudication. In an attempt to recapture the benefits of relatively informal proceedings, the recently passed Administrative Dispute Resolution Act, 5 U.S.C.A. \$ 571 (West Supp. 1993), directs each agency to designate an ADR official to explore the possibility of substituting agency ADR for agency adjudication whenever possible. For a discussion of the considerations leading to the passage of the Administrative Dispute Resolution Act, see Administrative Dispute Resolution Act, Pub. L. No. 101552, § 2, 1990 U.S.C.C.A.N. (104 Stat.) 2736, 2736 (1990) (noting that "administrative procedure ... is intended to offer a prompt, expert, and inexpensive means of resolving disputes as an alternative to litigation in the Federal courts .... [However,] administrative proceedings have become increasingly formal, costly, and lengthy resulting in unnecessary expenditures of time and in a decreased likelihood of achieving consensual resolution of disputes") (codified at 5 U.S.C.A. $\$ 571$ note (West Supp. 1993) (Congressional Findings)).

248 Many legal issues regarding the implementation of CAA programs continue to arise and have yet to be definitely resolved. See, e.g., McHale v. Alcon Surgical, Inc., No. 91-7445, 1992 U.S. Dist. LEXIS 6544, at *1 (E.D. Pa. Apr. 29, 1992) (holding that whether parties have participated in a CAA hearing in a "meaningful manner" is for the court to decide). But see Gilling v. Eastern Airlines, Inc., 680 F. Supp. 169, 171 (D.N.J. 1988) (concluding that the local arbitration rule "appears to place the determination of meaningfulness entirely in the hands and discretion of the arbitrator, without being subject to district court review"). See also Ewell v. Allstate Ins. Co., No. 91-5858, 1992 U.S. Dist. LEXIS 2565 (E.D. Pa. Feb. 28, 1992) (considering whether arbitrators in a CAA program have the authority to award punitive damages); Action Orthopedics, Inc. v. Techmedica, Inc., 775 F. Supp. 390, 390-91 (M.D. Fla. 1991) (considering whether or not a party is entitled to demand a trial de novo as to a portion of an arbitration award, and concluding that he may not); R.J. Reynolds Tobacco Co. v. Southern Ry. Co., 110 F.R.D. 95 (M.D.N.C. 1986) (discussing defendant's motion for leave to amend his answer under F.R.C.P. 15(a) when the case had already been set for arbitration).

${ }^{249}$ Compare M.D.N.C. LOC. CT. R. 601-608 with JUDICATE R.P., supra note 71. 


\section{Finality and Reduction of Delay}

Although many private ADR processes are non-binding and some disputes take as long to resolve through arbitration as litigation, ${ }^{250}$ parties who value finality and prompt resolution of disputes can contract for binding arbitration, strict discovery time limits, and a fixed time for conduct of the hearing and the announcement of the judgment. ${ }^{251}$ By providing for finality and certainty as to the duration of the dispute, private ADR agreements can affect the potential costs that the parties can threaten to inflict on one another in the event of a dispute. Perhaps the most significant effect of an agreement to use binding private ADR is that it breaks the shadow of the law-it ensures that the parameters shaping the settlement range are determined by a set of variables that the parties prefer to those provided by the legal system.

\section{Consent}

Another important difference between private ADR tribunals and mandatory CAA programs is that private ADR tribunals hear cases with the consent of the parties. Although "consent" influences the dispute resolution process in a myriad of ways, ${ }^{252}$ at a minimum it is a signal that both parties perceive a nonlitigated solution to be in their best interest and are willing to consider compromise. Contrary to the arguments of ADR proponents, it may not be that ADR processes induce the parties to settle, but rather that parties who are inclined to settle are more apt to choose ADR as a method of dealing with their dispute. It is therefore unlikely that mandatory non-binding court-annexed ADR programs will resolve disputes as successfully and amicably as private ADR programs selected by the parties. Although participation in CAA programs and other types

${ }^{250}$ Private ADR is not necessarily cheaper or faster than litigation. See, e.g., Herbert M. Kritzer \& Jill K. Anderson, The Arbitration Alternative: A Comparative Analysis of Case Processing Time, Disposition Mode, and Cost in the American Arbitration Association and in the Courts, 8 JuST. SYS. J. 1, 18 (1983) (concluding that "[o]ne does

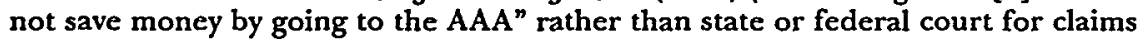
above $\$ 5,000$ ).

251 For examples of ADR provisions that are designed to reduce cost and delay, see AMERICAN ARBITRATION ASSOC., supra note 99, at 22-27.

252 For example, when the parties choose a neutral decisionmaker with expertise in the area of the dispute, they may be more willing to defer to his opinion, particularly if he has an established reputation in the relevant business community so that rejection of his award would be viewed by market transactors as opportunistic behavior. 
of court-connected ADR could be made voluntary, studies of voluntary state court-connected ADR programs show low participation rates, ${ }^{253}$ as do studies of the federal programs which permit any claim to be submitted to CAA with the consent of the parties. ${ }^{254}$

\section{Summary}

Thus, many aspects of private ADR tribunals that make them attractive to disputants such as secrecy, informality, finality, and reduction of delay are not fully replicated in mandatory non-binding CAA programs, and may not be possible to fully replicate in other types of court-connected ADR programs. In addition, many of the private benefits created by ADR agreements and provisions cannot be created by mandating participation in a non-binding courtconnected ADR programs since ADR provisions have many functions apart from specifying the forum for resolving a particular dispute.

\section{B. Functions of $A D R$ Provisions}

The private benefits available from private ADR go beyond the savings in litigation costs and the reduction of delay that are said to be the primary private benefits of publicly mandated CAA programs. As the name ADR suggests, arbitration, mediation, and other processes conducted by third-party neutrals are viewed primarily as dispute resolution techniques, and are implicitly conceived of as alternatives to trial. Viewing ADR processes as dispute resolution techniques yields insights into why parties enter into ADR agreements after a dispute has arisen (ex post ADR), but obscures many of the reasons that ADR clauses or provisions ${ }^{255}$ are included in commercial contracts (ex ante ADR). In many transactional settings, ex ante $A D R$ provisions can be used as

253 See Pearson, supra note 16 , at 426.

254 See supra notes 63-67 and accompanying text.

255 The term "ADR clause" is used to refer to an agreement to submit all disputes that arise under the contract to a particular ADR tribunal. The term "ADR provision" is used to refer to a more narrowly drafted $A D R$ clause, such as a provision which requires certain factual issues related to performance of a particular clause of a contract to be submitted to a third-party neutral or an ADR tribunal. See, e.g., AMERICAN INST. OF ARCHITECTS, AIA DOCUMENT A107 (8th ed. 1978), discussed in E. ALLAN FARNSWORTH \& WILlIAM F. YOUNG, CASES AND MATERIALS ON CONTRACTS, $657-58$ (4th ed. 1988). 
effective substitutes for detailed contractual language or as ways of enabling parties to contract with respect to an alternative default regime (that is, a set of default rules) that they prefer to the rules provided by the state. Such provisions can also be used to prevent or constrain strategic behavior during the course of contractual performance and to obtain the benefits of both legal and extra-legal sanctions. ${ }^{256}$

\section{ADR Clauses and the Creation of Value}

When parties can agree on an acceptable neutral, the inclusion of a narrowly tailored $\mathrm{ADR}$ provision can defer, and therefore reduce, the cost of negotiating and drafting clauses dealing with remote contingencies. ${ }^{257}$ Such $\mathrm{ADR}$ provisions can also reduce the likelihood of both negotiation breakdown ${ }^{258}$ and the possibili-

${ }^{256}$ In some types of transactions, ADR provisions designating a "wise man" to resolve certain types of disputes can also be used to enable parties conducting discrete arms-length transactions to capture many of the benefits of long-term relational transactions. For example, in transactions between strangers, "good faith," "best efforts," and other clauses designed to give the parties flexibility, often have little effect on parties' actions due to the uncertainty and expense of enforcing them, yet their effectiveness can be enhanced by designating a "wise man" whose opinion both parties respect to decide issues arising under these clauses.

${ }^{255}$ When the determination of the parties' rights and duties under the contract in the event of a remote contingency is left to a third-party neutral whose determination the parties think will replicate the bargain they would have reached had they spent the time and money to negotiate and draft a specific contractual provision (their "hypothetical bargain"), the parties will not have to incur the transaction costs of actually reaching an agreement. In addition, if the contingency occurs, they still have the opportunity to renegotiate their agreement, and the transaction costs of doing so may be smaller since neither side will be able to threaten litigation. In such a situation, if a negotiated outcome is reached, the outcome is less likely to simply reflect the parties' relative ability to bear the cost and delay of a court proceeding than it would have been in the absence of the clause. For a more complete discussion of how ADR provisions can be used to fill contractual gaps, see Lisa Bernstein, Social Norms and Default Rules Analysis, 3 S. CAL. INTERDISC. L.J. (forthcoming November 1993) (working title).

${ }^{258}$ Such clauses can also be used to reduce the potential value left "on the table" in the negotiation of complex contracts by solving a central problem identified in the negotiation analysis literature, the so-called "negotiator's dilemma." The negotiator's dilemma arises when a strategy of mutual cooperation would produce the largest gains for the parties but would not be undertaken since it requires each party to reveal information that could be used to his disadvantage by his opponent if his opponent "defects" and acts uncooperatively. In such situations, the parties can work out the rest of the transaction and include a provision in their contract which designates a "wise man" (a third-party neutral they both respect) to write the clause at issue based on the confidential submissions of each party. For a description of the negotiator's dilemma and an overview of the emerging literature on negotiation 
ty that the transaction will not be consummated by the relevant deadline. ${ }^{259}$ In addition, in some contexts, ADR provisions designed to ensure that disputes are resolved quickly can reduce the actual damage suffered by the promisee in the event of breach, since a quick resolution of the dispute may prevent some consequential damages (both compensable and noncompensable) from arising. ${ }^{260}$

In a more limited range of circumstances, $A D R$ clauses can create value by reducing certain types of risk. For example, in a situation where the risk of inadvertent breach is large and performance cannot be specified with sufficient precision at a reasonable price, the inclusion of an ADR provision-one that provides for either arbitration and cure or enables the promisor to get an advance determination as to whether a particular action would constitute breach-can reduce the amount of risk borne by the promisor. A clause enabling the promisor to determine in advance what constitutes breach removes the uncertainty of how a court, necessarily viewing his actions ex post, would classify his behavior. An arbitrate-and-cure provision enables the promisor to make a deliberate breach or perform decision. ${ }^{261}$ These types of provisions also benefit the promisee since as the amount of risk borne by the promisor decreases, so does the contract price. ${ }^{262}$ In addi-

analysis, see generally James K. Sebenius, Negotiation Analysis: A Characterization and Review, 38 MGMT. SCI. 18, 30 (1992).

259 In attempting to value the "benefit" of reducing the likelihood of negotiation breakdown or the possibility that the transaction will not be consummated by the relevant deadline, it is important to take into account that the value of this "benefit" to the transactors may be different from the value of this "benefit" to the transaction when transactors' nonpecuniary risk aversion is taken into account. For example, when a high-level corporate manager negotiates a contract, he may be more concerned about failure to close a deal that will bring him intra-organizational prestige than he is about the expected cost to the corporation of a remote contingency that will happen, if at all, in the distant future.

260 In many contexts, the further removed in time the breach is from the alleged harm, the more likely it is that a court would find the harm to be noncompensable on the grounds that it was either unforeseeable or too speculative to be proved. In addition, even if prejudgment interest is eventually awarded, in a situation where a non-breaching promisee does not have access to credit on reasonable terms during the pendency of the dispute, he may suffer large noncompensable harms as a result of the delay between breach and judgment.

261 However, this type of clause is only useful if the harm caused by the breach can be avoided or remedied through the cure provision.

262 In addition, in situations where it would be prohibitively expensive or simply impossible to draft a clause specific enough to reduce the risk and the amount the promisee would have to pay the promisor to assume the risk would make the transaction as a whole undesirable, these clauses can facilitate the conclusion of value- 
tion, by making it more likely that only efficient breach of contract will take place, these clauses can also increase social welfare. ${ }^{263}$

\section{Advantages of Specialized Providers}

When the dispute resolution provider is a trade association with its own transactional rules tailored to reflect industry custom, the inclusion of an arbitration clause in a contract enables the parties to contract with reference to a set of background rules and/or gapfilling provisions that are tailored to their business. This reduces the transaction costs of entering into a contract since fewer terms need to be specified. The ability to enter into contracts that will be interpreted and enforced in accordance with industry-specific norms will ordinarily be desirable from the perspective of the parties because small industries or closely-knit communities "will tend to develop for the ordinary run of problems norms that are wealthmaximizing." 264

Even in instances where a court would look to trade custom to decide a dispute, it is advantageous for the parties to contract for industry-specific arbitration. Unlike judges, many trade association arbitrators are drawn from the association's membership (or, most commonly, retired membership), and have extensive personal knowledge of industry custom. ${ }^{265}$ This gives them an advantage over judges, who must determine the content of customary norms from the conflicting testimony of expert witnesses. Arbitrators' industry-specific expertise and their authority to consider evidence that would be inadmissible at trial may make their verdicts more accurate and predictable than those of a court. As an arbitral tribunal acquires a reputation for consistency and as its judgments become increasingly predictable, the parties' view of the expected outcome of the proceeding will tend to converge, and more and

maximizing transactions that might not otherwise have been concluded.

263 These clauses also help mitigate the welfare loss from the socially excessive incentive to perform contracts that results when the damage caused by breach is likely to be high and what constitutes performance is unclear.

${ }^{264}$ Robert C. Ellickson, A Hypothesis of Wealth-Maximizing Norms: Evidence from the Whaling Industry, 5 J.L. ECON. \& ORG. 83, 84 (1989).

265 In the New York Diamond Dealers Club, for example, all arbitrators must be members of the club and are elected to the position for two-year terms. See DIAMOND Dealers Club, INC., ARBITRation By-LAWS, art. XII, §5a (1987). Some local CAA rules attempt to capture the benefits of arbitrator expertise by giving the parties a period of time to agree on the arbitrator of their choice. See supra note 28. 
more disputes will be settled without the assistance of a third-party neutral.

In general, when a dispute is likely to turn on technical questions of fact or specialized knowledge, ADR provisions requiring certain issues to be submitted to a technically skilled expert can create value by reducing both the likelihood of adjudicative error and the need for expensive provisions setting out the parties' obligations in highly specific contractual language. ${ }^{266}$

\section{Broadening the Range of Gredible Substantive Commitments}

Private ADR agreements can also broaden the range of credible substantive commitments available to the parties. In situations where a contract would be legally enforceable in theory but an action for breach would be prohibitively expensive, an agreement to use ADR can function as an "earnest of performance" in a manner similar to a liquidated damages provision. By giving the promisee the right to institute an action and obtain a recovery at a reasonable price, the promisor signals his intention to perform or pay damages. This is particularly important to new market entrants who lack an established reputation. Thus, in some situations, the availability of private ADR can facilitate entry into markets and improve competition.

\section{Enforcement Advantages}

The ability of courts and private ADR tribunals to enforce their judgments may differ substantially. Private (extralegal) dispute resolution tribunals are often preferred because they have the ability to impose both legal sanctions, such as money damages and specific performance, ${ }^{267}$ as well as extralegal sanctions. ${ }^{268}$ These extra-

${ }^{266}$ ADR provisions that designate an expert arbitrator to resolve certain types of disputes can be used as an effective substitute for contractual language where detailed provisions would have been needed to make the parties' obligations under the contract clear to a third-party neutral in the absence of the clause. In addition, in some contexts, ADR provisions can be used as partial substitutes for contractual language that is designed to clearly specify the parties' obligations so that the parties know what is required of them under the contract. See supra notes $257-63$ and accompanying text (discussing the use of an arbitrate and cure provision).

267 Unlike judges who are reluctant to order specific performance because they are unable to accurately assess compliance with their order, specialized arbitrators may have the expertise to monitor compliance with an order granting specific 
legal sanctions put additional pressures on the parties to comply with the arbitrated judgments, pressures that are unavailable to courts. For instance, in a well-organized industry, a trade association tribunal may be able to quickly translate an unpaid judgment into damage to reputation. ${ }^{269}$ Some trade associations and commodities exchanges require members to sign an agreement to submit disputes to the organization's dispute resolution tribunal and to promptly comply with their judgments. ${ }^{270}$ By threatening to expel a member or to publicize his failure to comply with a judgment rendered against him, these associations can make a credible threat to put a noncomplying disputant out of business. In the diamond industry, where all disputes among members of the world's diamond exchanges are decided by exchange-run mediation and arbitration tribunals, the existence and outcome of disputes are kept secret as long as the decisions of the dispute resolution tribunal are complied with, but a party who fails to promptly pay a judgment rendered against him will have his picture hung in every diamond exchange in the world along with a prominent notice

performance.

268 For a general discussion of extralegal sanctions, see Charny, supra note 101.

${ }^{269}$ Although an adverse court judgment can also harm a party's reputation, the harm may be greater when an intra-industry tribunal renders a decision because industry participants recognize its expertise and have greater confidence that the losing party actually violated industry-specific rules. The greater reputational effect of intra-industry arbitration was recognized by Judge Weinstein in AMF Inc. v. Brunswick Co., 621 F. Supp. 456 (E.D.N.Y. 1985), in which the court upheld an agreement to submit all disputes regarding truth-in-advertising claims to the National Advertising Division of the Council of Better Business Bureaus for a non-binding advisory opinion. The court noted that " $[\mathrm{v}]$ oluntary compliance with NAD's decisions has been universal ... [and] no advertiser who has participated . . . has declined to abide by the decision .... A court decision and a NAD decision would have different effects upon the parties' reputations within the bowling products industry." Id. at $458,463$.

270 See, e.g., DiAmond DEALERS CLUB, INC., BY-LAwS, art. III, § $2 \mathrm{~b}$ (1980) (“It shall be a condition of membership ... [to] be bound by and be subject to the mandatory arbitration provisions contained in these by-laws."). Similarly, the Chicago Mercantile Exchange rules provide:

[I]t is contrary to the objectives and policy of the Exchange for members to litigate disputes relating to or arising out of any transaction upon the Exchange or membership in the Exchange... . [A] person or entity elected to membership agrees to have any disputes which ... relate to or arise out of any transaction upon the Exchange or membership in the Exchange resolved in accordance with the [arbitration] rules contained herein.

Consolidated Rules of THE CHICAGo MERCANTILE EXCHANGE AND THE INTERNATIONAL MONETARY MARKET DIVISION AND THE INDEX AND OPTION MARKET DIVISION R. 600(A), (B) [hereinafter CHICAGO MERC. RULES]. 
describing his wrongdoing and the fact that he failed to pay a judgment. ${ }^{271}$ At the Chicago Mercantile Exchange, where the mere existence of a dispute can threaten the public's perception of the integrity of the market, both the existence of a dispute and the judgment of the Exchange's dispute resolution tribunal are posted outside the trading floor even when the guilty party promptly pays the judgment rendered against him. ${ }^{272}$ Although exchange rules limit the maximum fine that can be imposed, ${ }^{273}$ the reputational effect of making the dispute and judgment public greatly increases the significance of the sanction.

A court-appointed arbitrator, in contrast, cannot take advantage of these types of extralegal enforcement mechanisms; he cannot bring any unique pressures to bear on the parties to induce them to accept his decision, and the fact that he has rendered a decision may have no more effect on the parties' reputations than the mere filing of a claim.

In sum, the private benefits available from the inclusion of private ADR provisions go far beyond the ex post reduction in delay and dispute resolution costs. When the parties are able to agree on an acceptable neutral, narrowly tailored ADR provisions may reduce the costs of entering into a contract and can be used to reduce the actual damage suffered by the promisee in the event of breach and thereby increase the value of a contractual promise. In addition, such clauses can broaden the range of credible contractual commitments available to the parties and, in certain contexts, can be used to secure enforcement advantages and the full benefit of reputation bonds. While some of these gains can be captured through the use

271 See Bernstein, supra note 242, at 128. In general, the use of secrecy as a "carrot" and publicity as a "stick" is a common feature of trade association dispute processing procedures. For example, the National Advertising Division of the Council of Better Business Bureaus ("NAD") requires the dispute to be kept secret until it is resolved and, under its procedural rules, the organization may "refuse to handle a case where the challenger [plaintiff] publicizes, or otherwise announces, to third parties not directly related to the case the fact that specific advertising is being referred to NAD for resolution." NATIONAL ADVERTISING DIV., COUNCIL OF BETTER Business BUREAUS, INC., NATIONAL AdVERTISING REview BOARD Procedures $\S 2.2(B)(v)(1991)$; see also Self-Regulation: Neutral Forum for Advertisers, 9 ALTERNATIVES 69, 73 (1992) (discussing NAD procedures). This provision can also be viewed as an attempt to prevent parties from using the NAD process to place a de facto cloud on title on a competitor's advertising claim.

272 See 17 C.F.R. $\$ 9.13$ (1992) (requiring the posting of disciplinary findings in a "conspicuous" place for five consecutive business days).

273 See ChICAgo MERc. Rules, supra note $270, \S 430$ (describing maximum penalties for major and minor violations of exchange rules). 
of private ex post ADR agreements, they cannot, for the most part, be captured by requiring parties to participate in a non-binding GAA hearing conducted by a volunteer member of the local bar. Thus, evidence of the popularity and success of private, consensual, binding ADR should not be used to justify mandatory non-binding court-annexed arbitration programs, and should be used with caution in analyzing the desirability of other types of court-connected ADR programs.

\section{The Potential Uses of Private ADR to Increase the Value of Traditional Adjudication}

Although the analysis presented here suggests that the government should not become a provider of mandatory non-binding CAA programs, and that many of the benefits of private ADR cannot be fully replicated in court-connected ADR programs, this does not necessarily mean that ADR cannot be used to increase access to justice by helping to solve some of the problems created by the high cost and long delays in civil litigation. ${ }^{274}$ Another possible approach to using ADR to help solve the problems facing the federal courts, would be to amend the Federal Rules of Civil Procedure to explicitly permit parties to use private $A D R$ in place of or in conjunction with certain pre-trial procedures, ${ }^{275}$ and to ensure the

274 The suggestions made in this section are designed to increase access to justice (defined as increasing the likelihood that a plaintiff who suffers $\$ X$ in damages will recover an amount as close as possible to $\$ X$, net of litigation costs) by reducing the private cost (that is, the cost to the parties) of obtaining a judicial resolution of their dispute. The effect of such proposals on the social cost of litigation and the number of trials held is more difficult to predict. As the cost of traditional adjudication decreases, the number of cases filed may increase. More claims will have a positive expected value, and some disputes that would otherwise have been resolved through private ADR may now be resolved in court. Alternatively, increasing the pace and decreasing the cost of discovery might lead to earlier settlements. For a formal analysis of the likely effects of the availability of bifurcated trials or sequential decisions on separate issues on parties' litigation decisions and the number of suits filed, see William A. Landes, Sequential Versus Unitary Trials: An Economic Analysis, 22 J. LEGAL STUD. 99 (1993).

275 For example, the parties might enter into an agreement to submit all discovery disputes to a binding determination by a third-party neutral. Alternatively, they might designate a discovery "wise man" who, in the event of a dispute, will determine, either with or without a hearing, the information each party will have to produce. The use of such a "wise man" will greatly limit a party's ability to impose large costs on his opponent by making unnecessary discovery requests. 
legal enforceability of ADR provisions ${ }^{276}$ and other types of agreements ${ }^{277}$ designed to reduce the cost of trial. Such an approach would create private benefits by reducing the cost of traditional adjudication, and might also create social benefits by enabling judges to spend more time deciding questions of law. If private ADR agreements could be used in this manner, they would have the potential to create value not only by enabling parties to opt out of the law, but also by enabling them to leverage the law, that is, to contract for the mix of private and public dispute resolution and dispute avoidance techniques ${ }^{278}$ best suited to their transaction. ${ }^{279}$

${ }^{276}$ For example, if, in the event of a dispute, a court would have to permit the introduction of extensive, and in most cases conflicting, expert testimony to resolve a highly technical question of fact, the parties could include a provision in their contract requiring that the issue be submitted to a technically skilled arbitrator whose determination would be considered binding in any subsequent litigation. This would have the additional benefit of increasing the accuracy and predictability of the trial outcome, which would, in turn, narrow the settlement range and may make settlement more likely. In addition, in some types of disputes this type of provision may make it possible to resolve the dispute on summary judgment, which is much quicker and cheaper than a trial, but still enables the parties to get a judicial determination on questions of law.

${ }^{277}$ For example, in cases where the dispute would likely turn on questions of industry custom, but industry-specific arbitration is not readily available, the parties might enter into an agreement specifying that in the event of litigation, a particular expert will be the only person allowed to testify about the content of industry norms.

278 There are some types of ADR processes and provisions that are more accurately described as alternative dispute avoidance techniques. See, e.g, supra note 275 (describing the use of a discovery "wise man" who determines which documents each side must produce in the event of a dispute); supra notes 261-63 and accompanying text (describing the use of arbitrators to obtain a declaratory judgment-for example, in a contract setting, a determination that a particular action will or will not constitute breach of contract-that would be binding in any subsequent litigation).

279 The recognition that many of both the private and social benefits of ADR can only be fully realized when ADR agreements are entered into ex ante, that is, before a dispute arises, suggests that in jurisdictions that operate Multidoor Courthouses or in jurisdictions that use a differentiated case management system where, after an initial intake conference, a case is routed to one of several "tracks"-each associated with a distinct set of pre-trial procedures-the programs' ability to create value for the parties would be enhanced if parties could elect via a choice of procedure provision in their contract to submit all disputes that might arise to the track of their choice. For a more formalized discussion of the differences between ex ante and ex post ADR, see Steven Shavell, Alternative Dispute Resolution: An Economic Analysis (July 1993) (Harvard Law School Program in Law \& Economics, Discussion Paper No. 131) (unpublished manuscript, on file with the author). 


\section{CONCLUSION}

This Article has focused primarily on the desirability of one form of federal court-connected ADR-mandatory non-binding court-annexed arbitration-but it has also provided a framework that can be extended to analyze the promise of other types of courtconnected ADR such as mini-trials, mandatory mediation, summary jury trials, and early neutral evaluation. ${ }^{280}$ The numerical simulations of parties' litigation decisions in a CAA jurisdiction with a post-arbitration fee and cost-shifting provision and the discussion of the real world factors not captured in the simulations have suggested that CAA programs have distributional effects that are often overlooked by legislators who draft CAA enabling legislation, judges who draft local rules implementing the programs, and academics who evaluate the programs' desirability on both theoretical and empirical levels. Finally, the exploration of the differences between private and public ADR has demonstrated that public ADR programs cannot capture most of the benefits available from private ADR that lead parties to either include ADR provisions in their contracts or enter into agreements to use ADR after a dispute has arisen.

Although the cost and delay involved in civil litigation continue to increase and impede access to justice, CAA programs will not increase access to justice and may in fact decrease access to justice for poorer and more risk-averse litigants by either adding an additional layer of costly procedure or, in programs with postarbitration fee and cost-shifting provisions, by forcing them to take more risk. The analysis presented here suggests that further experimentation with federal court-annexed arbitration is unwarranted since the programs will produce neither private nor social benefits.

280 The analysis presented here has also suggested that in considering the desirability of public ADR programs in the federal courts, such programs should be viewed as a bundle of procedural reforms and analyzed as innovations in pre-trial procedure rather than as substitutes for trial or alternative forms of dispute resolution.

Supporters of CAA fail to realize that despite the name "court-annexed arbitration," the dominant feature of most federal CAA programs is not the so-called arbitration hearing itself. Rather, the programs are more accurately viewed as a bundle of procedural reforms relating to discovery limits, fee and cost-shifting, and other aspects of case management. Viewing the arbitration hearing as the most important program feature has led CAA proponents to contend that any shortcomings in CAA programs can be overcome by improving the quality of arbitrators and the amount of information revealed at the arbitration hearing. However, the discussion presented here suggests that this is not the case. 


\section{TECHNICAL APPENDIX}

\section{NOTATION}

$V a$ is the probability of an arbitration award in favor of the plaintiff and $V t$ is the probability of a trial verdict in favor of the plaintiff.

$A^{*}$ and $T^{*}$ are the expected arbitration award and the expected trial judgment, respectively, if the plaintiff prevails. Let $f(A)$ and $g(T)$ be the distributions of arbitrated and trial outcomes if the plaintiff prevails. The outcomes are assumed to be normally distributed.

$C p$ and $C d$ are the plaintiff's and defendant's pre-arbitration costs. $C p^{\prime}$ and $C d^{\prime}$ are the plaintiff's and defendant's post-arbitration costs. Costs include attorneys' fees as well as the expenses that can be recovered under 28 U.S.C. $\S 1920$ (1988); they are assumed to be determined exogenously.

$S p$ is the probability that if the plaintiff alone requests a trial, he will fail to improve his position by $15 \%$ at trial $(A+.15 A>T)$ and will therefore suffer a cost-shifting sanction and have to pay the defendant's post-arbitration costs, $C d^{\prime}$.

$S d$ is the probability that if the defendant alone requests a trial, he will fail to improve his position by $15 \%$ at trial $(A-.15 A<T)$ and will therefore suffer a cost-shifting sanction and have to pay the plaintiff's post-arbitration costs, $C \boldsymbol{p}^{\prime}$.

$\hat{A}$ represents an actual arbitration award that has been rendered.

\section{THE MODEL}

Suppose that an arbitration has taken place and that an award $\hat{A}$ has been rendered in the plaintiff's favor. In deciding whether or not to request a trial, the plaintiff will compare his expected posttrial position when he alone requests a trial to his post-arbitration position, and will request a trial only when the former is more favorable. The plaintiff's post-arbitration position is $\hat{A}-C p$. His expected post-trial position is:

$$
\text { Eq. IP } \quad V t\left[T^{*}-S p C d^{\prime}-C p^{\prime}\right]-(1-V t)\left(C d^{\prime}+C p^{\prime}\right)-C p
$$

Consequently, a risk-neutral plaintiff will request a trial when:

$$
V t\left[T^{*}-S p C d^{\prime}-C p^{\prime}\right]-(1-V t)\left(C d^{\prime}+C p^{\prime}\right)>\hat{A}
$$


Thus, the award $A$ such that:

Eq. $2 P \quad V t\left[T^{*}-S p C d^{\prime}-C p^{\prime}\right]-(1-V t)\left(C d^{\prime}+C p^{\prime}\right)=A$

is the critical point for the plaintiff, denoted Acp, above which it will always be rational for him to accept the arbitration award and below which it will always be rational for him to request a trial.

When the plaintiff alone requests a trial, the plaintiff's expected gain from going to trial is:

Eq. $3 P$

$$
V t\left[T^{*}-S p C d^{\prime}-C p^{\prime}\right]-(1-V t)\left(C d^{\prime}+C p^{\prime}\right)
$$

The defendant's expected loss is:

Eq. $4 P$

$$
\begin{aligned}
& V t\left[T^{*}+(1-S p) C d^{\prime}\right]+(1-V t)(0)= \\
& V t\left[T^{*}+(1-S p) C d^{\prime}\right]
\end{aligned}
$$

Similarly, once an arbitration award has been rendered in favor of the plaintiff, the defendant too must decide whether to request a trial. To do so he will compare his post-arbitration position, $\hat{A}+$ $C d$, to his expected post-trial position when he alone requests a trial. His expected post-trial position is:

Eq. $1 D$

$$
V t\left[T^{*}+S d C p^{\prime}+C d^{\prime}\right]+(1-V t) C d^{\prime}+C d
$$

Consequently, a risk-neutral defendant will request a trial when:

$$
V t\left[T^{*}+S d C p^{\prime}+C d^{\prime}\right]+(1-V t) C d^{\prime}<\hat{A}
$$

Thus, the award $A$ such that:

Eq. $2 D$

$$
V t\left[T^{*}+S d C p^{\prime}+C d^{\prime}\right]+(1-V t) C d^{\prime}=A
$$

is the critical point for the defendant, denoted Acd, above which it is always rational for the defendant to request a trial and below which it is always rational for him to accept the arbitration award.

When the defendant alone requests a trial, the defendant's expected loss from going to trial is:

Eq. $3 D$

$$
V t\left[T^{*}+S d C p^{\prime}+C d^{\prime}\right]+(1-V t) C d^{\prime}
$$


The plaintiff's expected gain is:

Eq. $4 D$

$$
V t\left[T^{*}-(1-S d) C p^{\prime}\right]-(1-V t) C p^{\prime}
$$

When the arbitration award falls above $A c p$ and below $A c d$, a range referred to in the text as the "dead zone," in the absence of strategic behavior, ${ }^{281}$ each party, comparing his post-arbitration position to his expected post-trial position, prefers to accept the arbitration award regardless of what his opponent decides to do. The plaintiff will reason that if the defendant decides not to request a trial, he too is better off not requesting one since the award lies to the right of $A c p$, which is, by definition, the award above which the plaintiff's expected post-trial position, if he alone requests a trial, is less advantageous than his post-arbitration position. And, if the defendant does request a trial, the plaintiff is still best off not requesting a trial since when the defendant alone requests a trial there is some chance that the plaintiff will not have to bear his own costs, whereas if both parties request a trial each bears his own costs regardless of the outcome. Similarly, the defendant will reason that if the plaintiff decides not to request a trial, he too is better off not requesting one since the award is to the left of $A c d$, which is, by definition, the award below which the defendant's expected posttrial loss, if he alone requests a trial, is greater than his post-arbitration loss if he pays the arbitration award. And, if the plaintiff does request a trial, the defendant is still best off not requesting a trial since, if the plaintiff alone requests a trial, there is some chance that he (the defendant) will not have to pay his litigation costs, whereas if they both request a trial each will bear his own costs regardless of the outcome. Thus, in the world of the model, the decision of both parties to accept the arbitration award when it falls in the dead zone is a Nash equilibrium. ${ }^{282}$

${ }^{281}$ In reality, however, parties routinely reject settlement offers that are more advantageous than their expected post-trial positions in the hope that they will be able to capture a larger share of the bargaining surplus. Consequently, a party may also compare $\hat{A}$ to the most favorable post-trial de novo request settlement amount that he expects his opponent to accept. Thus, particularly when one side has superior bargaining power, a trial may be requested even when the arbitration award falls in the dead zone. The model therefore tends to overstate the probability that the arbitration award will be accepted by both parties as a final resolution of their case. See supra note 229.

${ }_{282}$ However, as the simulations of divergent expectations and mutual pessimism suggest, when the parties have different views about their probability of prevailing or the amount the plaintiff will recover if he prevails, it is possible that a dead zone will 
It is now necessary to consider what happens if the arbitrator rules in favor of the defendant. In such a case it is clear that the defendant will never request a trial. The plaintiff, however, will request a trial as long as his expected gain from doing so is greater than zero, that is, if:

$$
\text { Eq. 4.5P } \quad V t\left[T^{*}-C p^{\prime}\right]-(1-V t)\left(C p^{\prime}+C d^{\prime}\right)>0
$$

In such a situation the plaintiff's expected gain from requesting a trial is:

$$
\text { Eq. } D P 1 \quad V t\left[T^{*}-C p^{\prime}\right]-(1-V t)\left(C p^{\prime}+C d^{\prime}\right)
$$

And, the defendant's expected loss is:

$$
\text { Eq. } D P 2 \quad V t\left[T^{*}+C d^{\prime}\right]+(1-V t)(0)=V t\left[T^{*}+C d^{\prime}\right]
$$

Having established the conditions under which each party would request a trial after an arbitration award has been rendered, it is possible to compute the plaintiff's expected gain, and the defendant's expected loss, at the outset of the litigation process in a CAA jurisdiction, and to compare it to the parties' expected gains and losses at the outset of the litigation process in a trial-only jurisdiction.

In a trial-only jurisdiction with the American Rule, ${ }^{283}$ the plaintiff's expected gain is:

$$
\text { Eq. } 5 P \quad V t\left[T^{*}\right]-C p-C p^{\prime}
$$

The defendant's expected loss is:

$$
E q .5 D
$$

$$
V t\left[T^{*}\right]+C d+C d^{\prime}
$$

In a CAA jurisdiction, in order to compute their expected gains and losses at the outset of the litigation process, the parties will have to calculate their expected positions in four situations which occur with the following probabilities:

not exist.

${ }^{283}$ Under the American Rule, each side bears its own costs regardless of the outcome. 
(1) The arbitrator rules for the defendant, which occurs with the probability 1 - $V a$, and the plaintiff requests a trial;

(2) The arbitrator rules for the plaintiff and renders an award $\hat{A}<A c p$ so that the plaintiff requests a trial, which occurs with probability: ${ }^{284}$

prob1

$$
V a \int_{-\infty}^{A c p} f(A) d A
$$

(3) The arbitrator rules for the plaintiff and renders an award $\hat{A}>A c d$ so that the defendant requests a trial, which occurs with probability: ${ }^{285}$

prob2

$$
V a \int_{A c d}^{\infty} f(A) d A
$$

(4) The arbitrator rules for the plaintiff and renders an award $\hat{A}$ that is $A c p<\hat{A}<A c d$, which occurs with probability:

prob3

$$
V a \int_{A c p}^{A c d} f(A) d A
$$

in which case neither party requests a trial and the arbitration award is entered as the judgment of the court.

For each of these scenarios, the parties must compute their expected position if the plaintiff wins at trial, which occurs with probability $V t$, and if the plaintiff loses at trial, which occurs with probability $1-V t$.

Thus, in a CAA jurisdiction, at the outset of the litigation process, the plaintiff's expected gain from trial is:

Eq. $P G$

$$
\begin{aligned}
& (1-V a)\left[V t\left(T^{*}-C p^{\prime}\right)-(1-V t)\left(C p^{\prime}+C d^{\prime}\right)\right]+ \\
& V a\left[\left(\int_{-\infty}^{A c p} f(A) d A\right)\left[V t\left(T^{*}-S p C d^{\prime}-C p^{\prime}\right)-(1-V t)\left(C p^{\prime}+C d^{\prime}\right)\right]\right]+
\end{aligned}
$$

$$
\begin{aligned}
& V a \int_{A c p}^{A c d} A f(A) d A+ \\
& V a\left[\left(\int_{A c d}^{\infty} f(A) d A\right)\left[V t\left(T^{*}-(1-S d) C p^{\prime}\right)-(1-V t)\left(C p^{\prime}\right)\right]\right]-C p
\end{aligned}
$$

284 For computational reasons, the simulations use the integral from zero to Acp.

285 For computational reasons, the integral from Acd to two million is used. The integrand two million was chosen since this is the largest arbitration award ever rendered in a CAA jurisdiction. 
Similarly, in a CAA jurisdiction, the defendant's expected loss at the outset of the litigation process is:

$$
\begin{aligned}
& (1-V a)\left[V t\left(T^{*}+C d^{\prime}\right)-(1-V t)(0)\right]+ \\
& V a\left[\left(\int_{-\infty}^{A c p} f(A) d A\right)\left[V t\left(T^{*}+(1-S p) C d^{\prime}\right)+(1-V t)(0)\right]\right]+ \\
& V a \int_{A c p}^{A c d} A f(A) d A+ \\
& V a\left[\left(\int_{A c d}^{\infty} f(A) d A\right)\left[V t\left(T^{*}+S d C p^{\prime}+C d^{\prime}\right)+(1-V t)\left(C d^{\prime}\right)\right]\right]+C d
\end{aligned}
$$

$E q . D L$ 
